VOICE SOLO with



18 


\section{VOICE SOLO with}

\section{PIANO \& CHORUSES} for

\section{T.T.B.B.}

BY

JOSHUA A. AMUAH

\section{(9)Noyam}

PUBLISHERS

Accra, Ghana 


\section{THIS COPY IS NOT FOR SALE}

\section{Voice Solo with Piano and Choruses for T.T.B.B}

JOSHUA ALFRED AMUAH

Copyright (C) 2020 Noyam Publishers

ISMN 979-0-9008043-0-3

DOI: $10.38159 /$ npub.eb20504

Published in Ghana by Noyam Publishers

Typeset in Finale by Joshua Alfred Amuah and Kofi Labayili Kudonu

Cover by Triple M Grafix

All rights reserved.

No part of this publication may be reproduced

or transmitted in any form or by any means, electronic or mechanical,

including photocopying, recording, or any information storage

and retrieval system, without permission in writing from the publisher.

For further information or permission,

Contact:

Noyam Publishers

P.O. Box $165 \mathrm{La}$,

Accra-Ghana

Contact Number: +233 593142920

Email: publications@noyam.org

Website: www.noyam.org 
To the Glory of God

And

My Voice Students 


\section{Acknowledgements}

I am indeed indebted to Mr. Charles Bernard Wilson of Cape Coast, who nurtured my life as an academic musician. He picked me up from nowhere and encouraged me to come this far. I am equally grateful to colleague lecturers in the Department of Music, University of Ghana, Legon, particularly Dr. Benjamin AmakyeBoateng and Mr. Kofi Labayili Kudonu who assisted me in the use of finale for this work.

I am likewise thankful to Mr. Kojo Frimpong of Sirmax Music Consult who assisted me in the formatting of this work anytime I called on him.

I greatly acknowledge the support which I received from Dr. Hilarius Mawutor Wuaku, a lecturer in the Department of Music, University of Ghana, Legon, who doubles as the Artistic Director of Abibigromma Resident Theatre Company of the School of Performing Arts, University of Ghana, for proofreading the entire book.

I also acknowledge the assistance I have enjoyed from my voice students who insisted on being the first to perform the pieces as part of their semester requirement. Also to Triple M. Grafix for doing the camera ready work after designing the cover of the book. In fact, he has been selfless, and has always attended to my requests promptly, no matter the time I called on him.

Finally, to my other colleague lecturers at the Department of Music, University of Ghana, Legon with Dr. Adwoa Arhine as the torch bearer, Mr. Timothy E. Andoh, the grandpapa and Prof. John Collins, the great grandpapa who all in diverse ways have contributed to the success of this book. To all those whose names I have not mentioned I say thank you and may God bless you richly. 


\section{Table of Contents}

Dedication

iv

Acknowledgement

$\mathrm{V}$

Table of Content

vi

Foreword

vii

Preface

viii

I. Bone Ben? (What Crime?)

2. Jbobo adze (It will come to an end)

3. Bom' nantsew (Lead me on)

4. Nkotwa du (You won't score ten)

5. M'beda Nyame ase (I will render thanks unto God)

6. Me Nyame bra o! (Come! My God)

7. Buebue Sor ntokura (Open the windows of Heaven)

8. Womma yenkıdo nsom Ewuradze

9. Bone Ben? (What Crime) 


\section{THIS COPY IS NOT FOR SALE}

\section{Foreword}

I am happy to write the forward for this score book as I have had a long academic relation with Dr. Amuah, as in the late 1990s he was one of my graduate students at the University of Ghana's Music Department at Legon, and then much later I worked under him when he was Head of that Department. I also helped edit the articles he did for some of the publications of the University of Ghana's School of Performing Arts, such as its Journal of Performing arts (JPA) that I was editor of, from 2009 to 2015. We also both worked together providing information for the Musicians Union of Ghana (MUSIGA) 2015, report on the Ghanaian music industry entitled 'A Comprehensive Study of the Music Sector'; with Dr. Amuah suppling information and data on choral music and myself, information on local popular music.

Since 1998, Dr. Amuah has been the choirmaster and organist at the 37 Military Hospital Methodist/ Presbyterian Church, and in 2002 he became the $2^{\text {nd }}$ Deputy National Director of Music of the Association of Methodist Church Choirs of Ghana, becoming its $1^{\text {st }}$ Deputy National Director of Music in 2004. From 2008 to 2012 he was Director of Music of the Association of Security Church Choirs and then went on to become its Vice President.

Dr. Joshua Alfred Amuah's Voice Solo and Piano with Choruses for Male Choirs (TTBB) is significant in two major ways. In addition to proffering teachers and lecturers in secondary and tertiary institutions, this book becomes an authentic resource material in those academic levels.

Books and other instructional materials on Solo pieces especially on voice exist, the texts of which are in English. Apart from the efforts made by Ephraim Amu and Joseph H. K Nketia in the writing of solo pieces, none exists in Ghana. Over the years, students, teachers and lecturers have over relied on the pieces composed by these two giants in Ghanaian musicology. The pieces have been sung repeatedly and seem no more to be beautiful. Therefore, it is appropriate, and timely for Dr. Amuah to intervene with new set of solo pieces, to augment the existent ones in order to create a variety. The pieces will address some of the social, religious and political issues in Ghana. This book therefore becomes very apt in this regard.

In this book, Dr. Amuah presents seven (7) solo pieces for voice, and two (2) choruses for male choirs some of which are already test pieces for the West African Examinations Council for the use of Senior High Schools. Universities in the country have equally relied on some of the pieces for their voice students.

It is with great pleasure that I strongly recommend this solo songbook to teachers, lecturers and students at all levels of educational institutions in Ghana and other parts of Africa.

\section{Prof. John Collins,}

Professor of Music,

Department of Music,

University of Ghana, Legon. 


\section{THIS COPY IS NOT FOR SALE}

\section{Preface}

Voice Solo with Piano and $1^{\text {st }}$ Tenor, $2^{\text {nd }}$ Tenor, $1^{\text {st }}$ Bass, $2^{\text {nd }}$ Bass (T.T.B.B) choruses is a product of so many years of singing as a student, teacher and examiner for both local and international examination bodies. The book is intended to fill the gap that exists due to a lack of solo pieces for those studying voice as a major instrument at all levels in the Ghanaian educational set up.

Growing up as a musician, voice was and continues to be my principal instrument. In the course of performances, I realised that there was a limitation of pieces to perform. Pieces available were composed by the two giants in Ghanaian musicology; Ephraim Amu and Joseph Hanson Kwabena Nketia, both of blessed memory. Their pieces have been over depended, such that they have nearly lost their beauty.

This book of Voice Solo with Piano and Choruses for T.T.B.B, has seven solo works accompanied by the piano with two choruses for male choirs, pieces that are also scarce because of the unavailability of such choirs.

The text of the pieces have been drawn from inspiration, partly from occurrences in our routine social activities, and arrangements form existing works for choral groups. Out of the seven solo pieces, three are secular ones, which relate to our daily mundane events, and four are sacred reflecting my inclination to the work of God. Two out of the four are arrangements from Ebibindwom pieces which have been designated for S.A.T.B by Isaac Daniel Riverson and Michael Amissah respectively. The two choruses for male choir are shared among our daily routine activities and the work of God.

Although the book is primarily for use by students in Senior High Schools and Universities it would be found particularly useful by performers who want to stage a concert. Secular pieces are uncommon in our part of the world and it is about time we begin to write and popularise them.

\section{Joshua Alfred Amuah, Ph.D}

Department of Music,

School of Performing Arts (SPA),

University of Ghana, Legon. 


\section{BDNE BEN? \\ (What Crime?)}

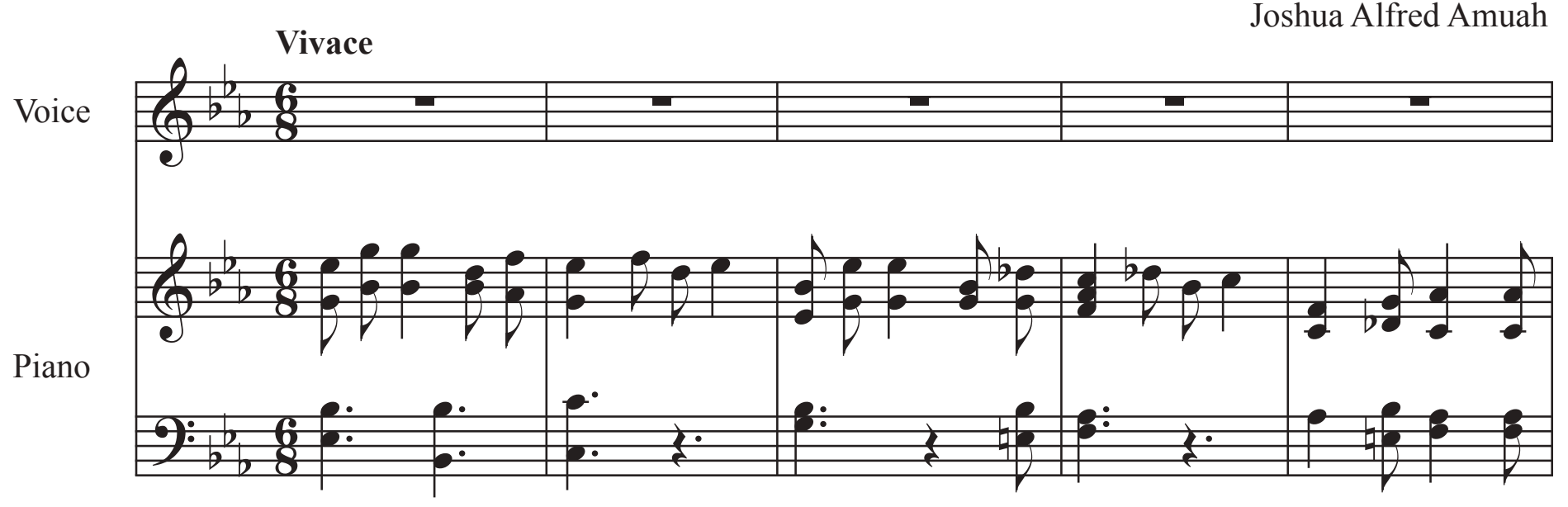

Joshua Alfred Amuah 

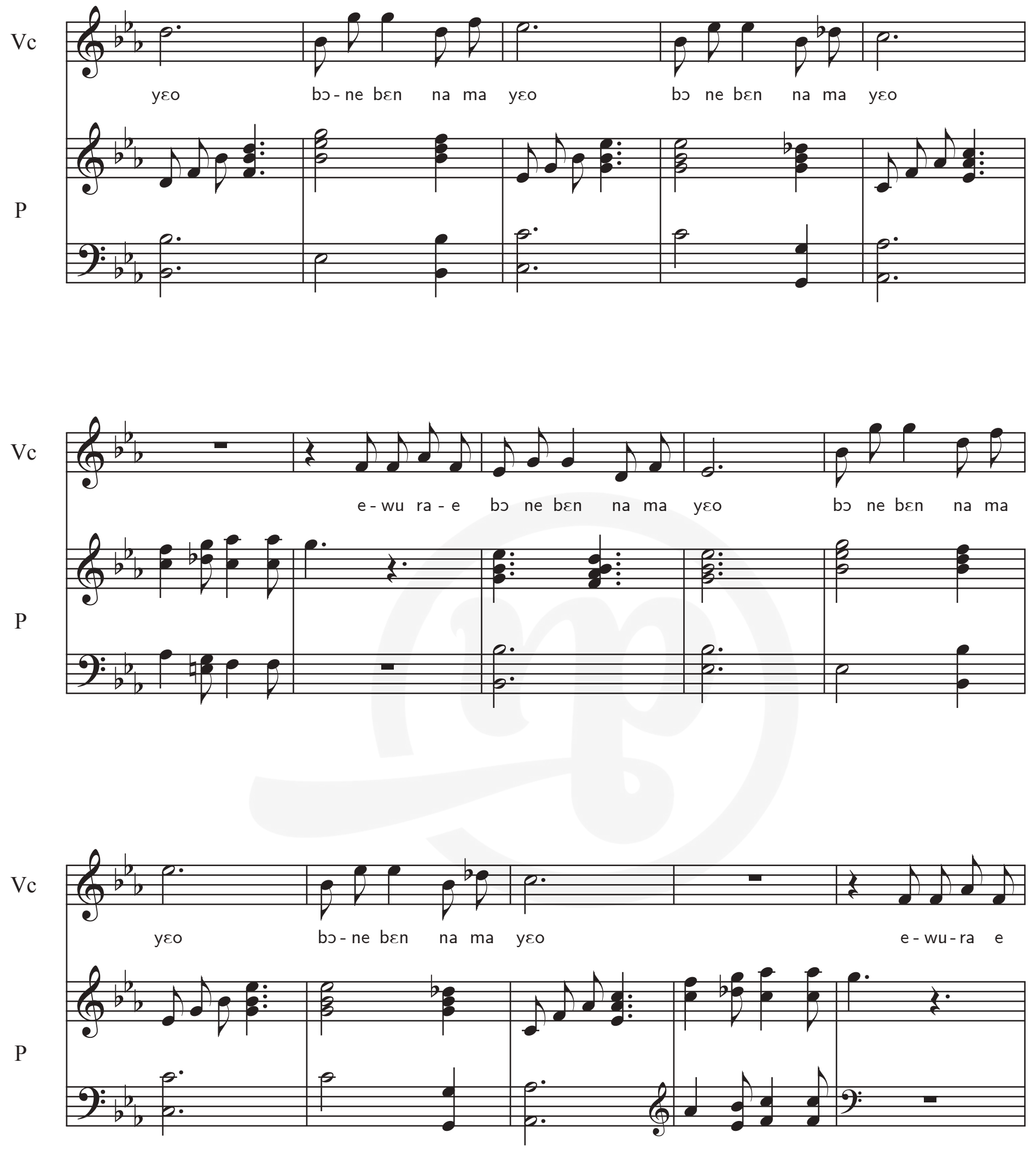
$\mathrm{Vc}$

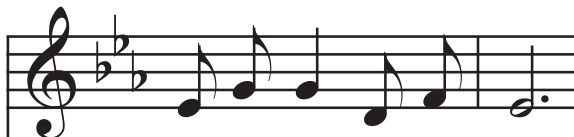

bว-ne ben na ma yeo
: (a)

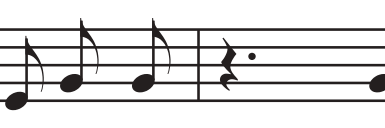

bว-ne ben?

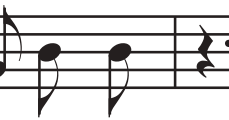

bo-ne ben?

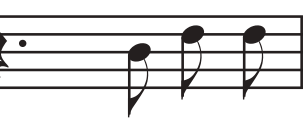

bo-ne ben

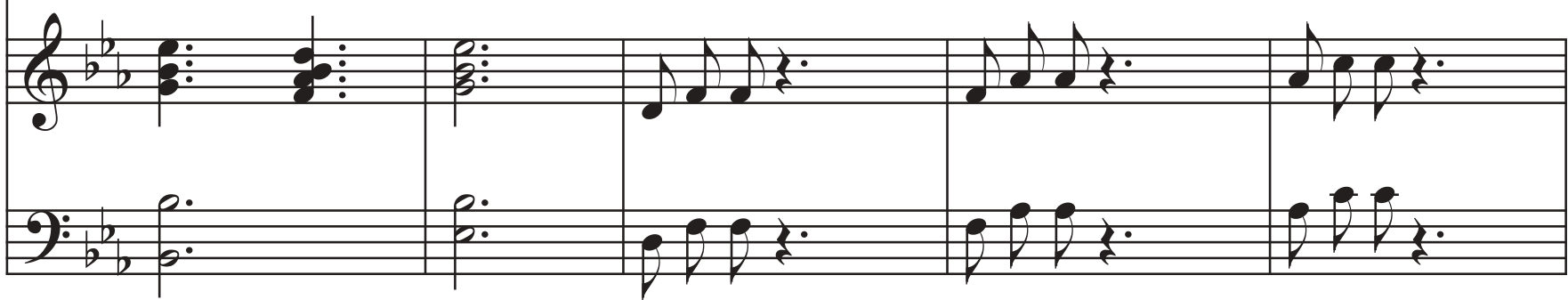

$\mathrm{Vc}$

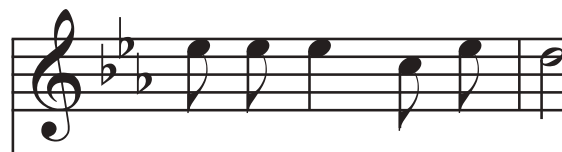

bo-ne ben na ma yeo

$\mathrm{P}$

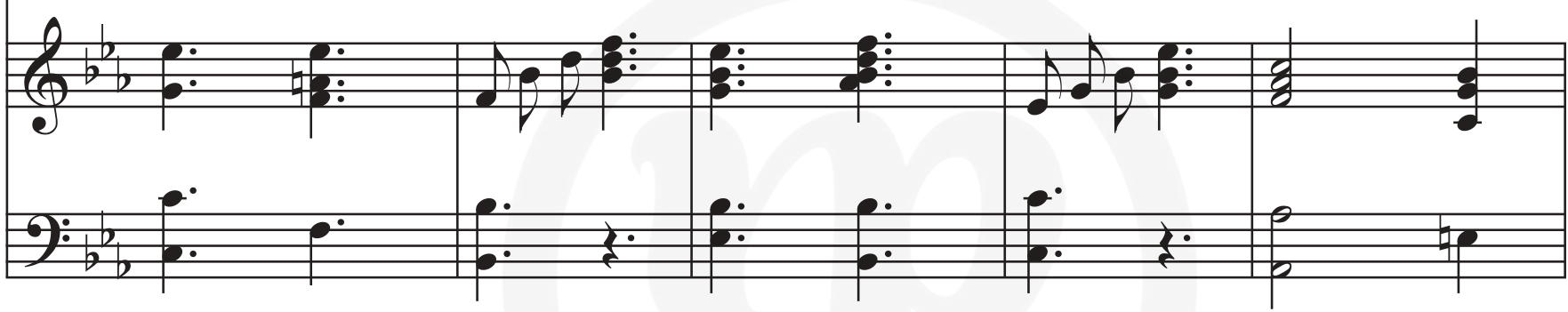

$\mathrm{Vc}$
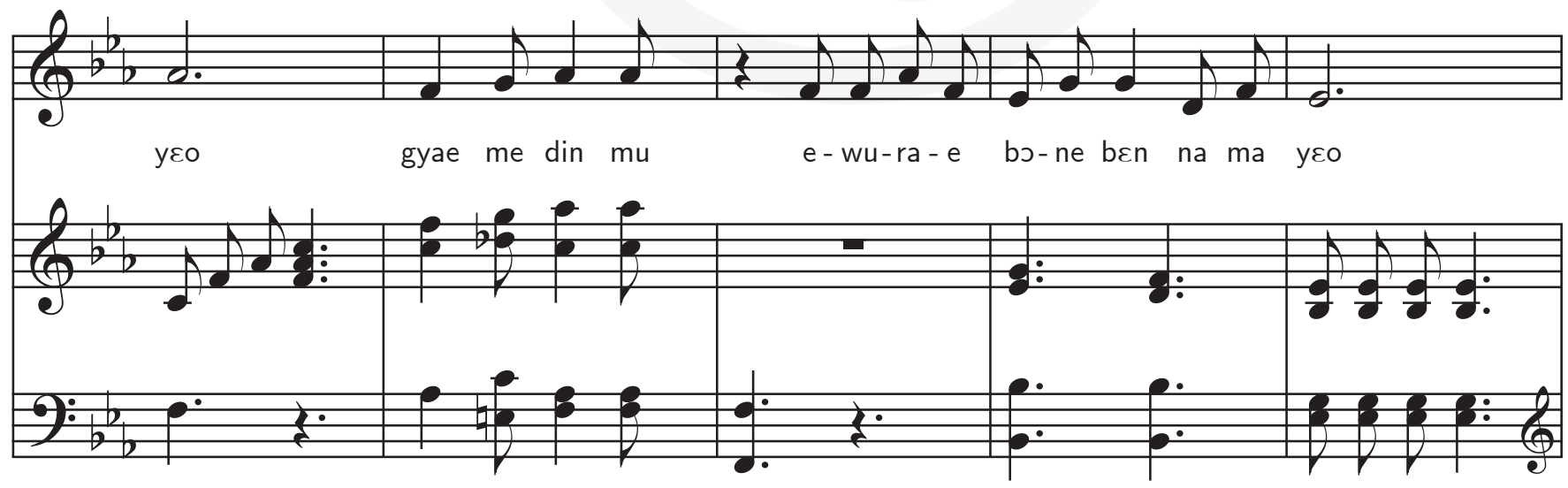

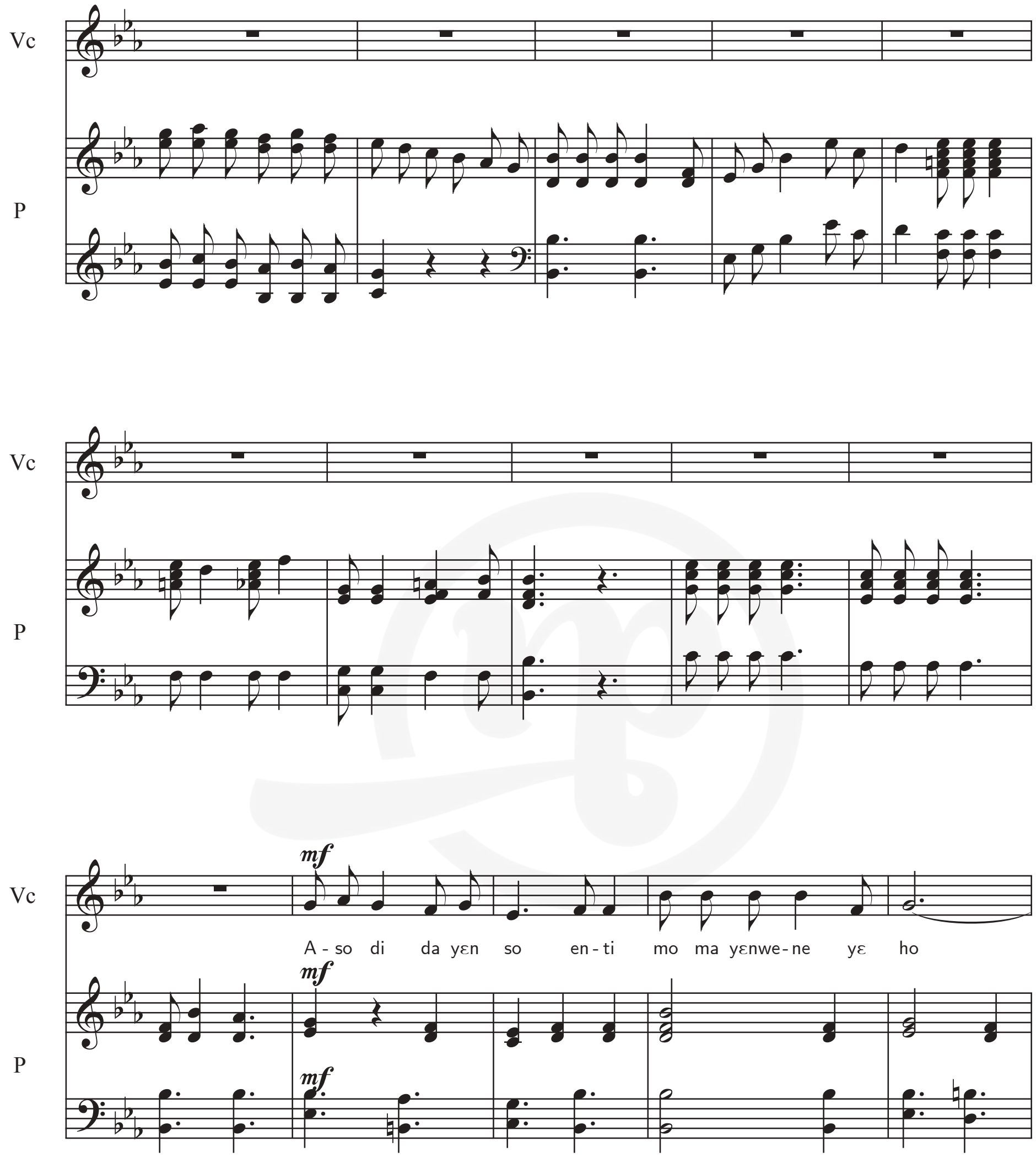
$\mathrm{Vc}$
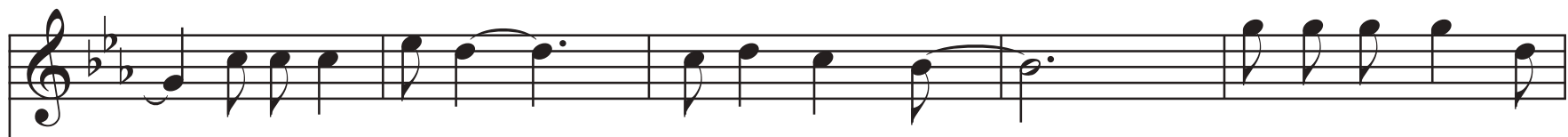

a-ke-ka - ke kae $\quad \varepsilon m-f a$ hwee mmao

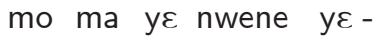

$\mathrm{P}$

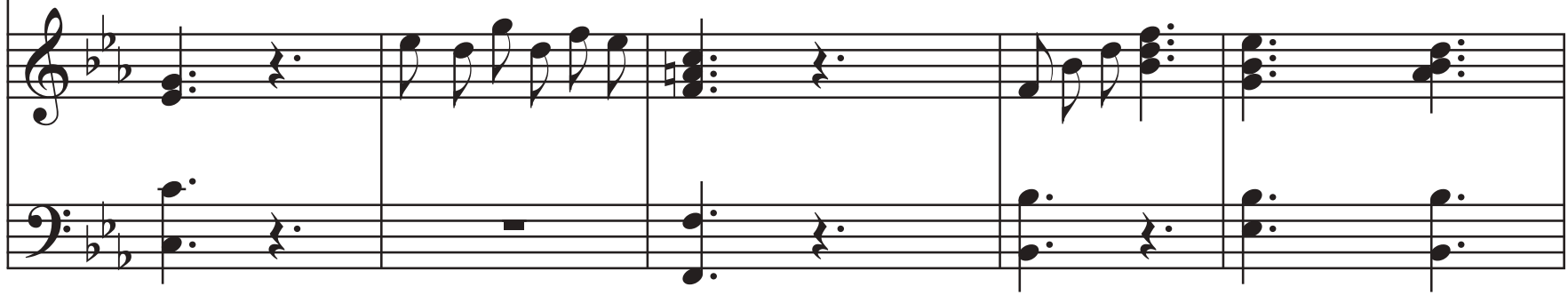

$\mathrm{Vc}$
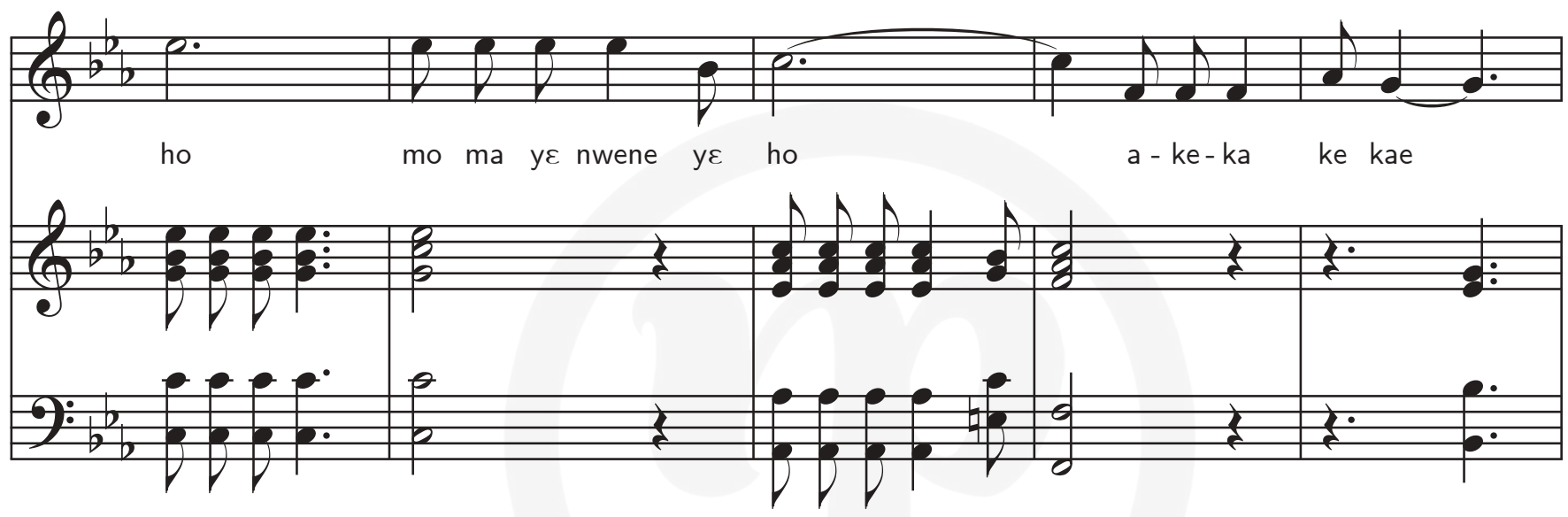

$\mathrm{Vc}$

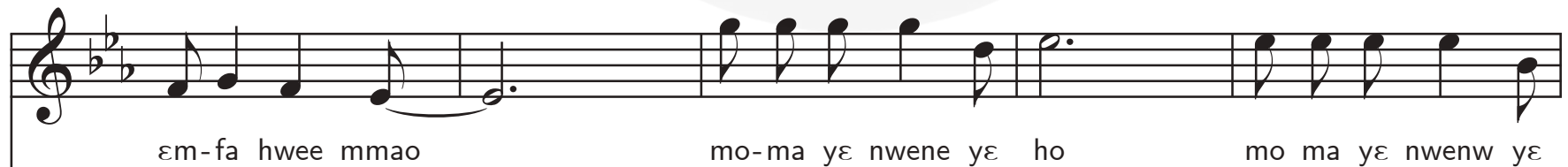

$\mathrm{P}$

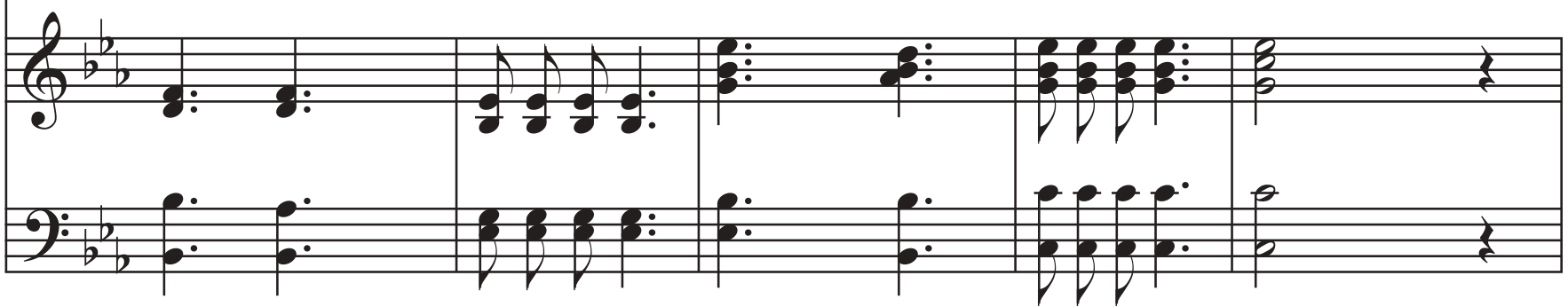



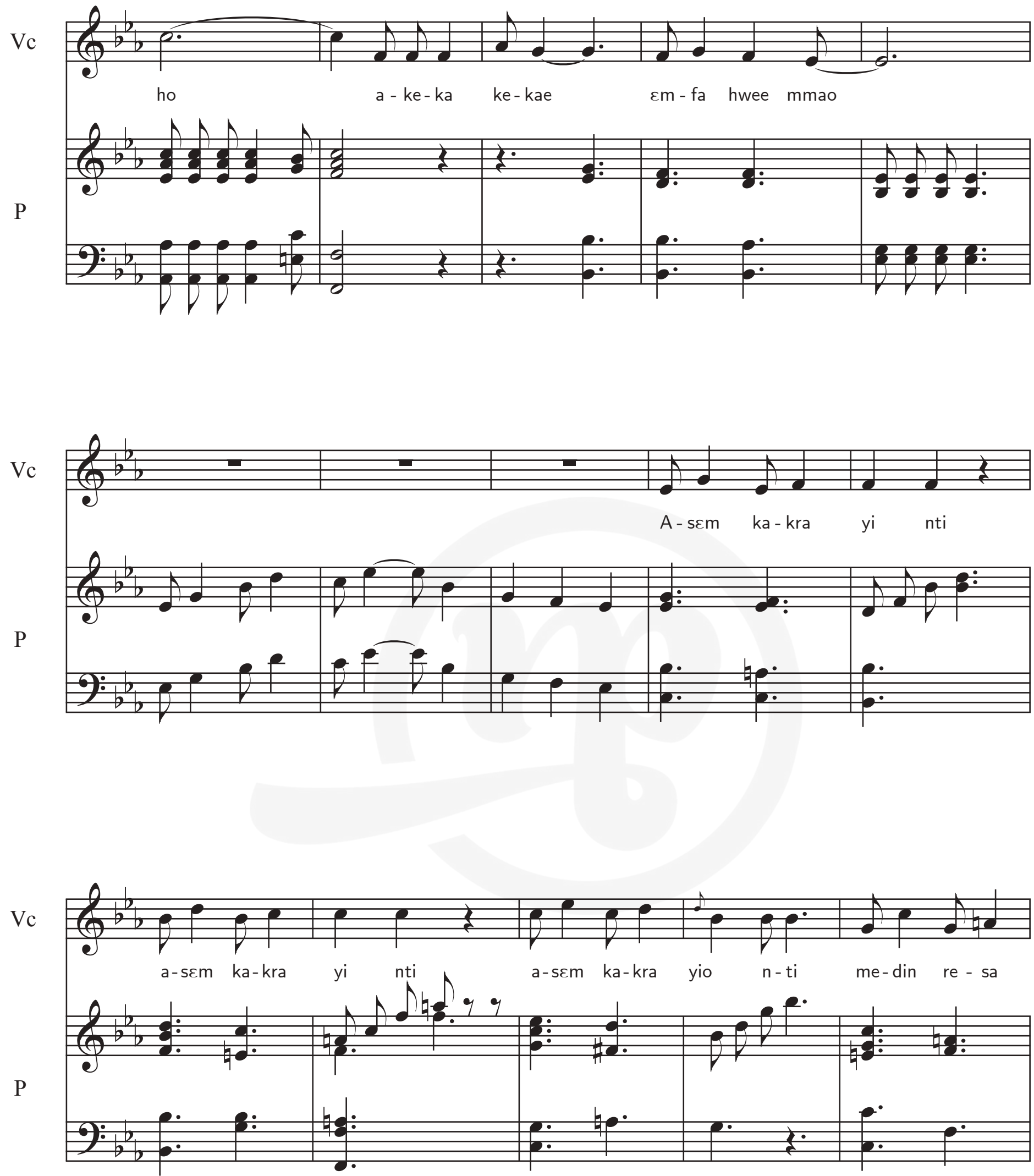
$\mathrm{Vc}$

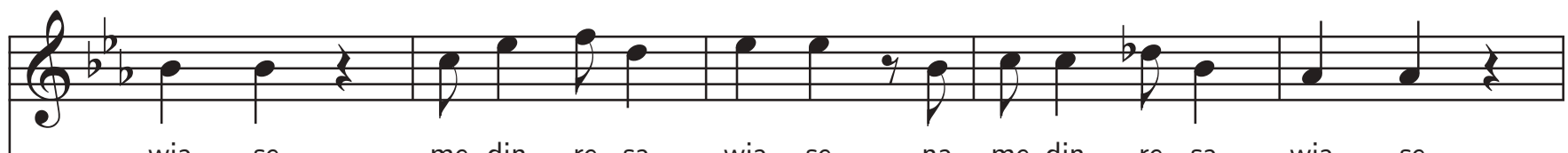

$\mathrm{P}$

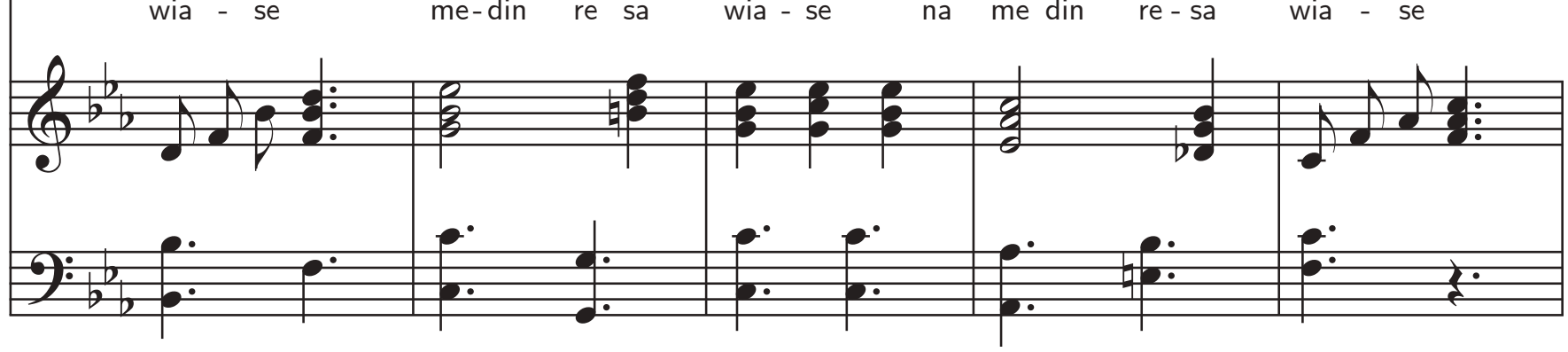

$\mathrm{Vc}$

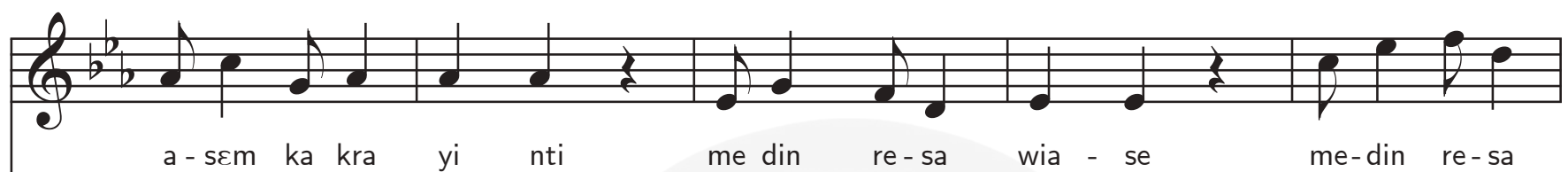

$\mathrm{P}$

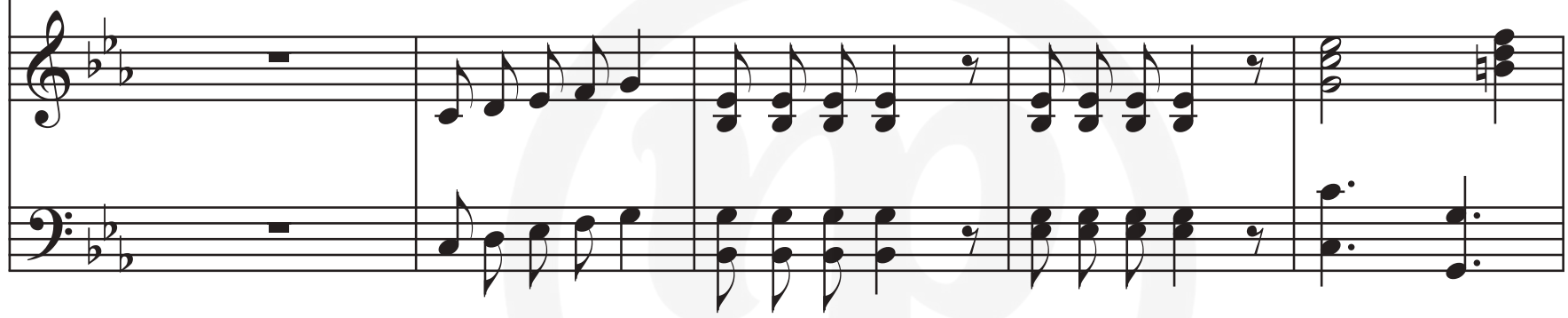

$\mathrm{Vc}$

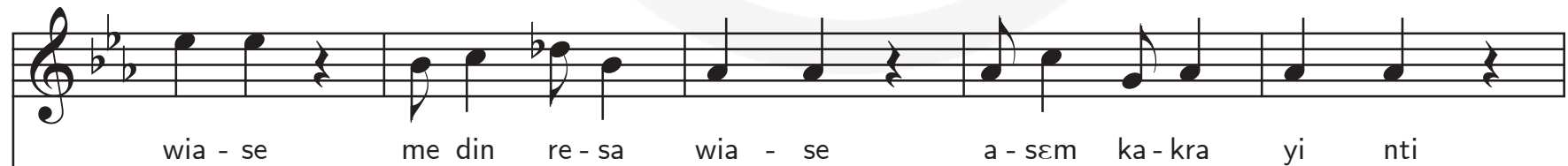

$\mathrm{P}$

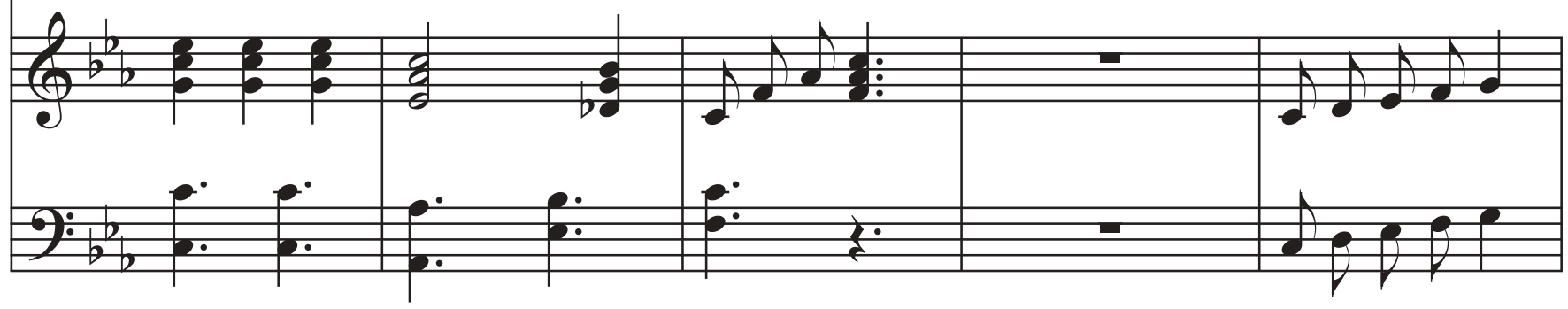


$\mathrm{Vc}$
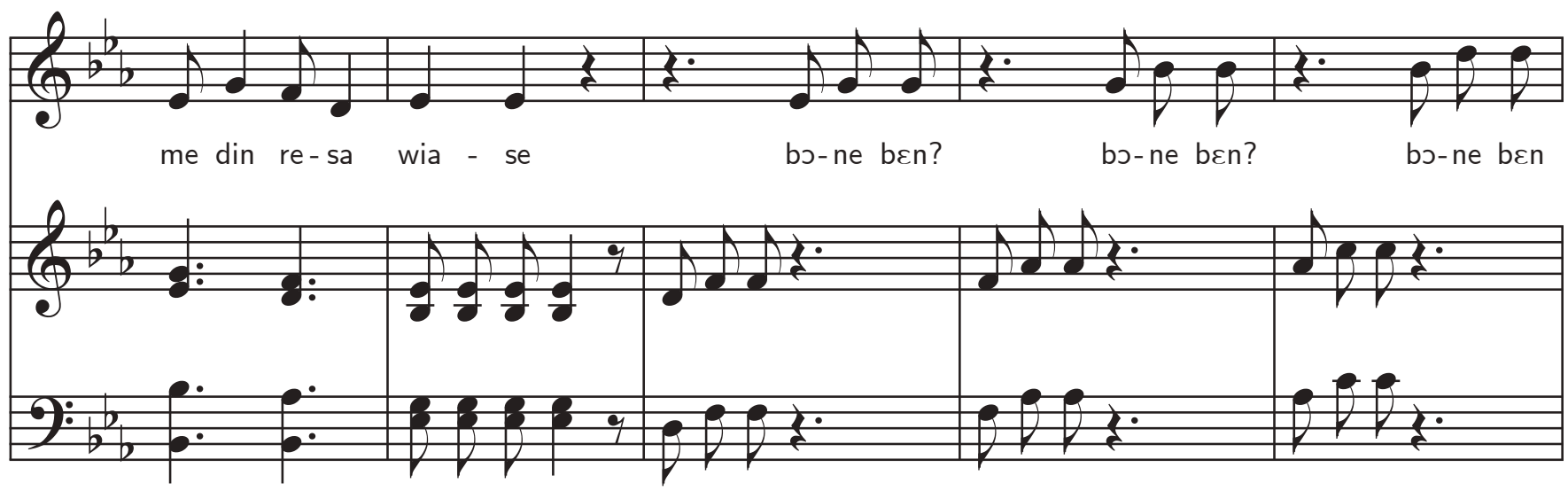

$\mathrm{Vc}$
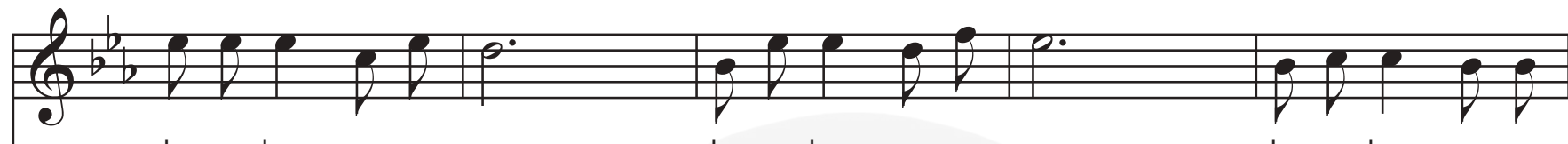

bo-ne ben na ma yeo

bo-ne ben

na ma yeo

bo-ne ben

na ma

$\mathrm{P}$

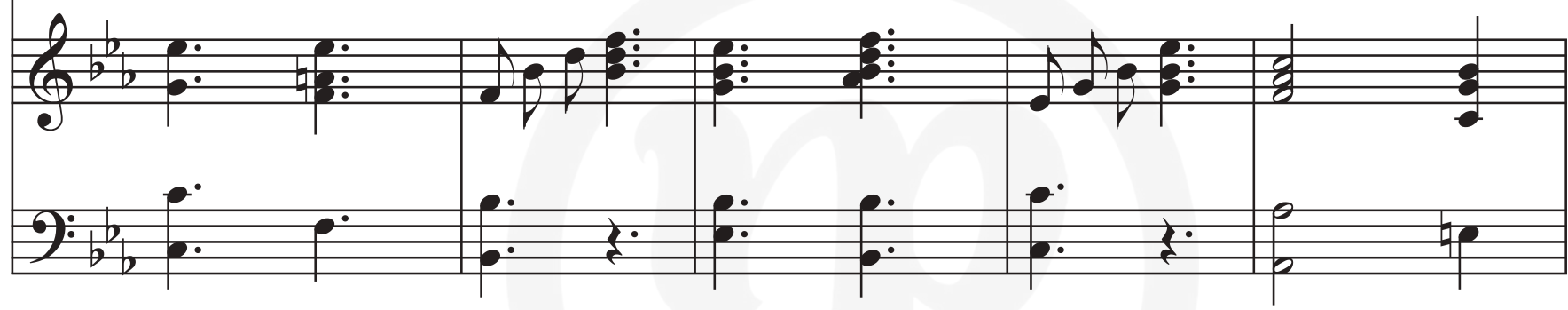

$\mathrm{Vc}$
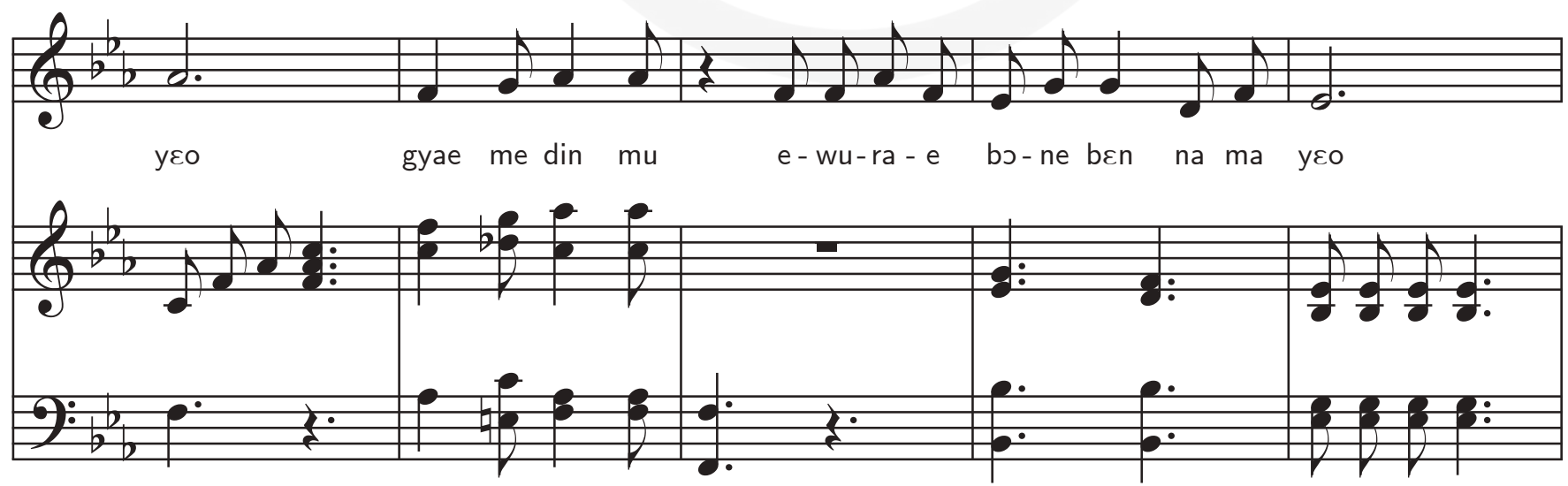

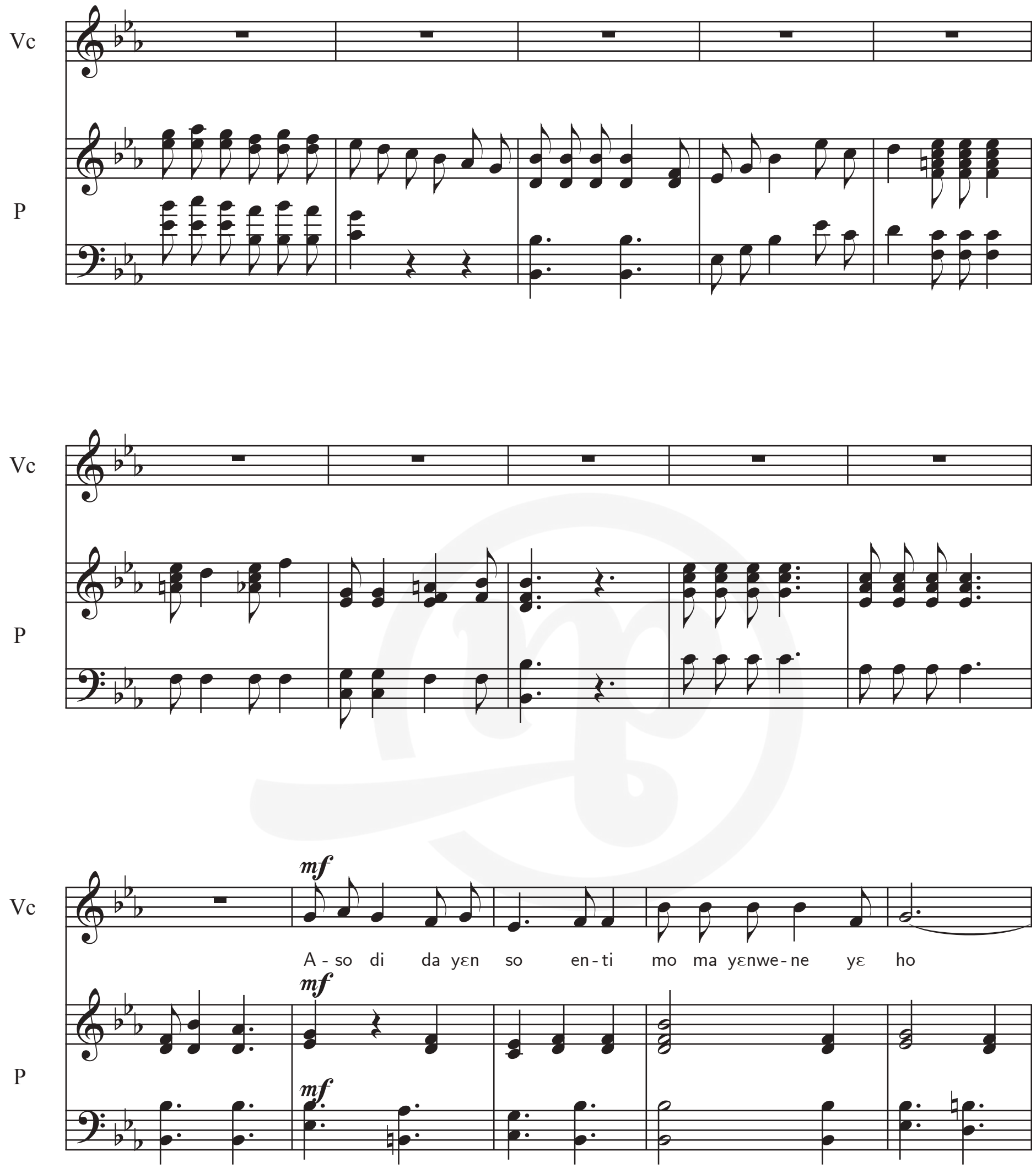
$\mathrm{Vc}$
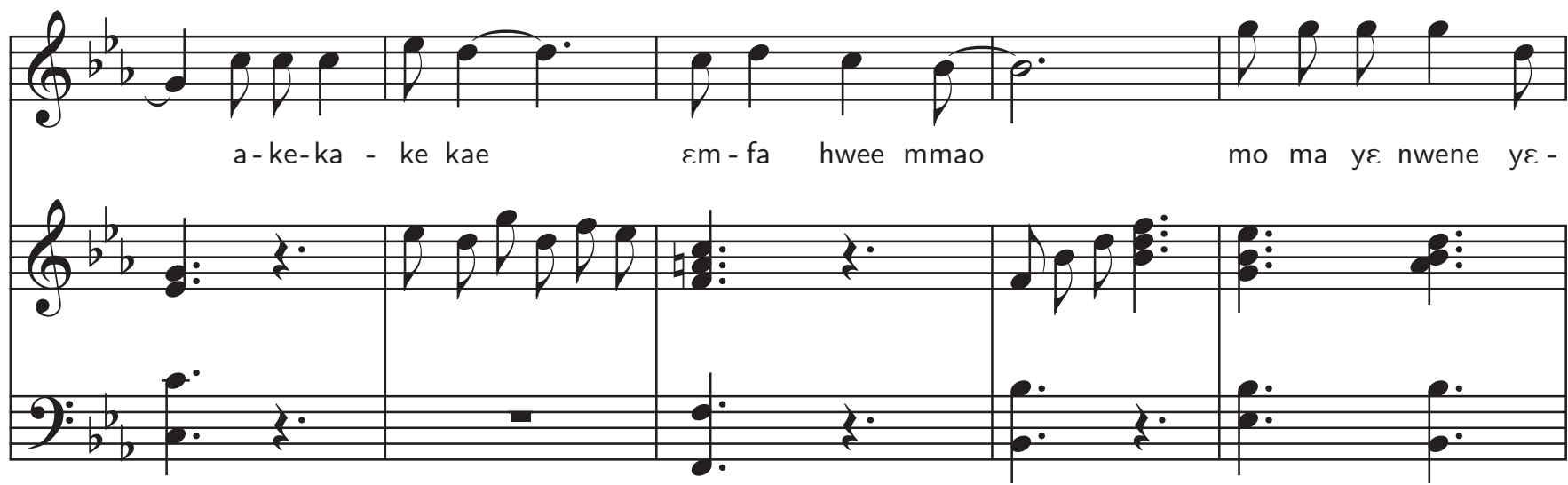

$\mathrm{Vc}$

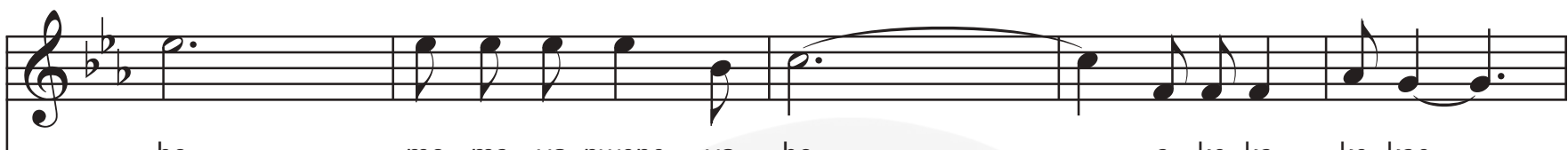

ho

mo ma ye nwene ye ho

a-ke-ka ke kae

$\mathrm{P}$

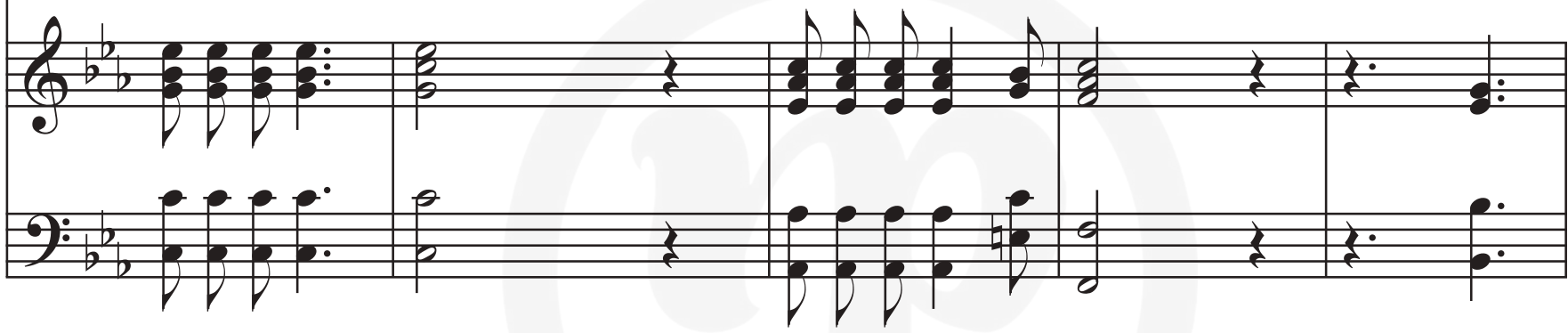

$\mathrm{Vc}$

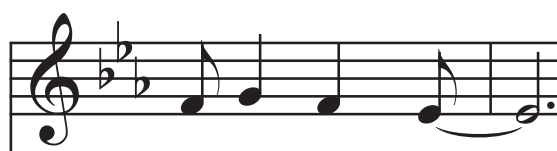

हm-fa hwee mmao

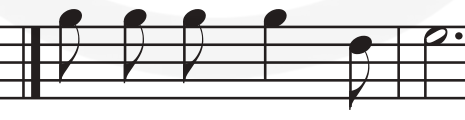

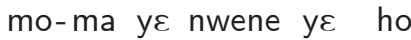

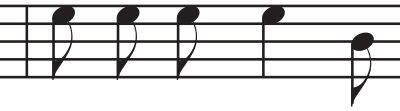

mo ma ye nwenw ye

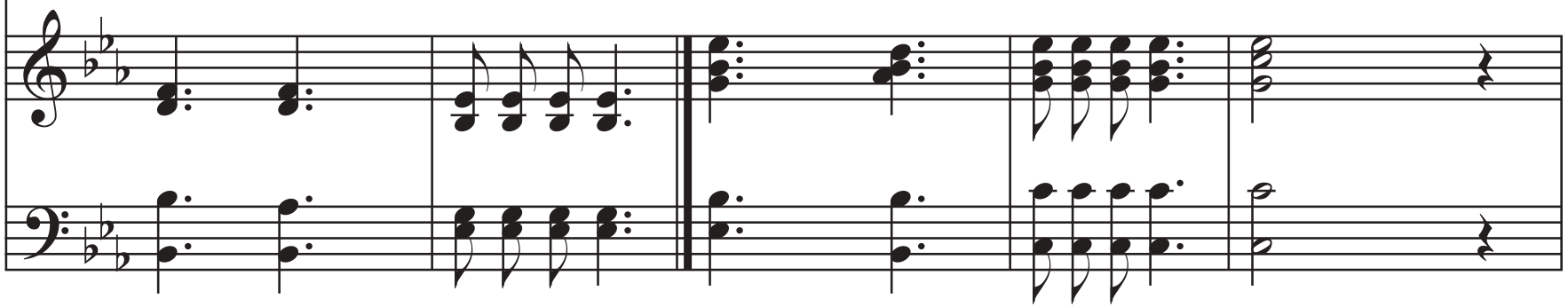



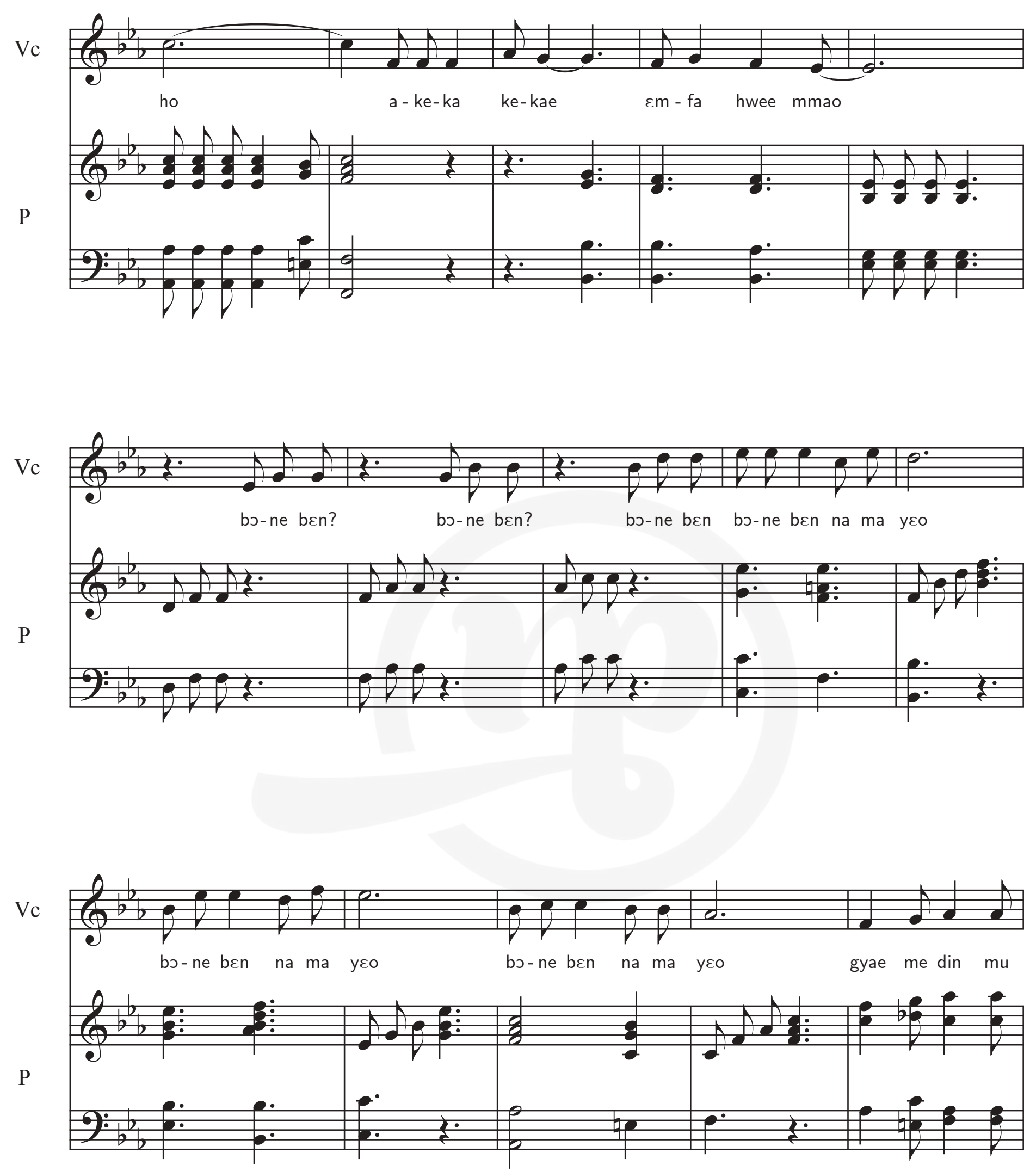
$\mathrm{Vc}$

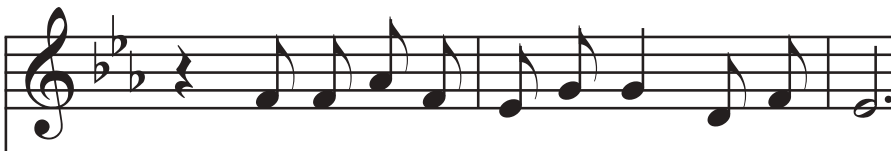

e-wu-ra-e bo-ne ben na ma yeo

$\mathrm{P}$

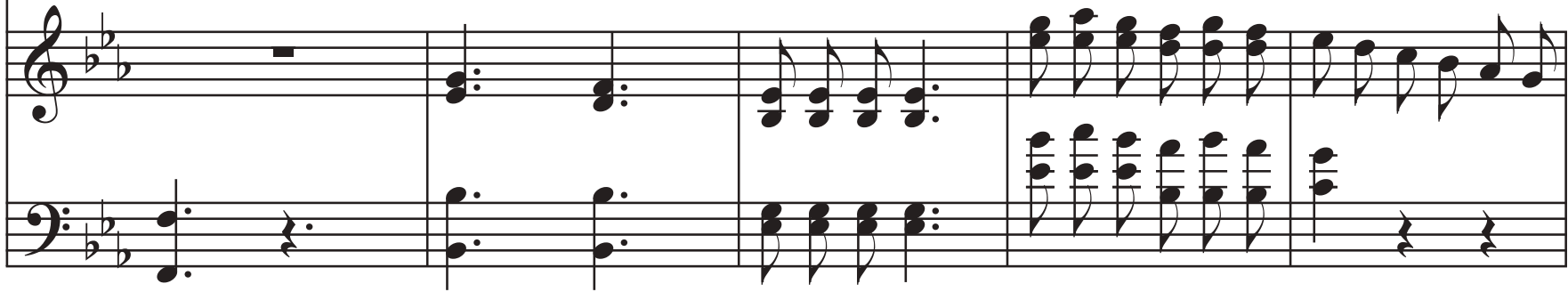

$\mathrm{Vc}$

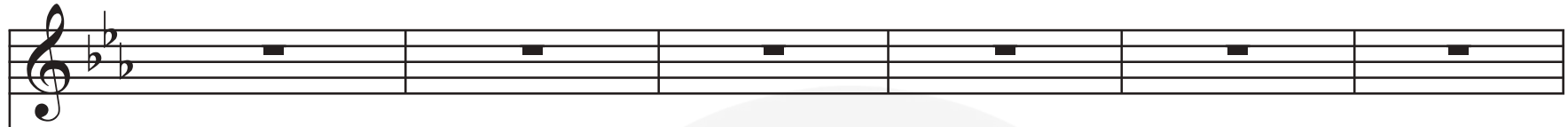

$\mathrm{P}$

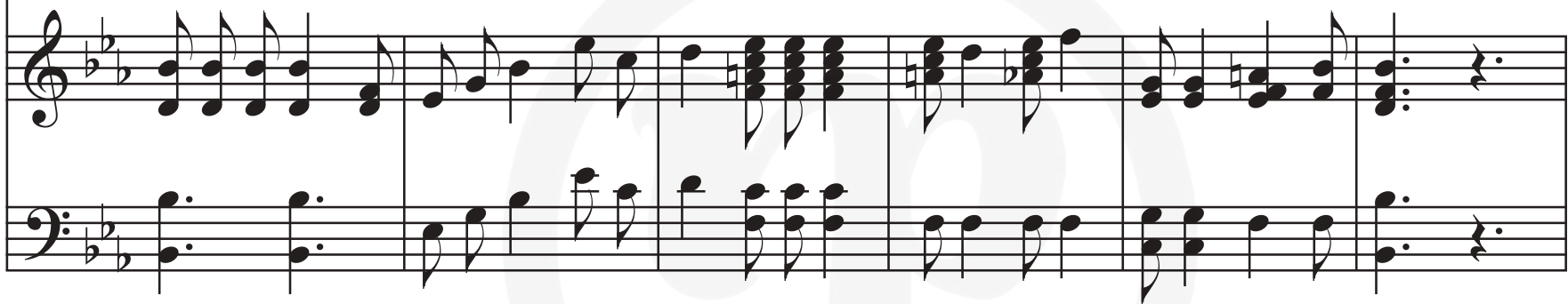

Vc

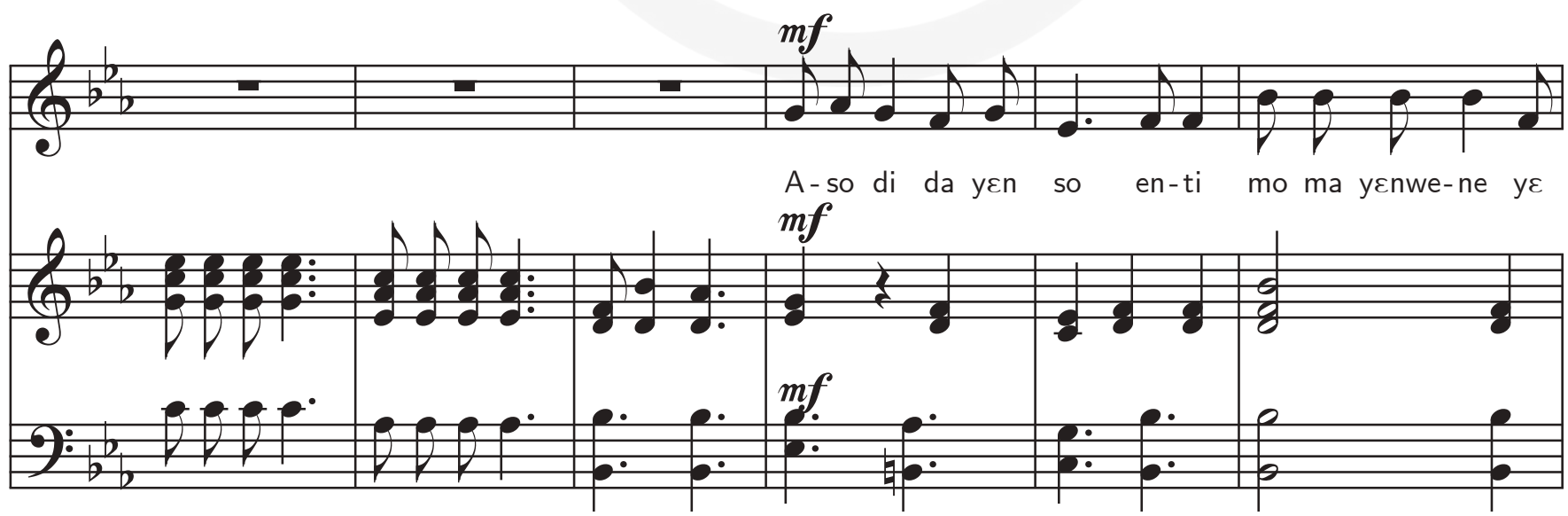


$\mathrm{Vc}$
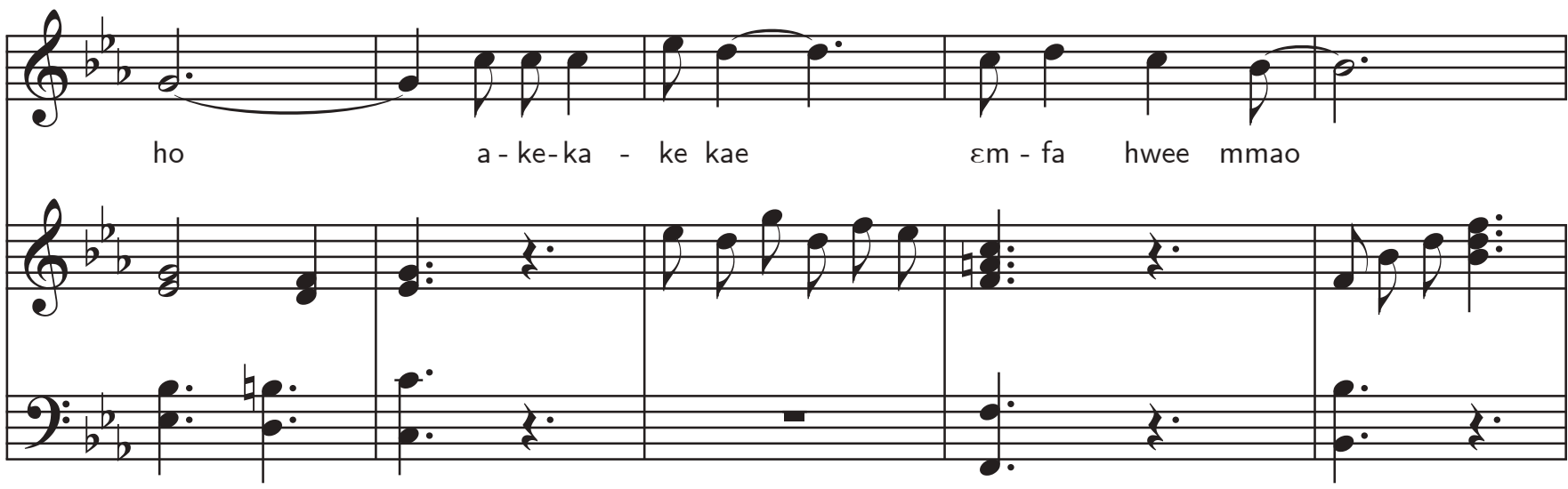

$\mathrm{Vc}$

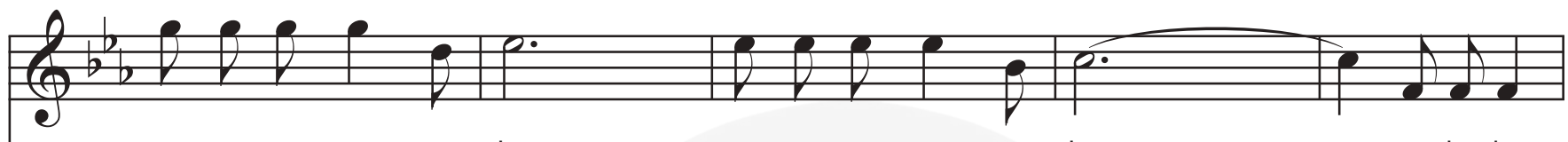
mo ma ye nwene $y \varepsilon-h o$

$\mathrm{P}$

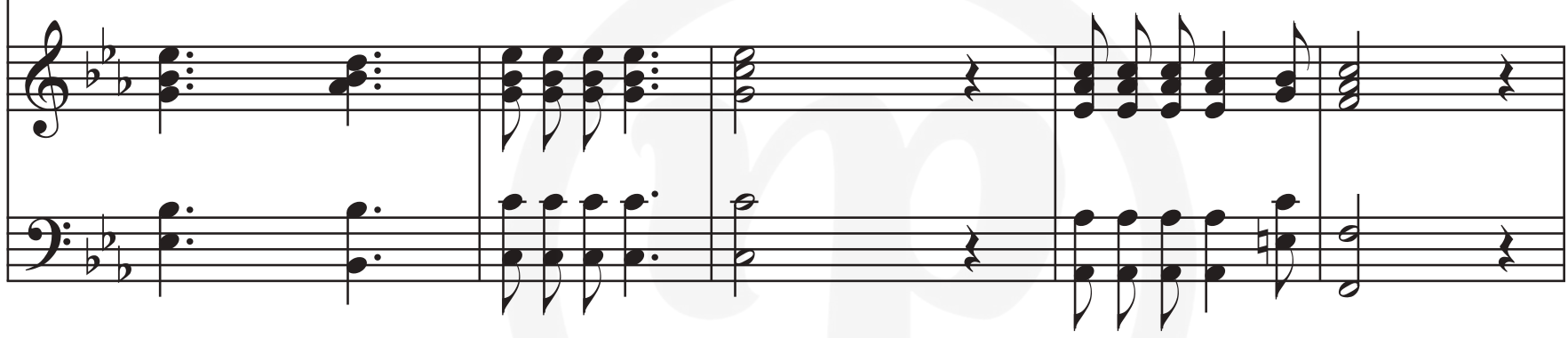

$\mathrm{Vc}$



ke kae $\quad \varepsilon m-f a \quad$ hwee mmao
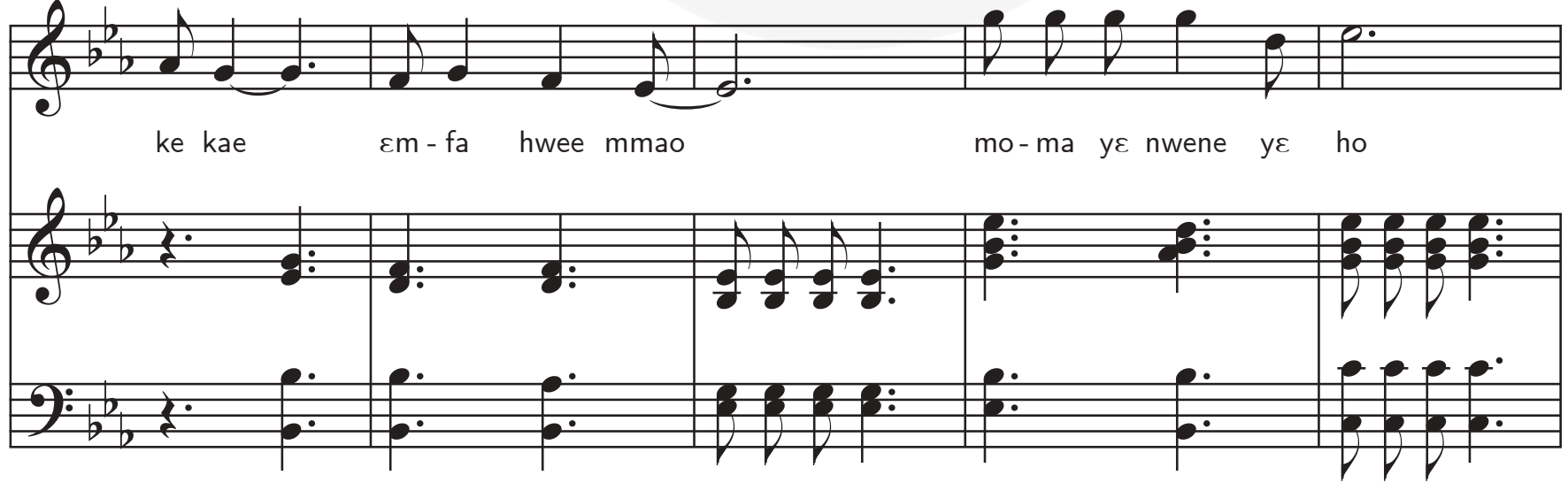
$\mathrm{Vc}$

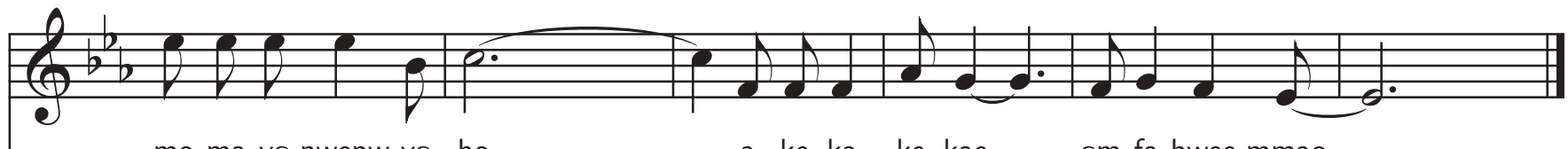

mo ma ye nwenw ye ho

a-ke-ka ke-kae

$\varepsilon \mathrm{m}$-fa hwee mmao

$\mathrm{P}$

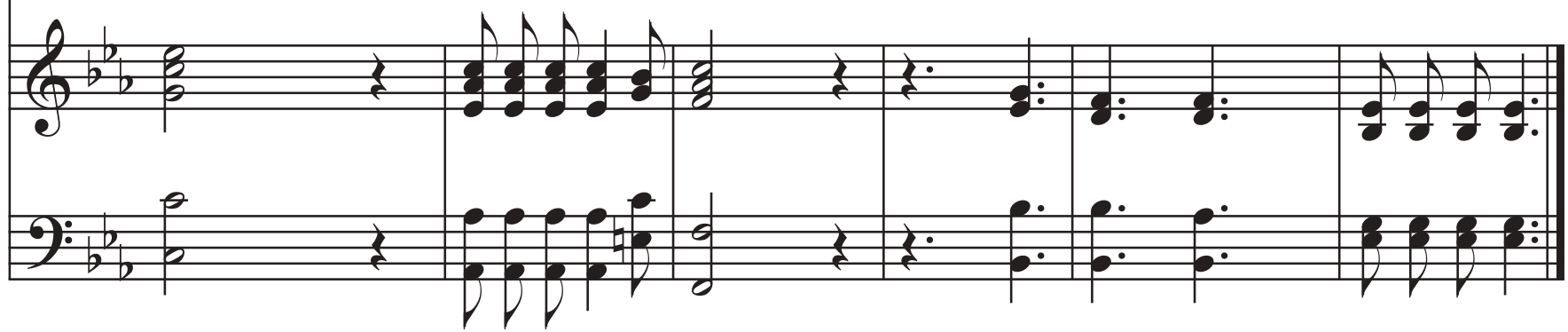




\section{JBวB ADZE \\ (It will come to an end)}

Moderato

Joshua Alfred Amuah
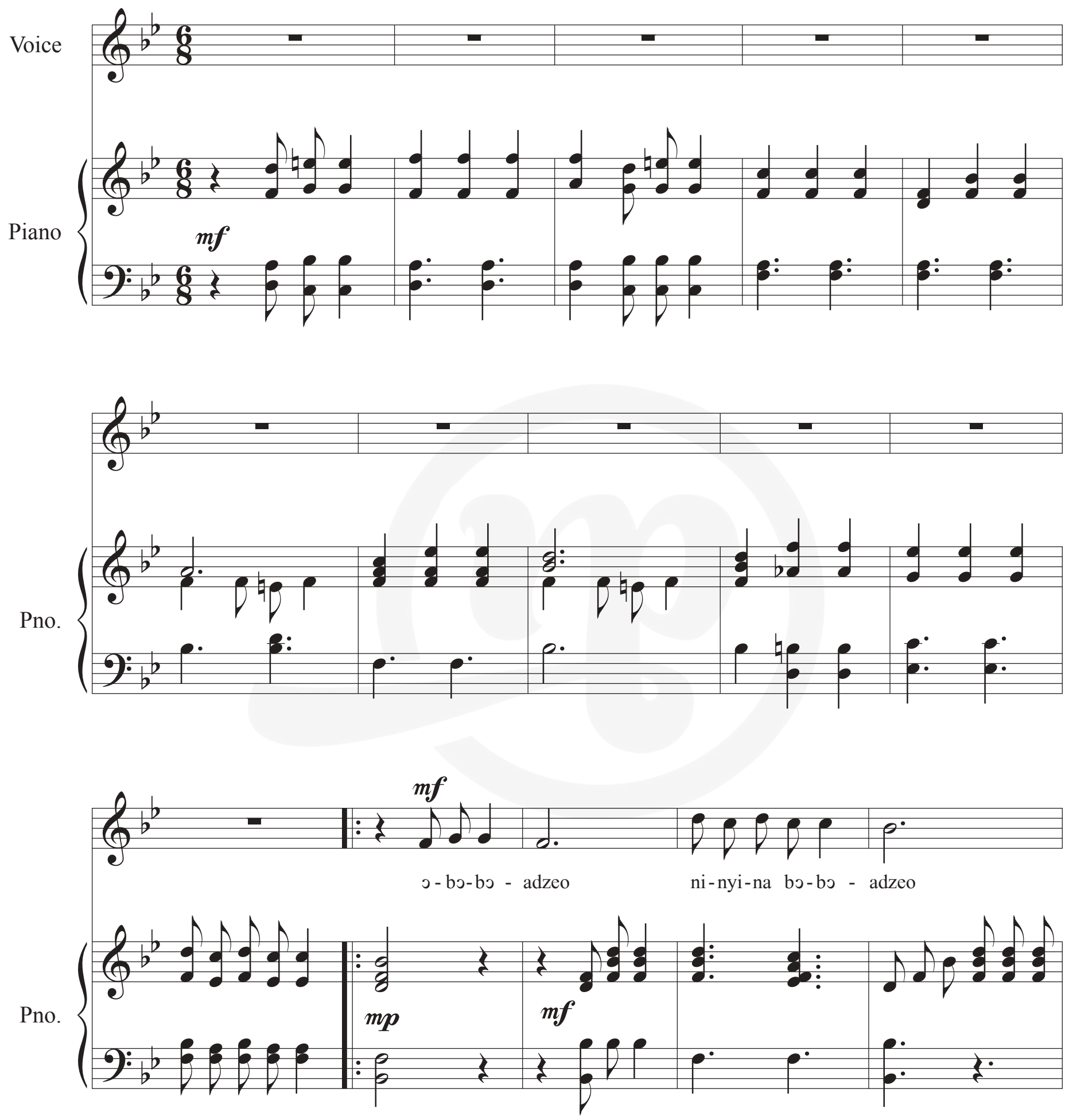

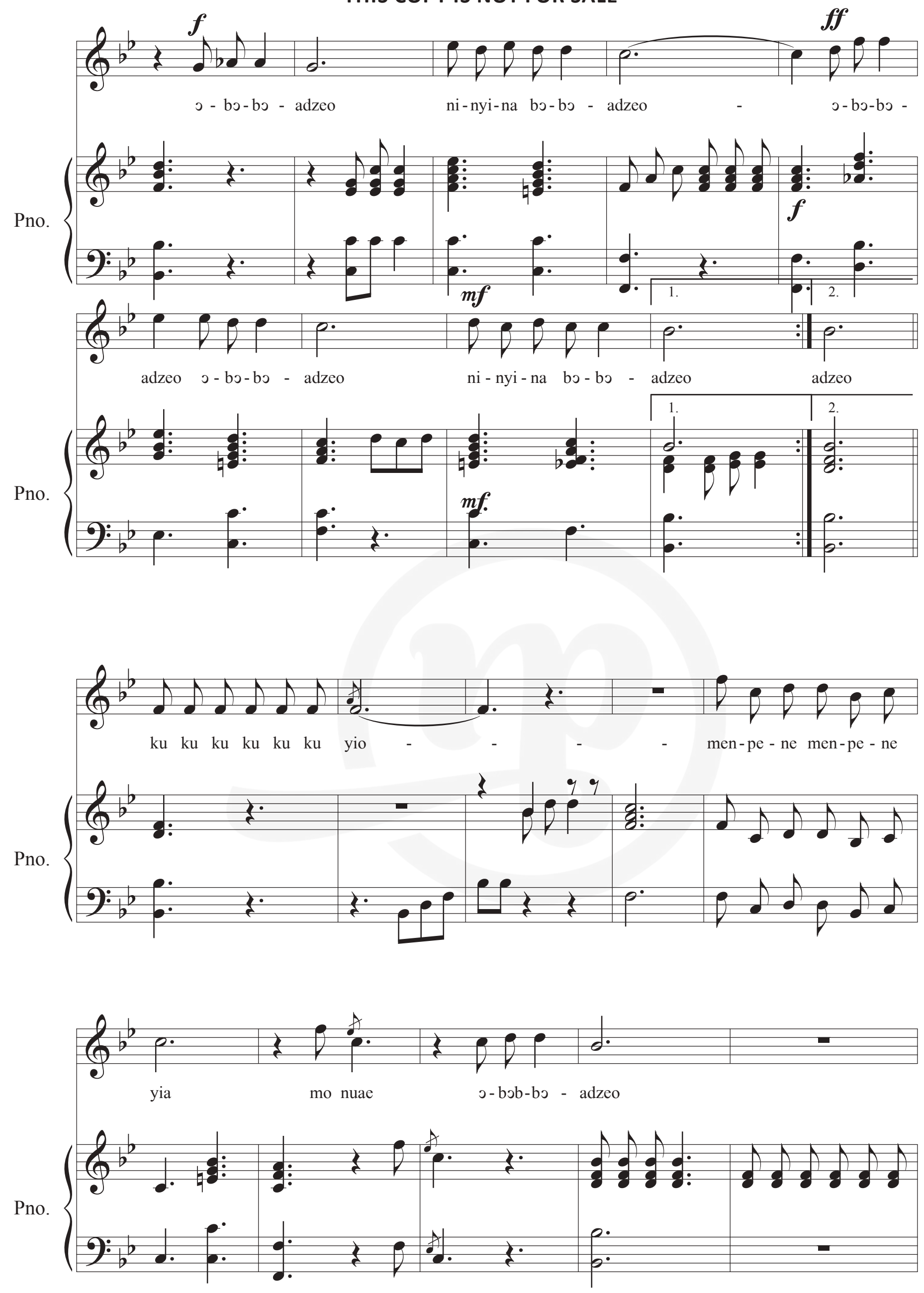

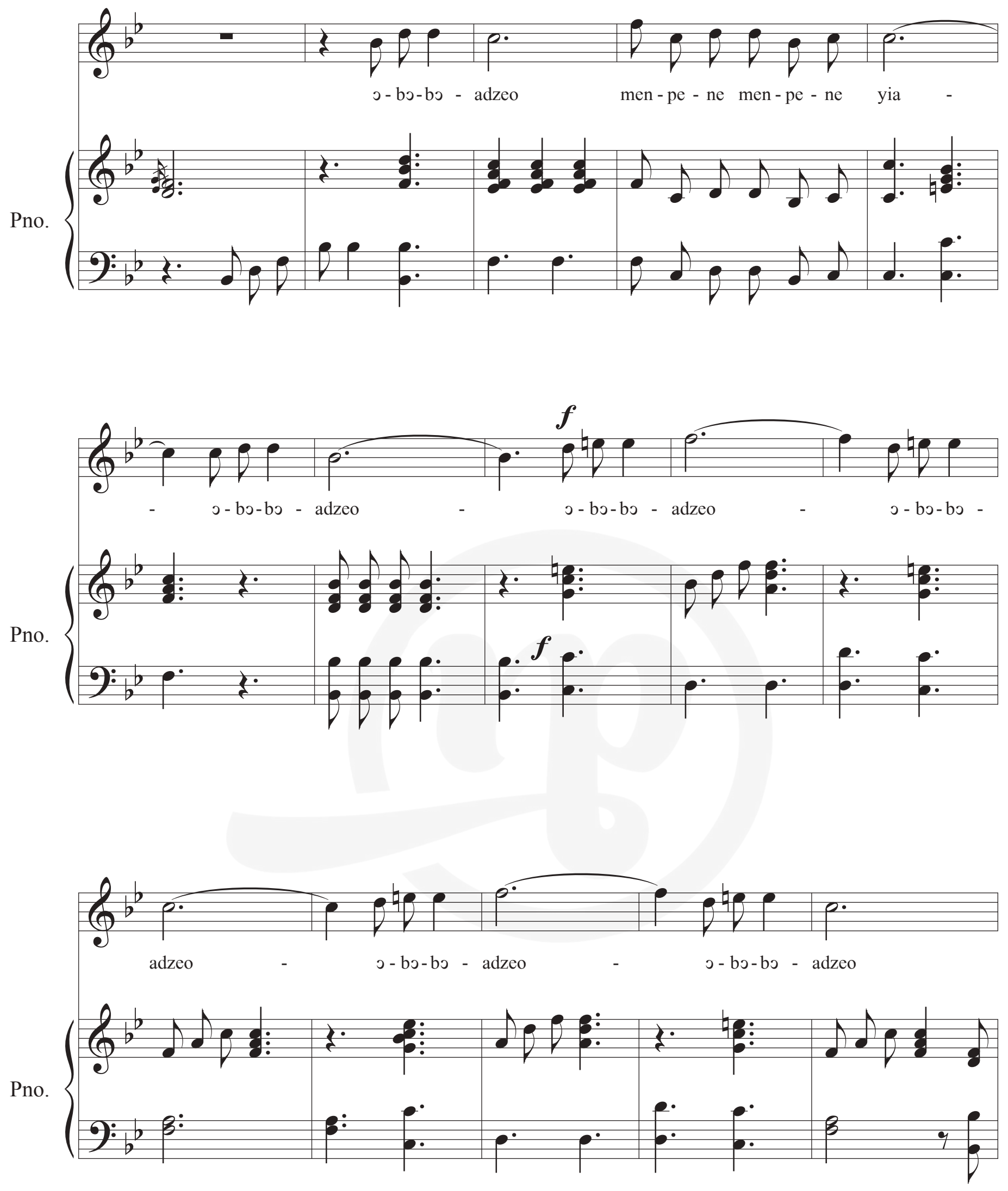

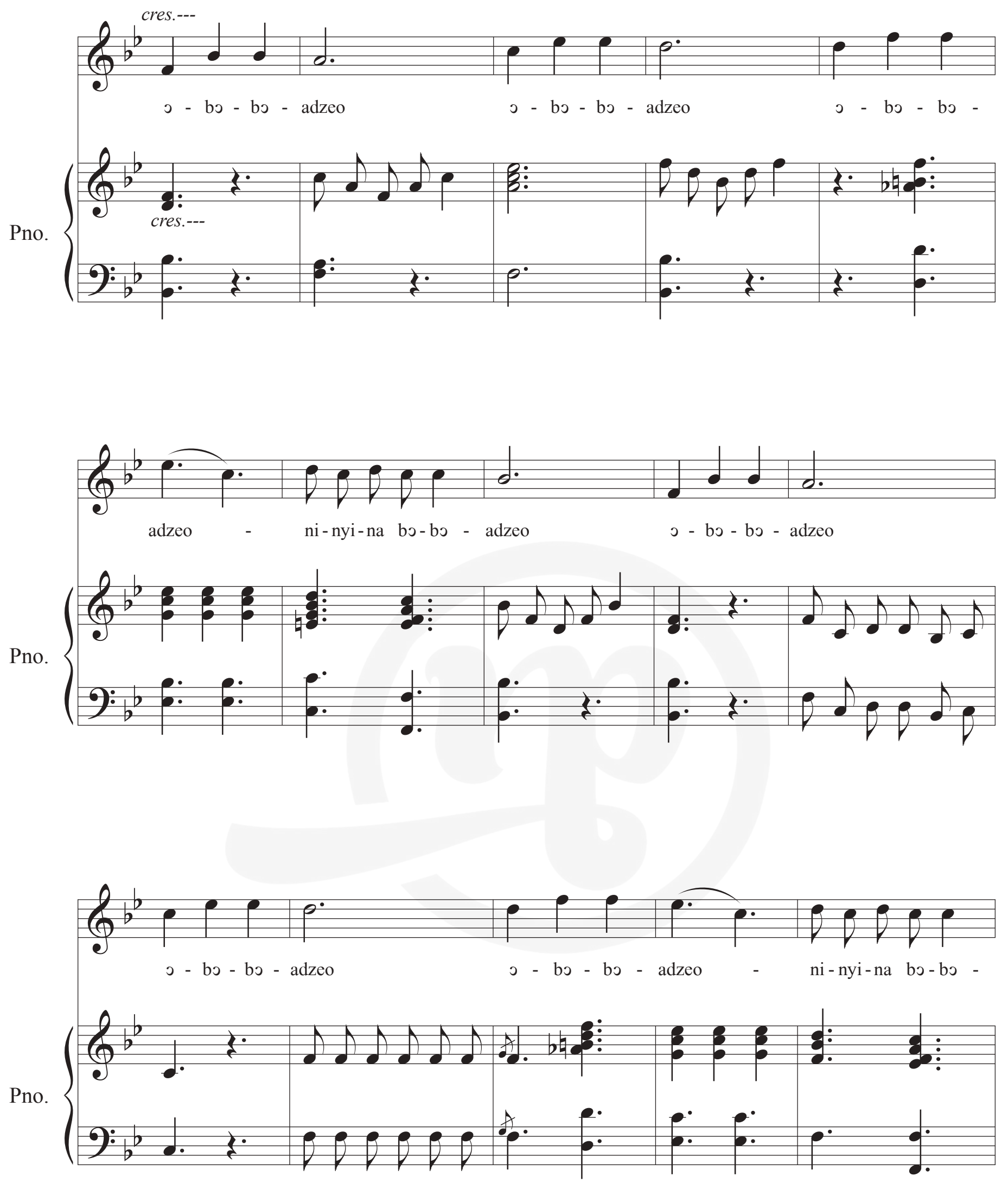

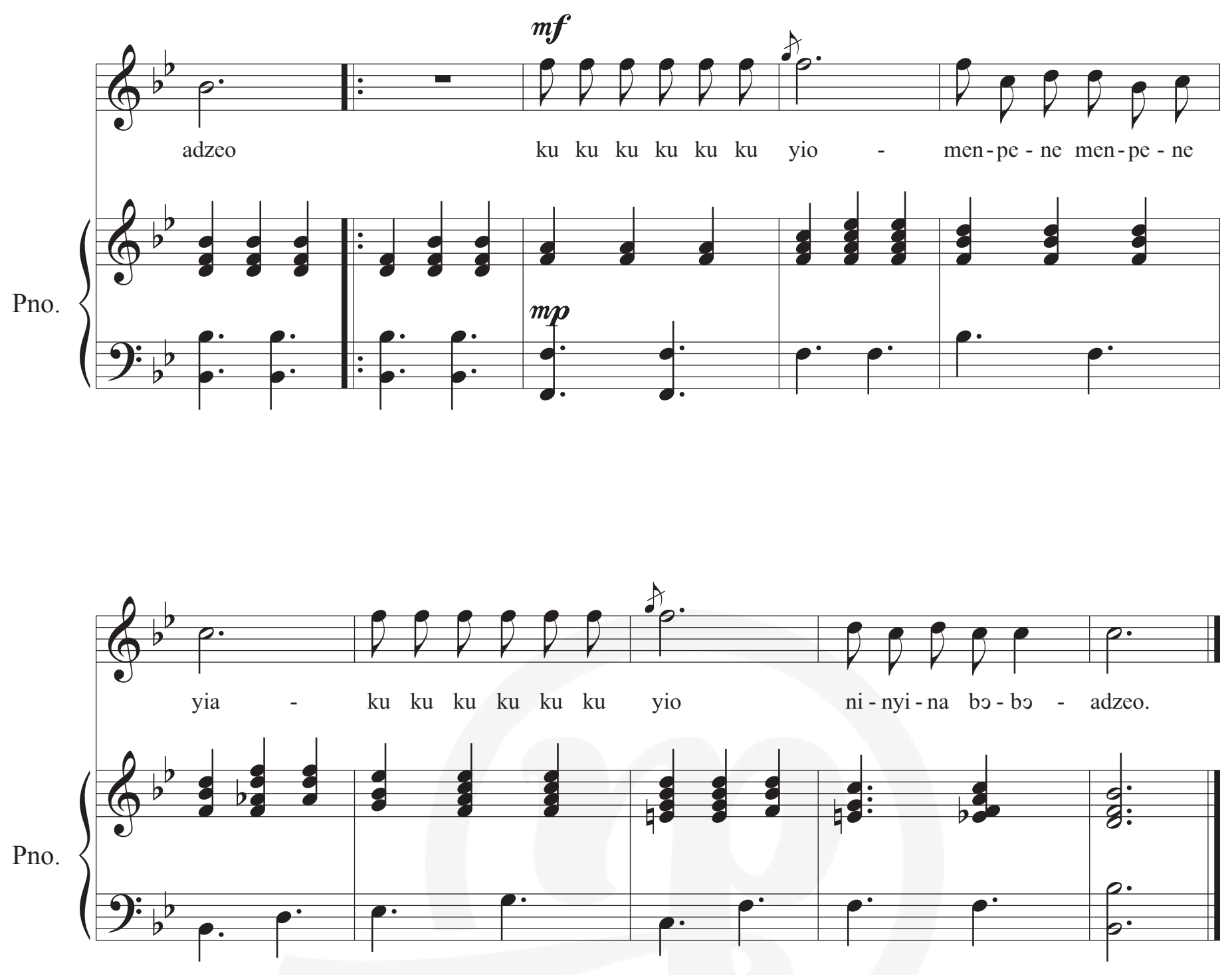


\section{BOM NANTSEW (Lead me On)}

Adapted from I.D. Riverson's Bom Nantsew SATB

Arrangement for Atenteben/Trumpet and Piano

Joshua A. Amuah 14th May 2019
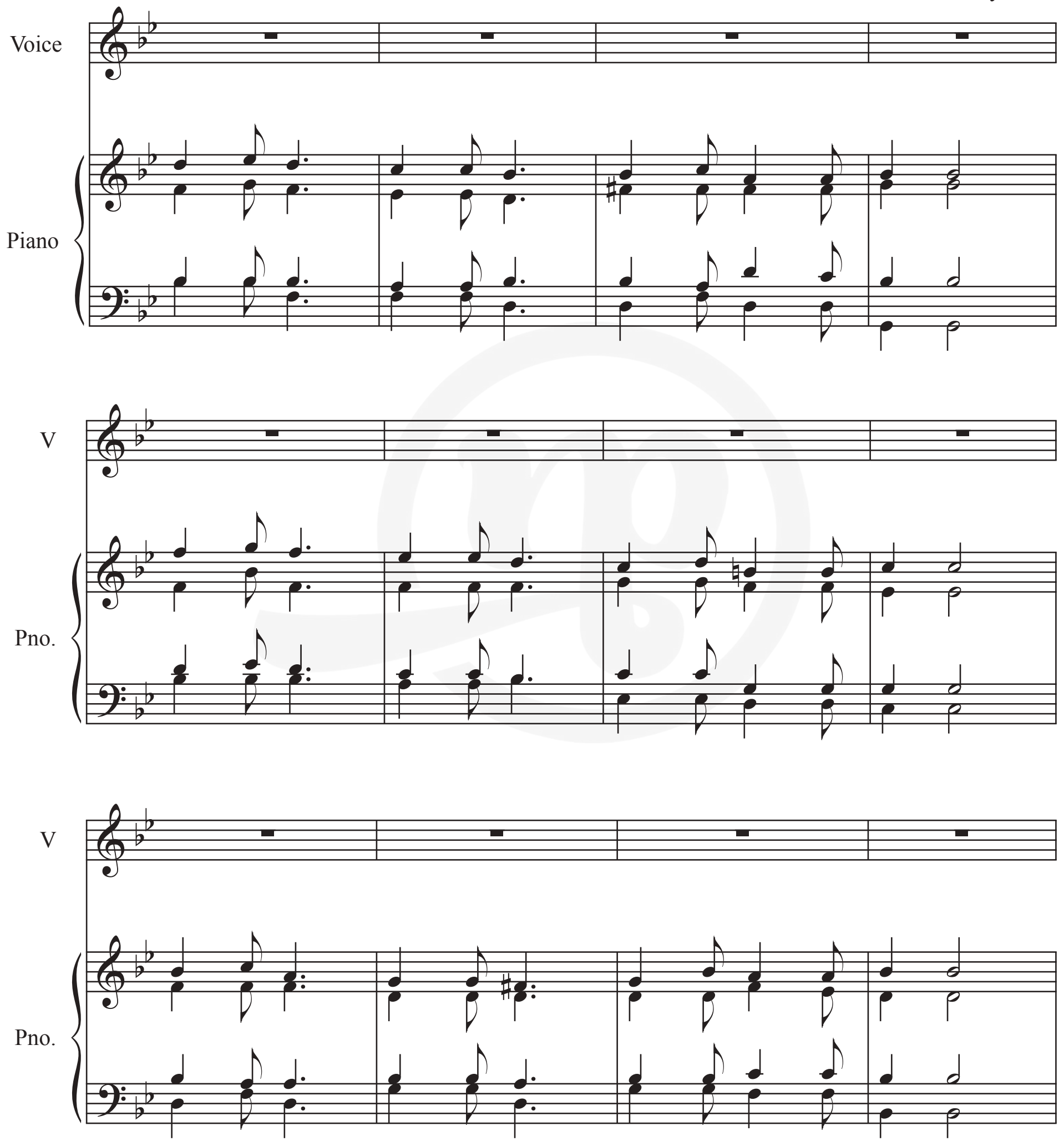

Voice Solo with Piano and Choruses for T.T.B.B | 20 

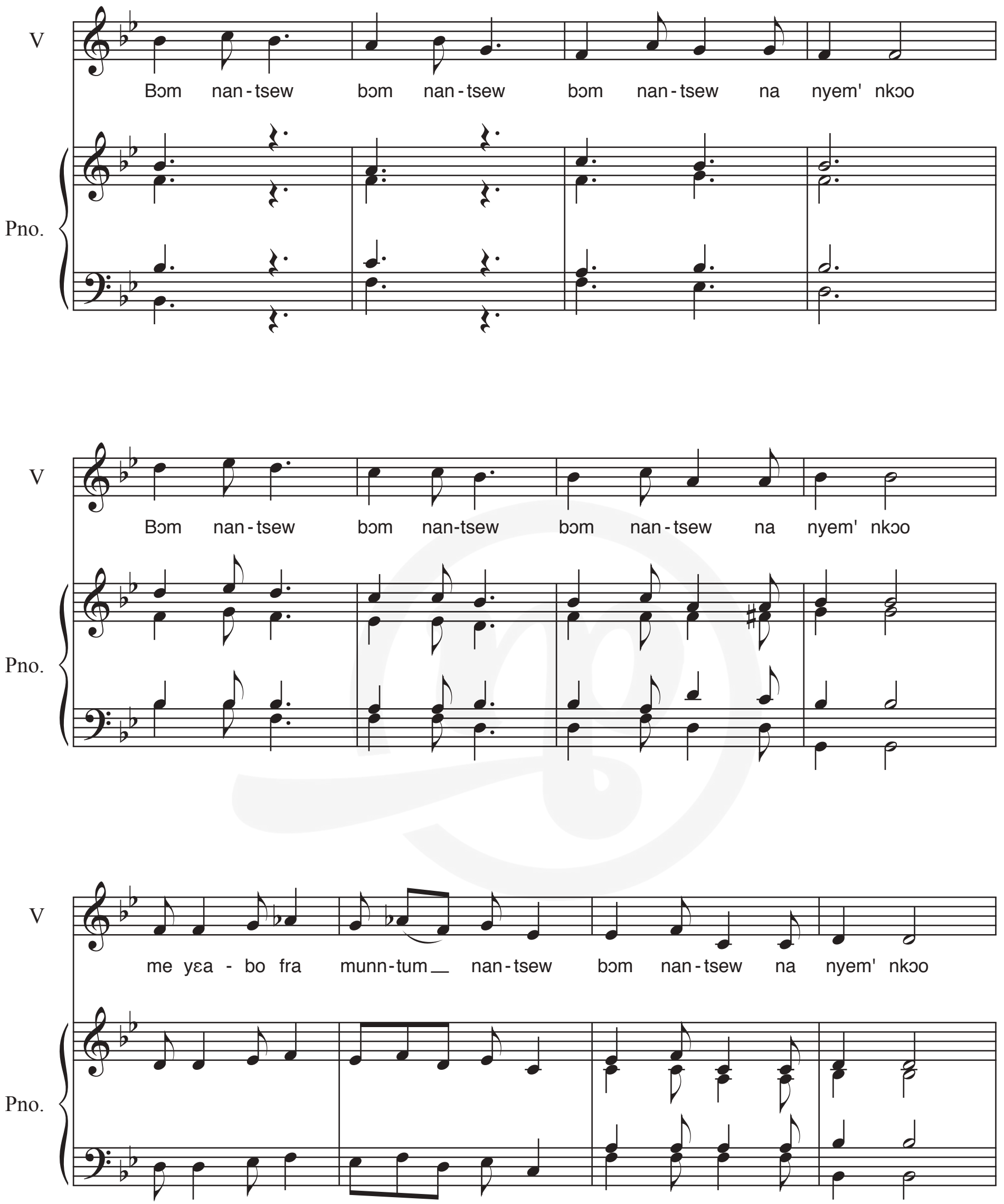

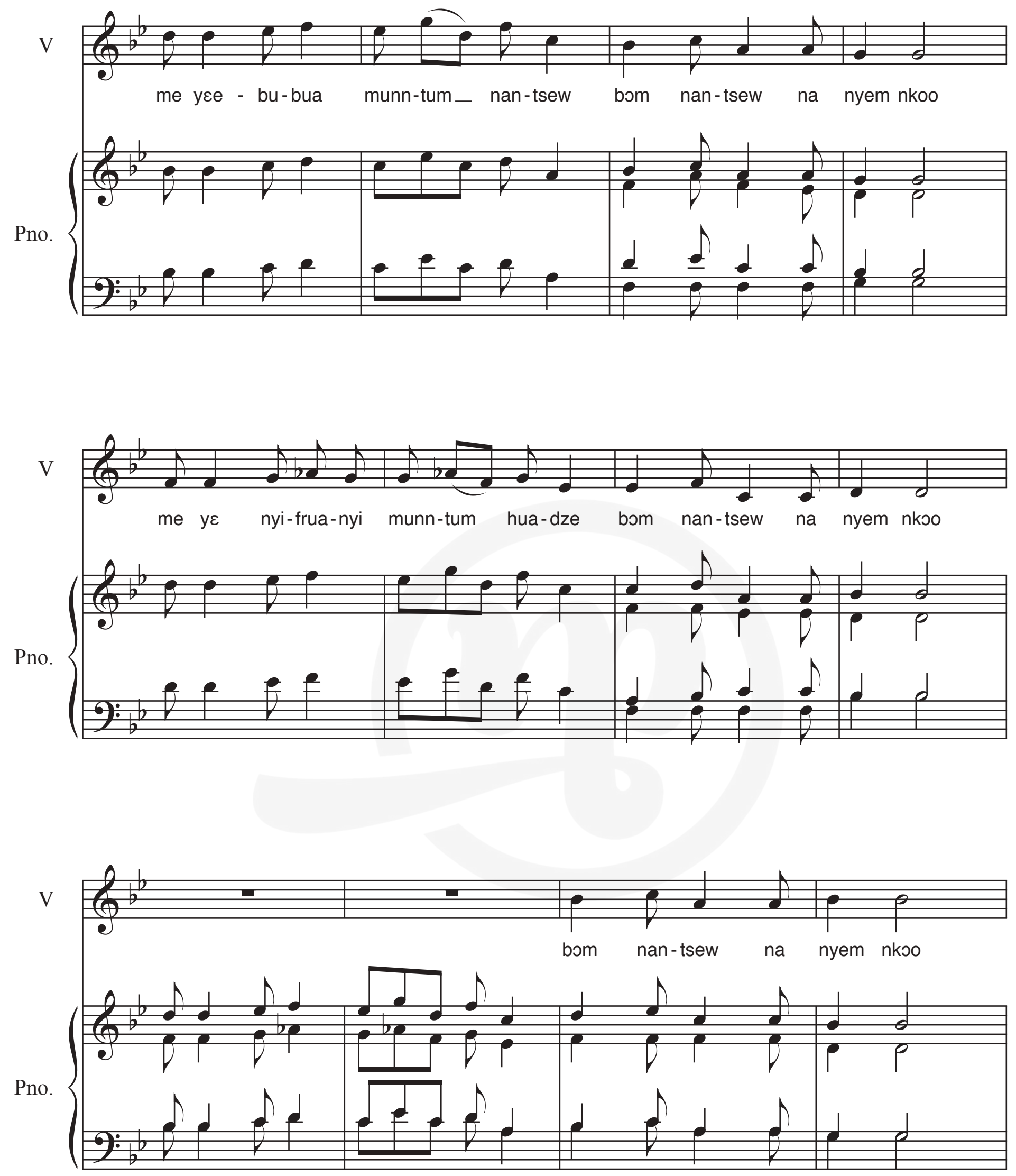

Voice Solo with Piano and Choruses for T.T.B.B | 22 


\section{$\mathrm{V}$}

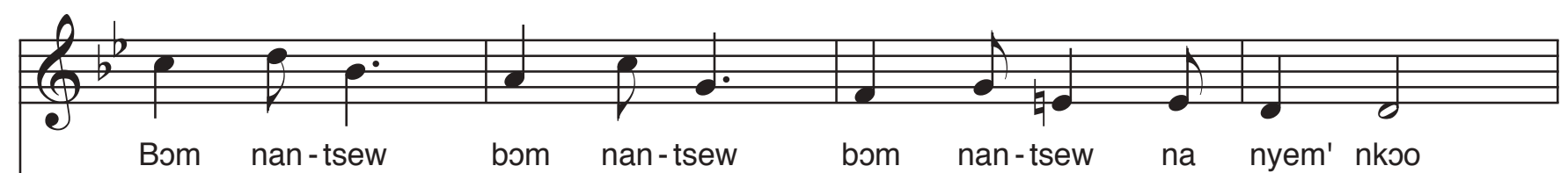

Pno.

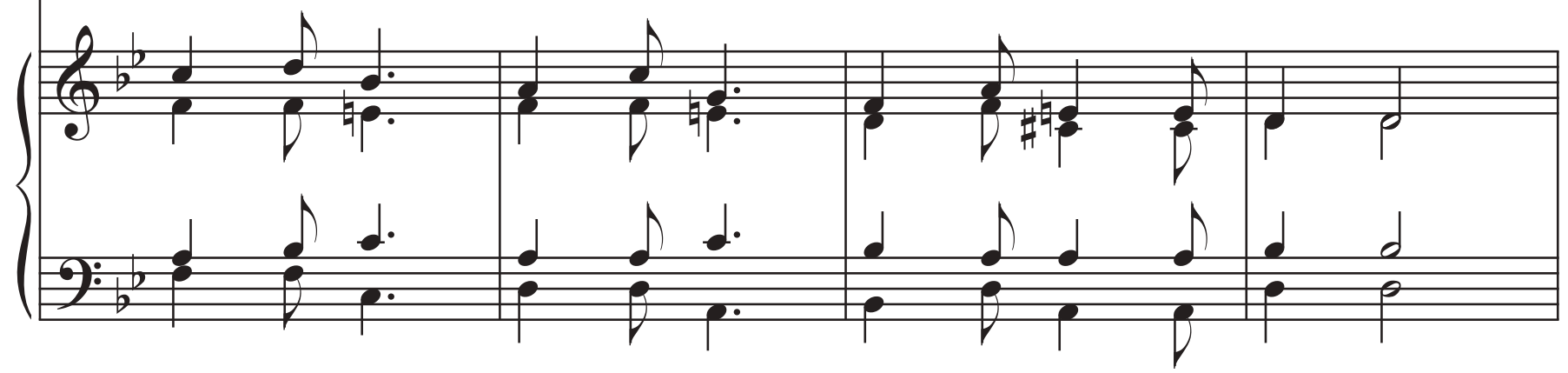

Pno.
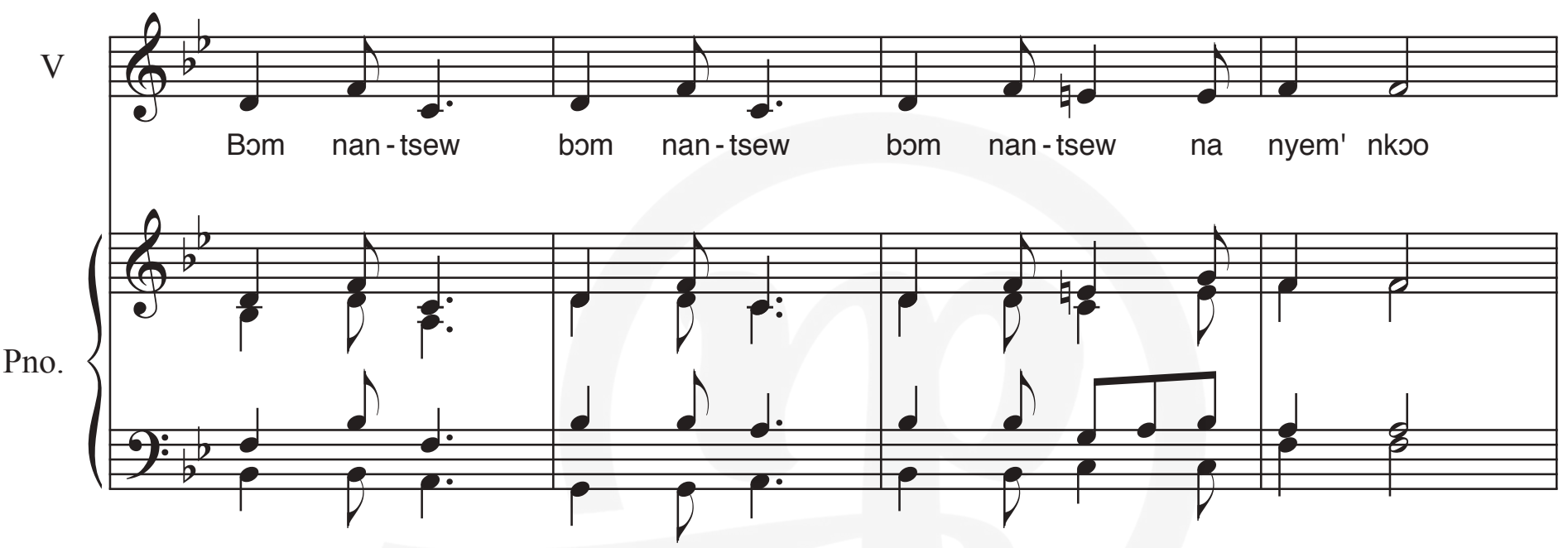

V

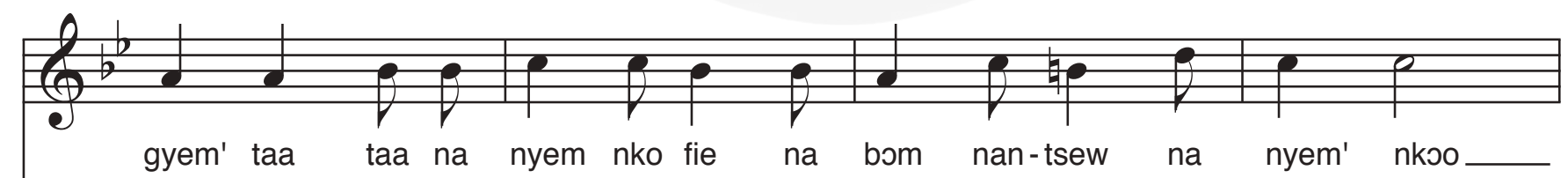

Pno.

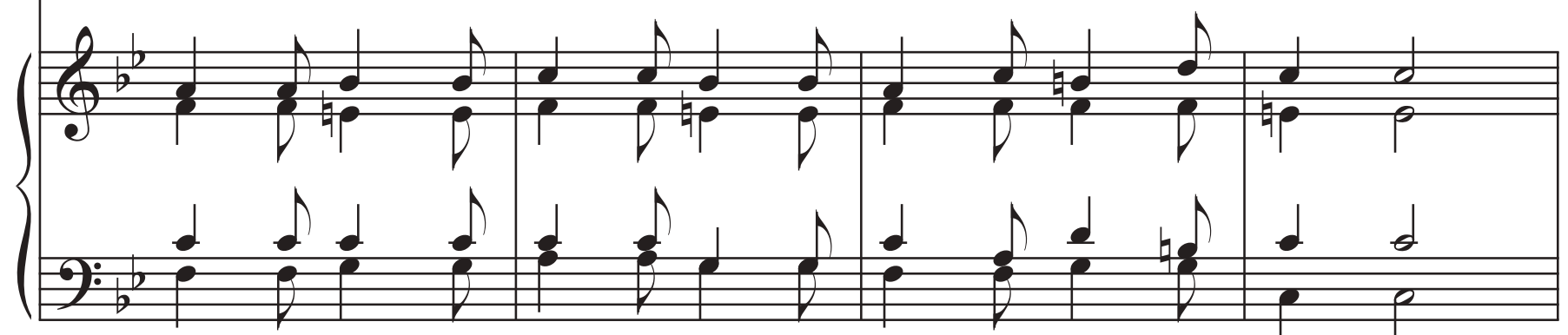



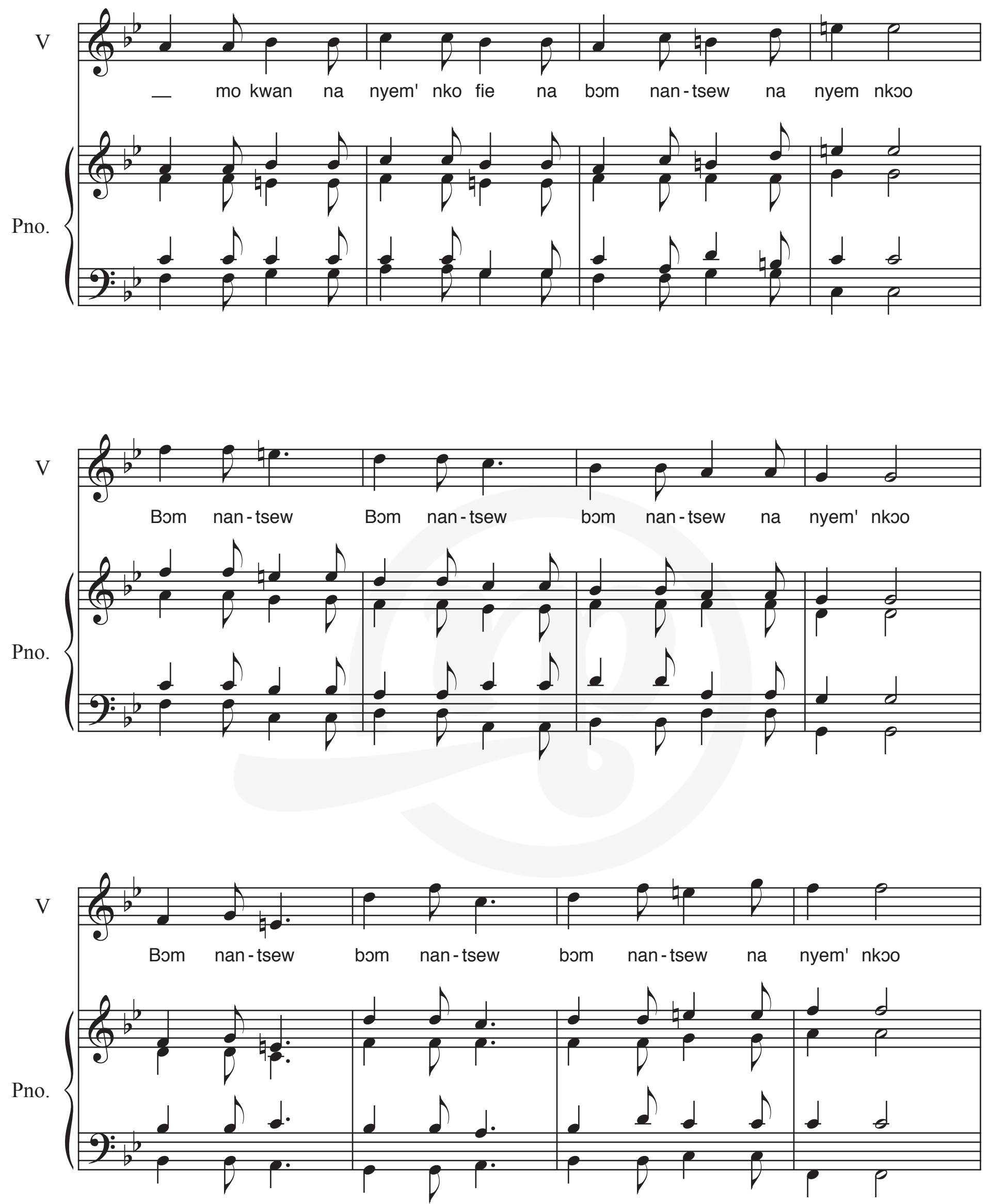

Voice Solo with Piano and Choruses for T.T.B.B | 24 

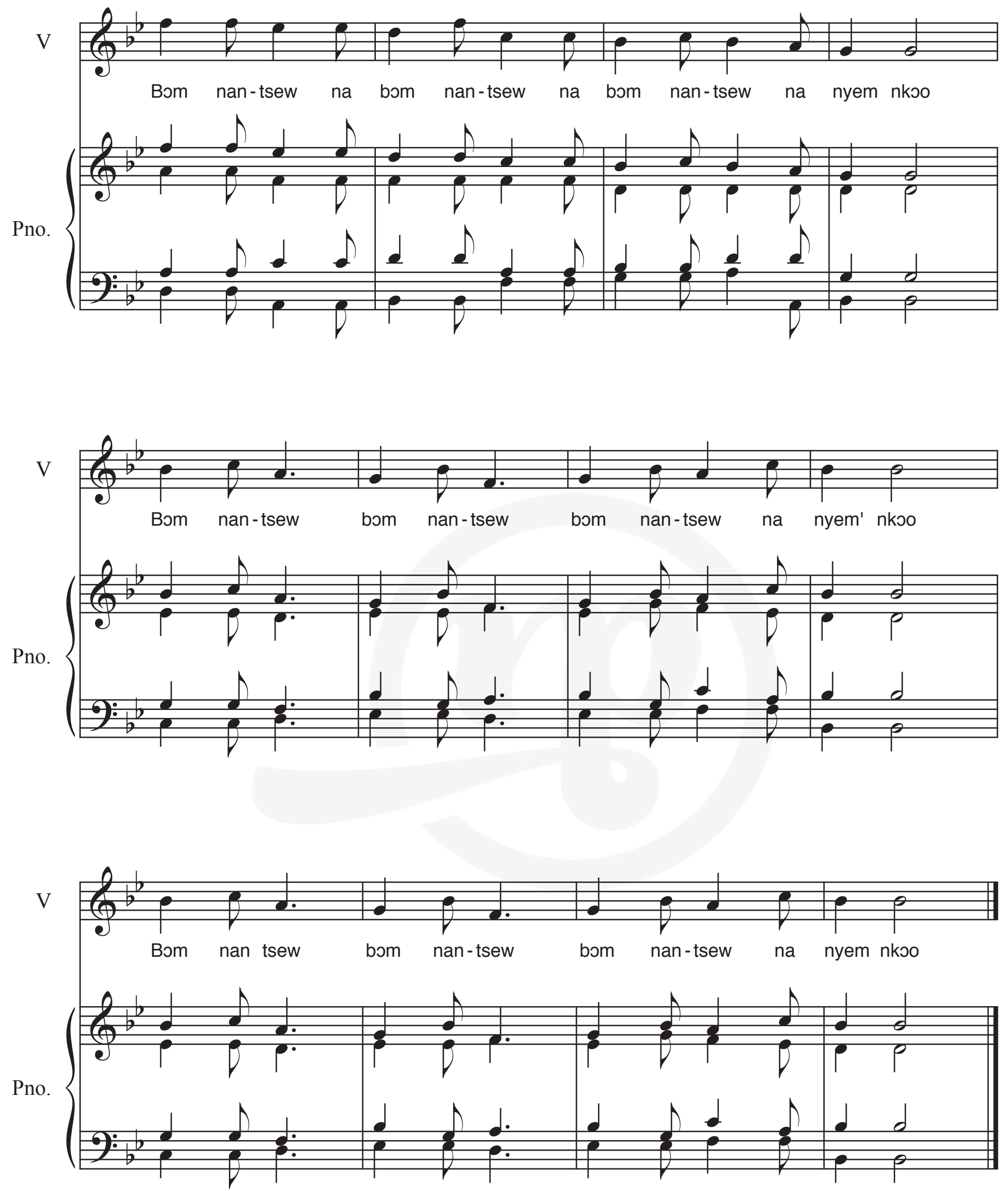

Voice Solo with Piano and Choruses for T.T.B.B | 25 
THIS COPY IS NOT FOR SALE

\section{NKOTWA DU \\ (You Won't ScoreTen)}

Joshua A. Amuah

10th May 2019
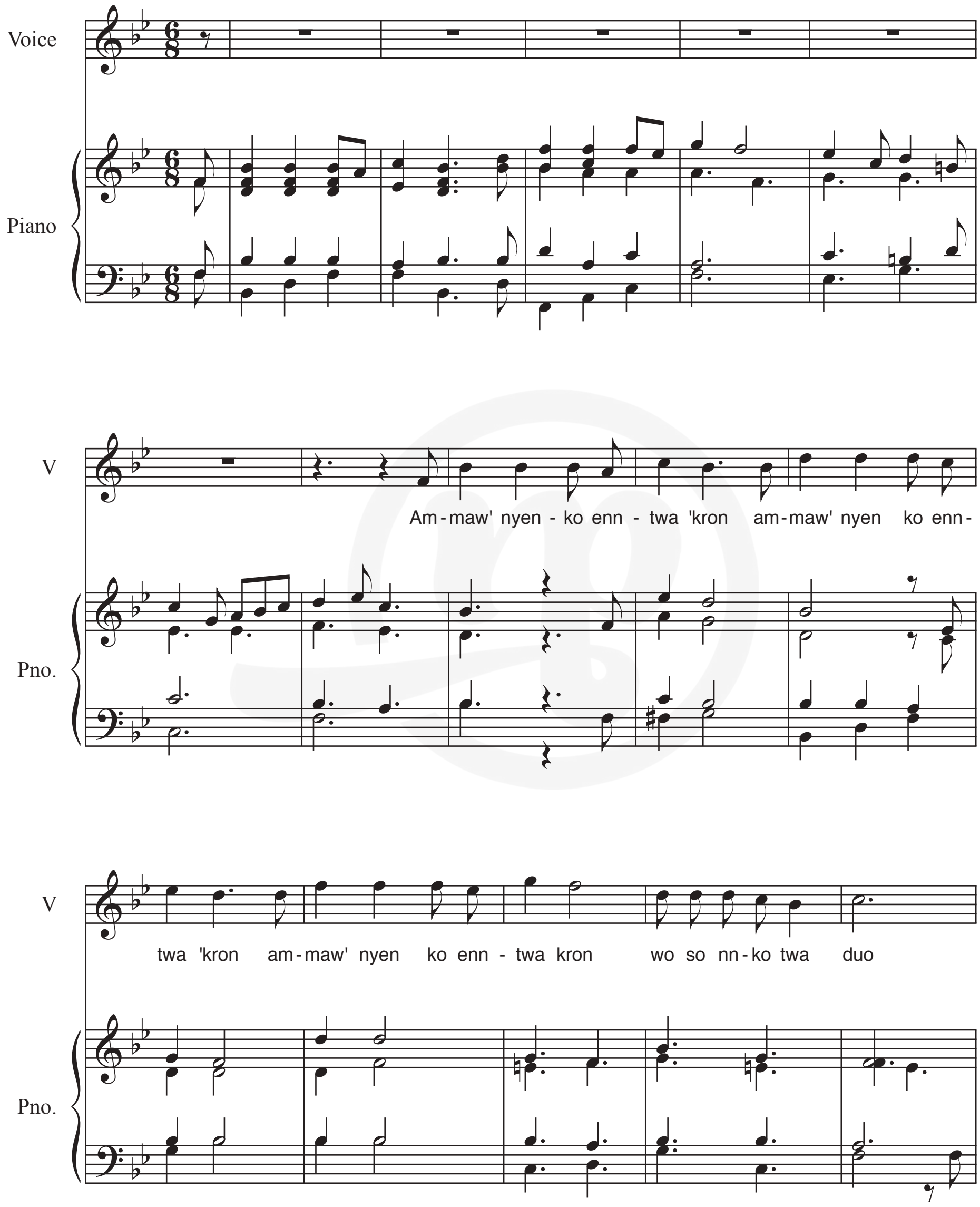

Voice Solo with Piano and Choruses for T.T.B.B | 26 

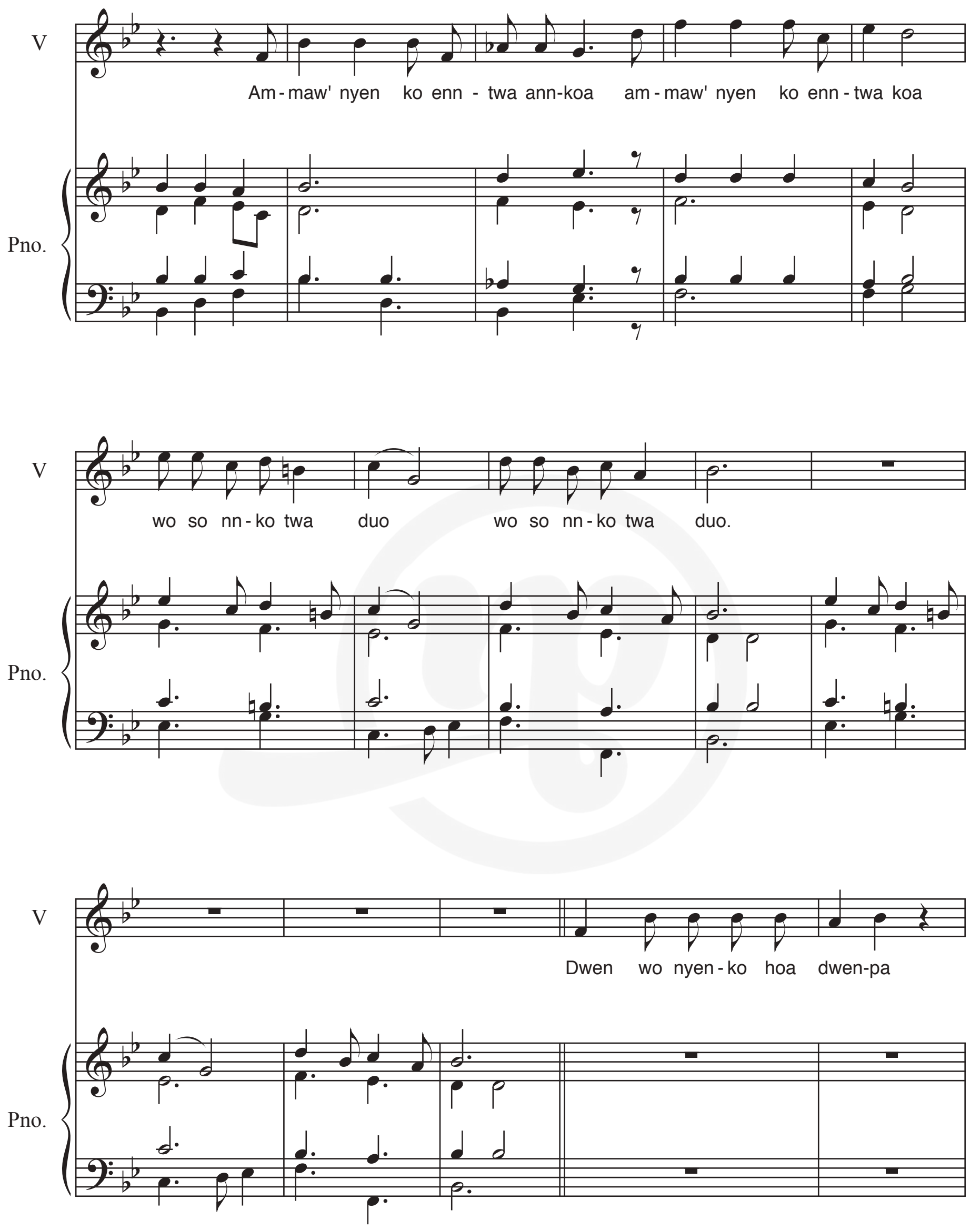

Voice Solo with Piano and Choruses for T.T.B.B | 27 

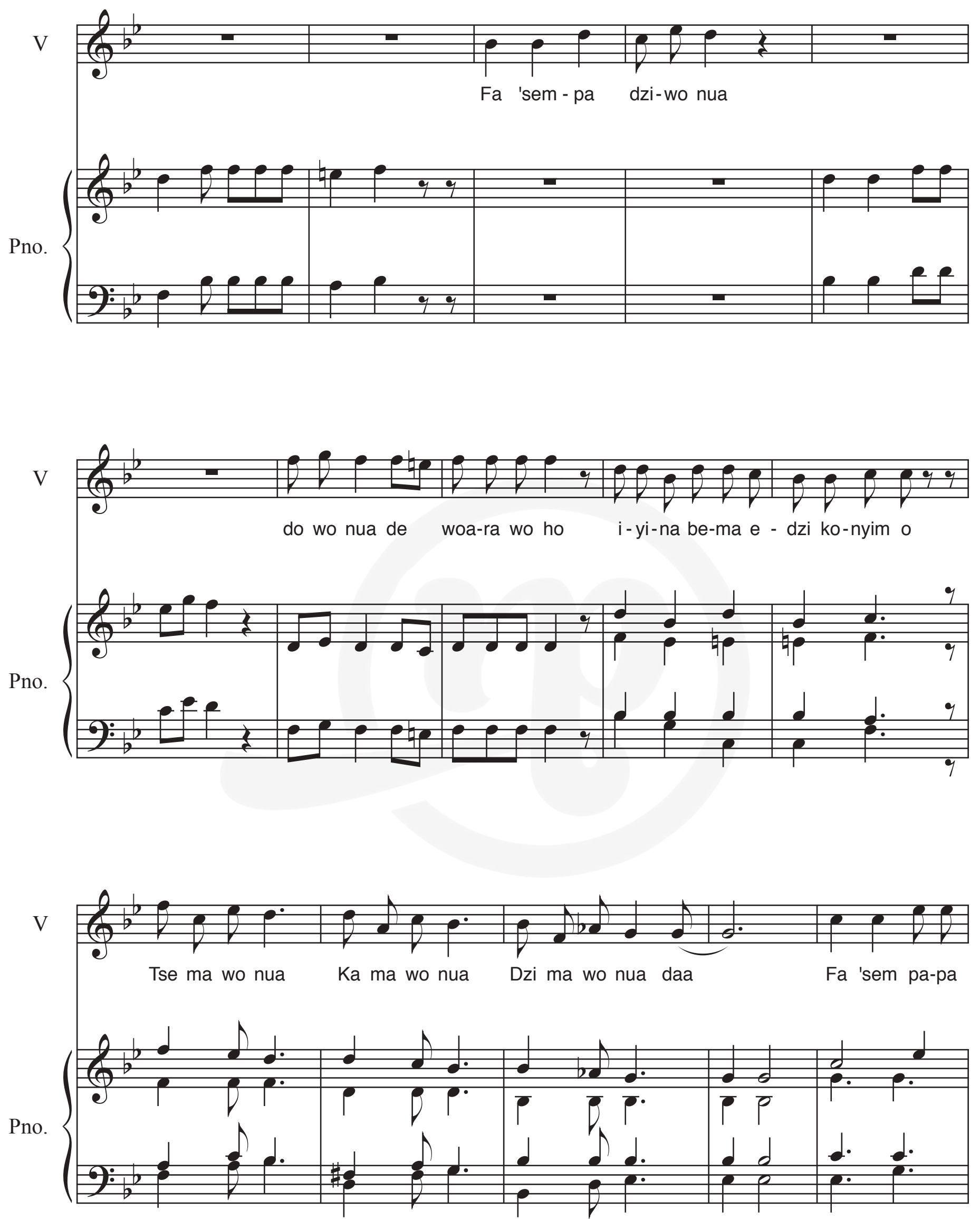

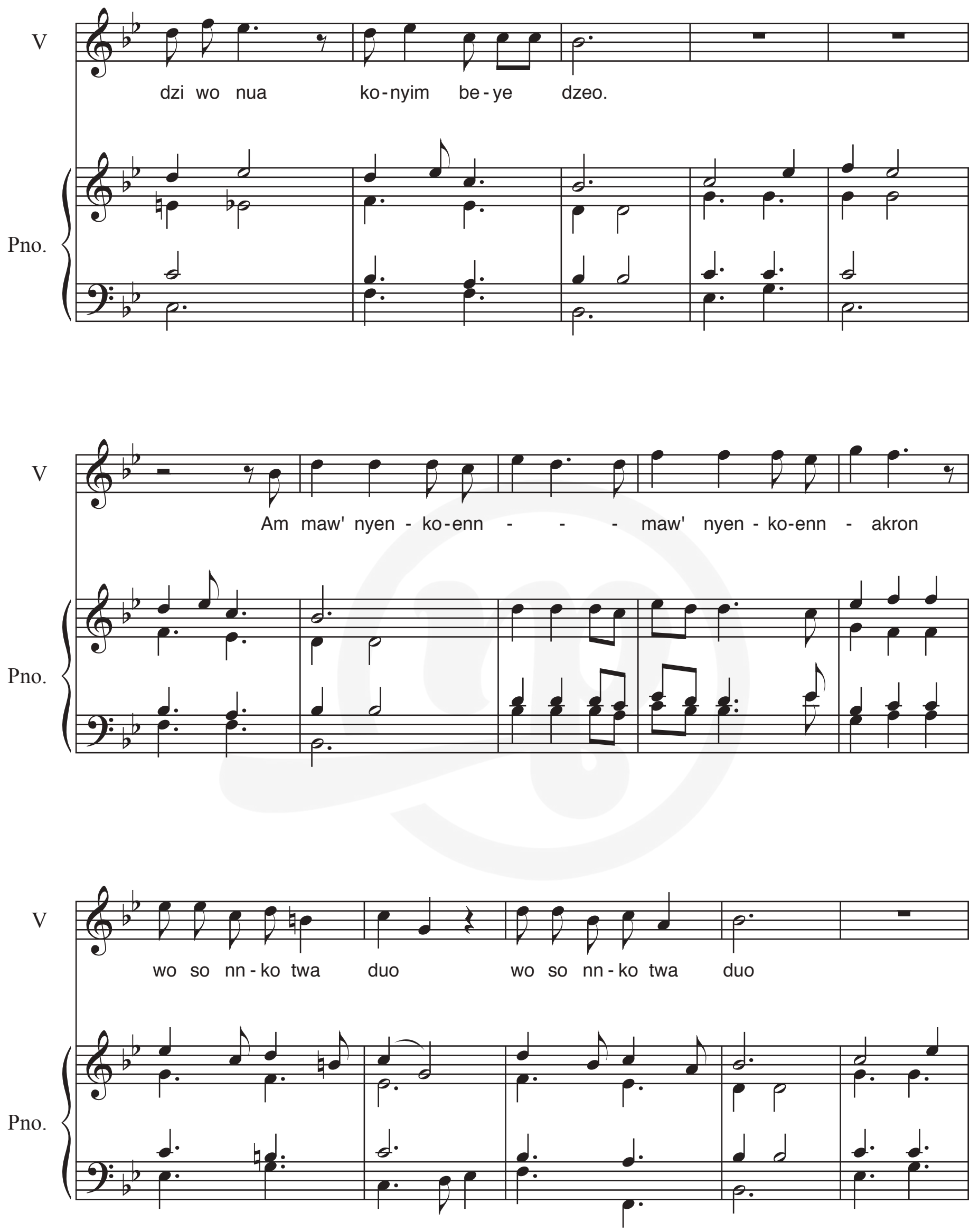

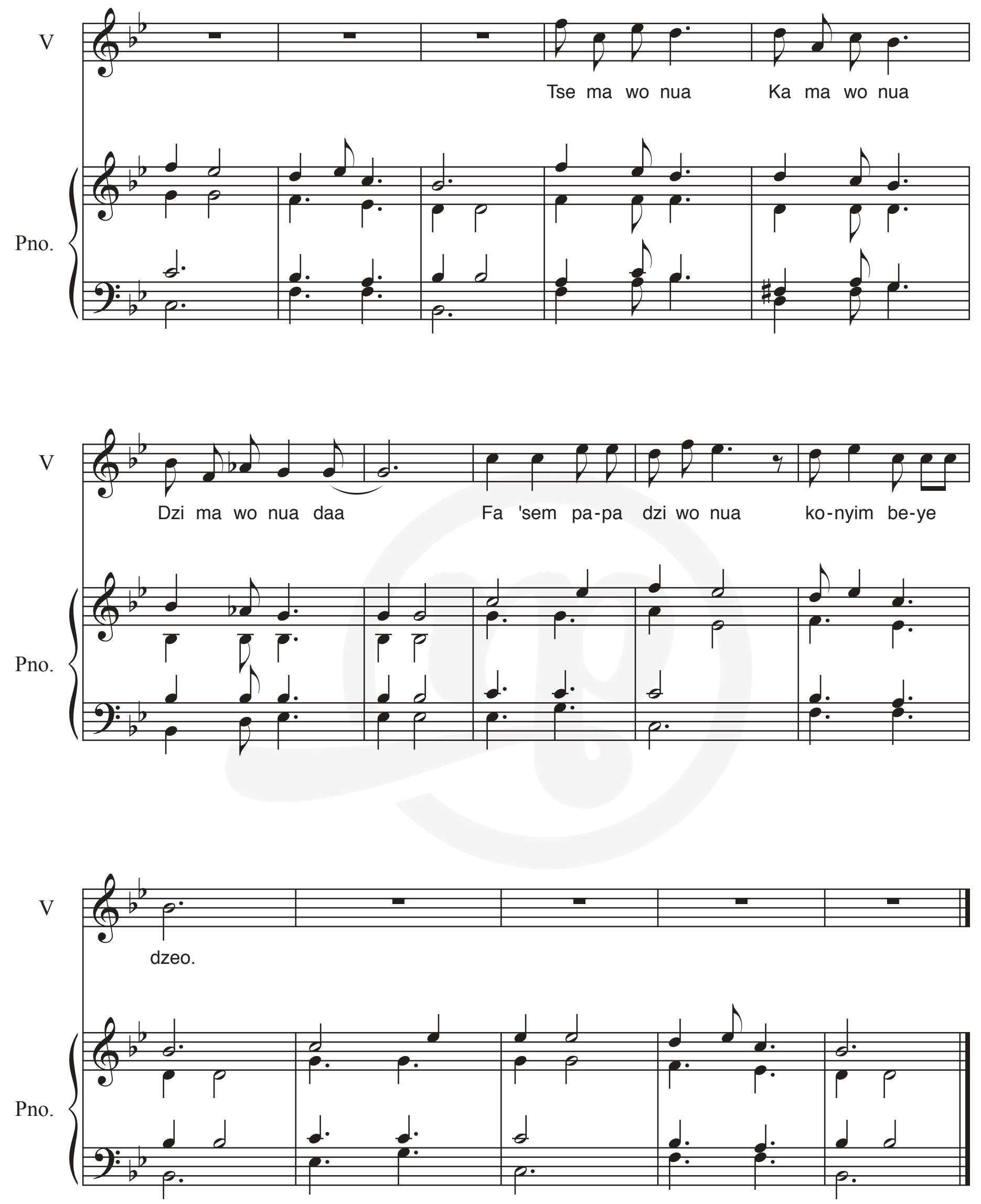


\section{M'BEDA NYAME ASE \\ ( I Shall Render Thanks To God)}

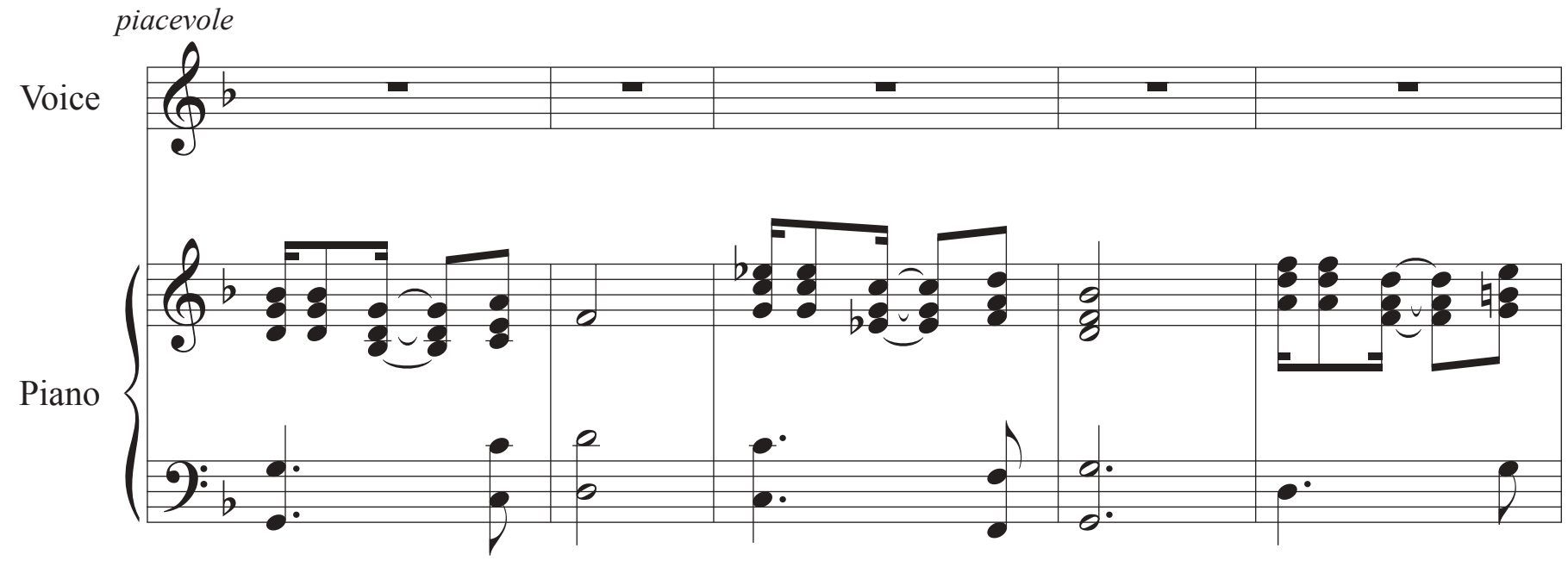

$\mathrm{Vc}$

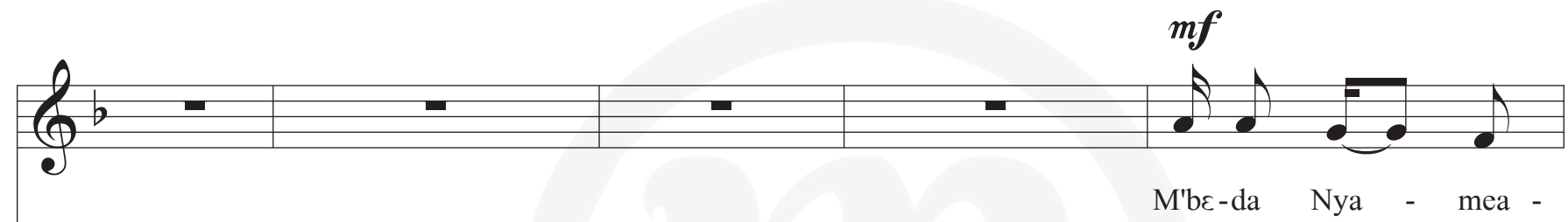

Pno.

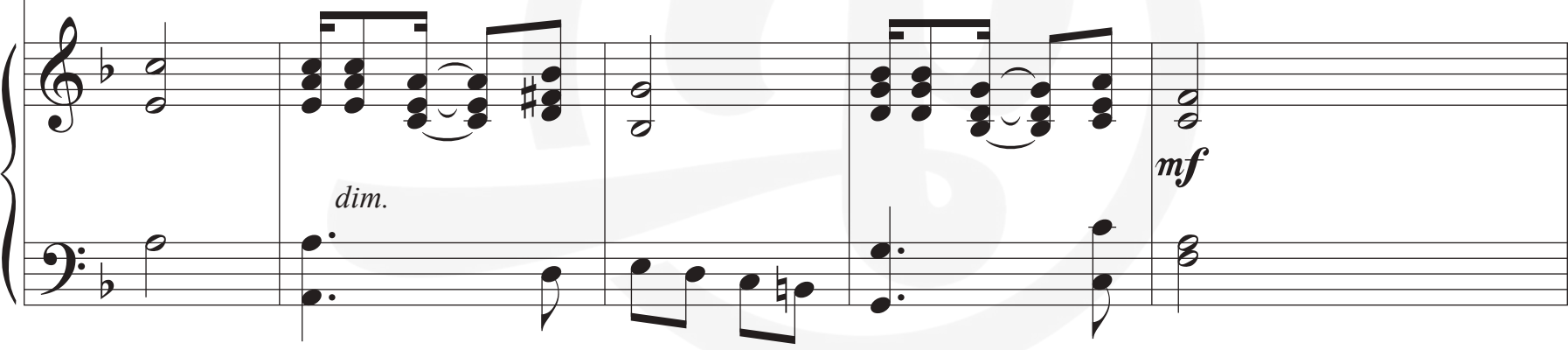

$\mathrm{Vc}$
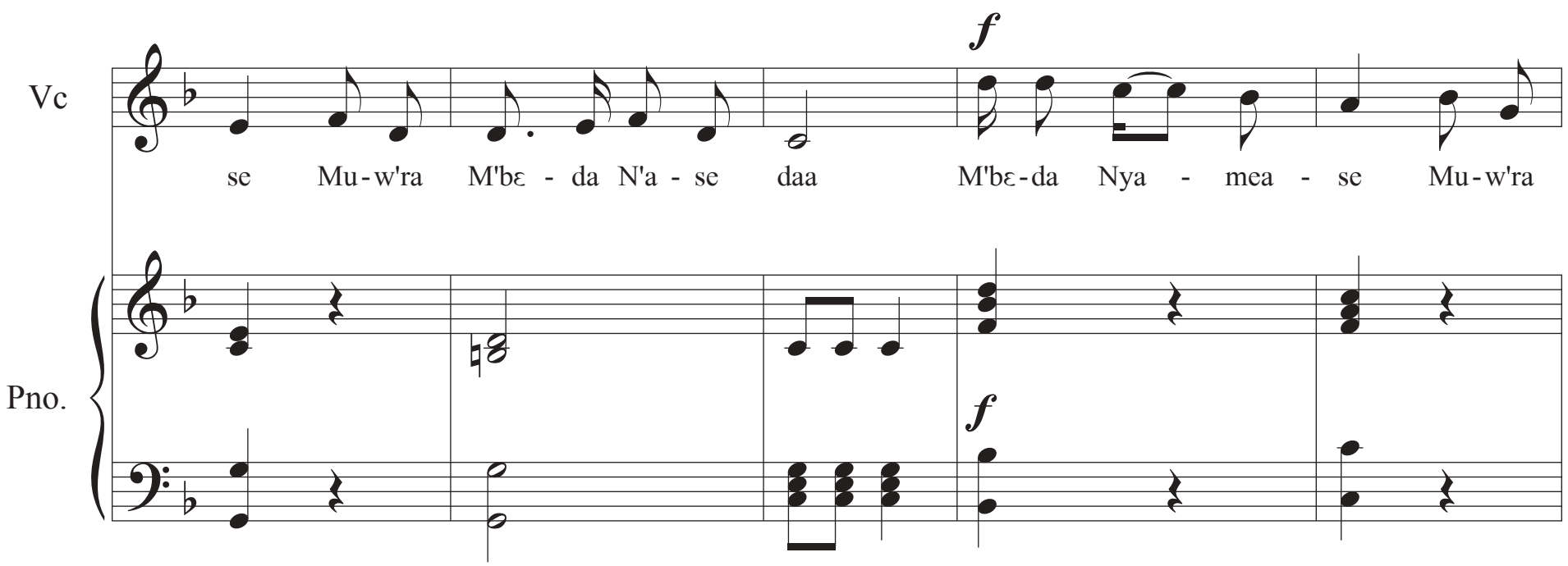

Voice Solo with Piano and Choruses for T.T.B.B | 31 

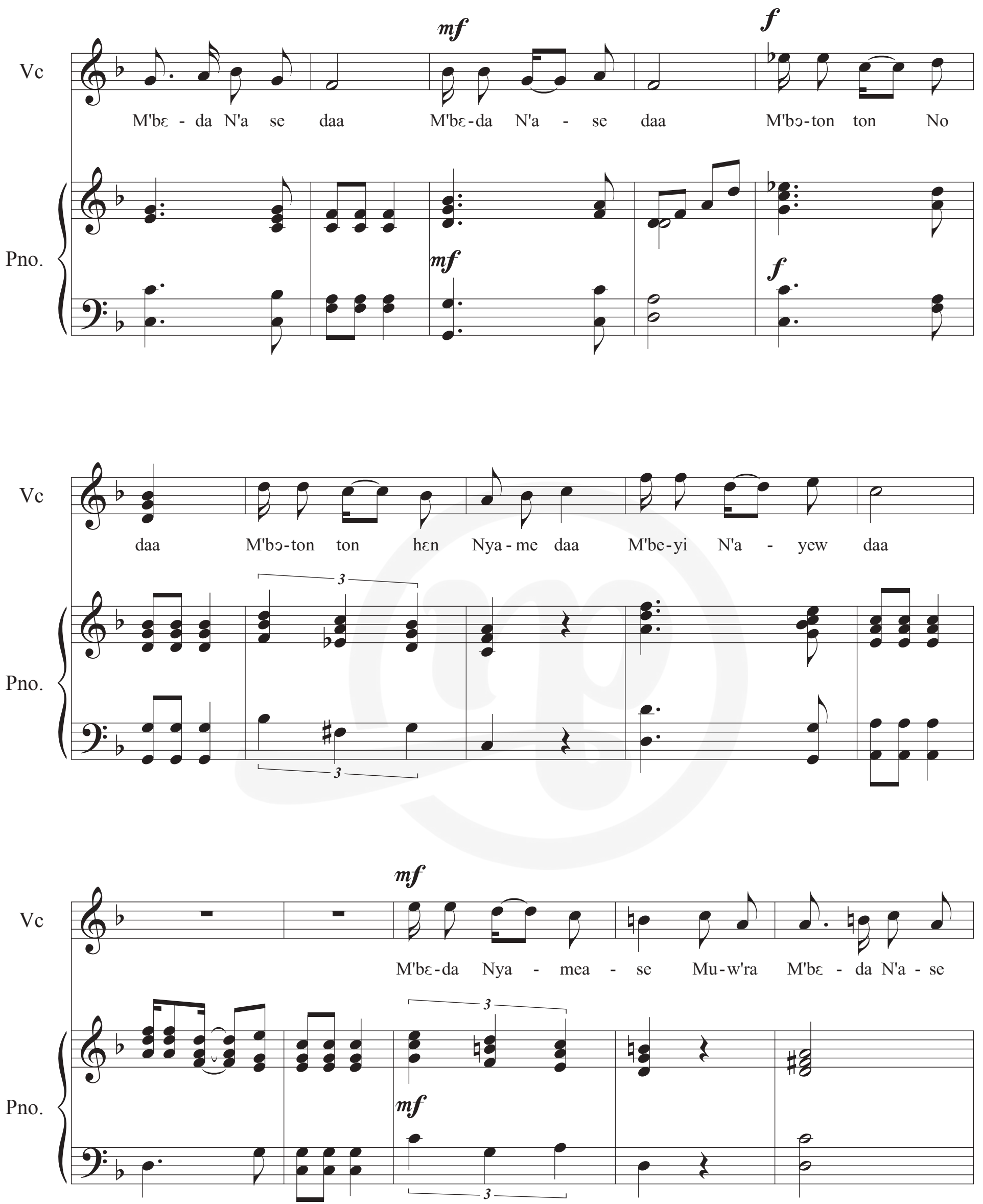

Voice Solo with Piano and Choruses for T.T.B.B | 32 
Vc
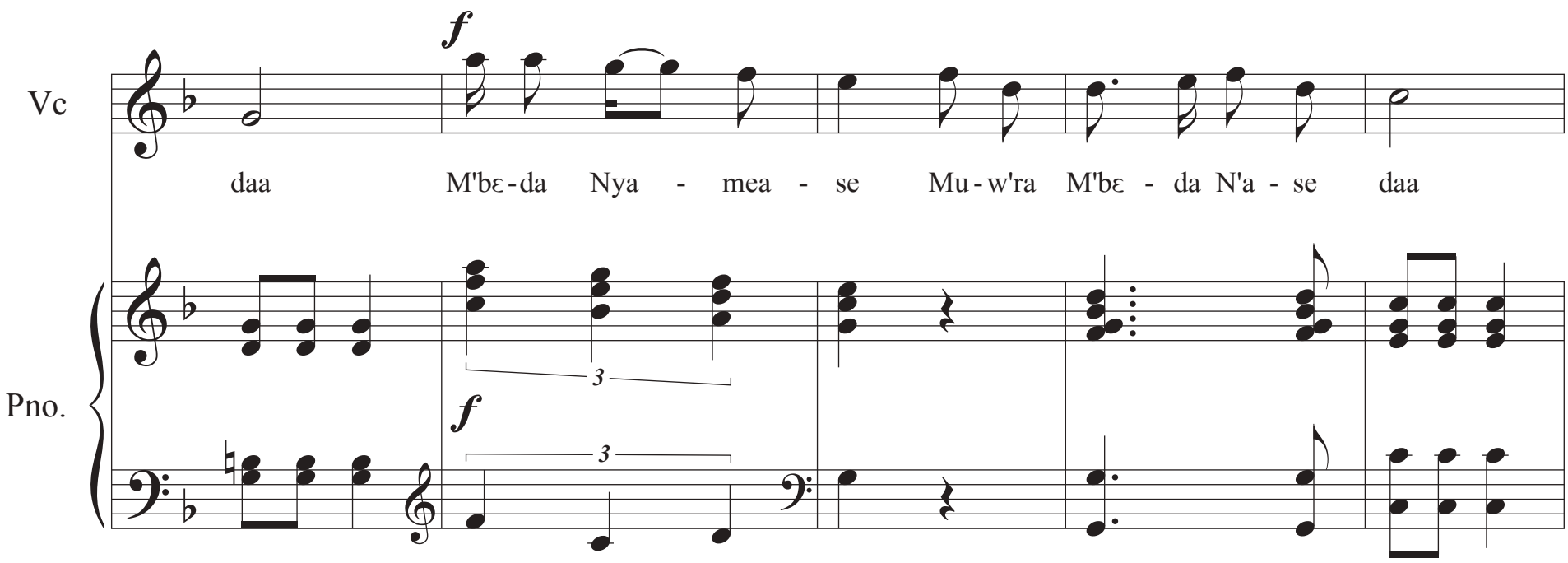

$\mathrm{Vc}$
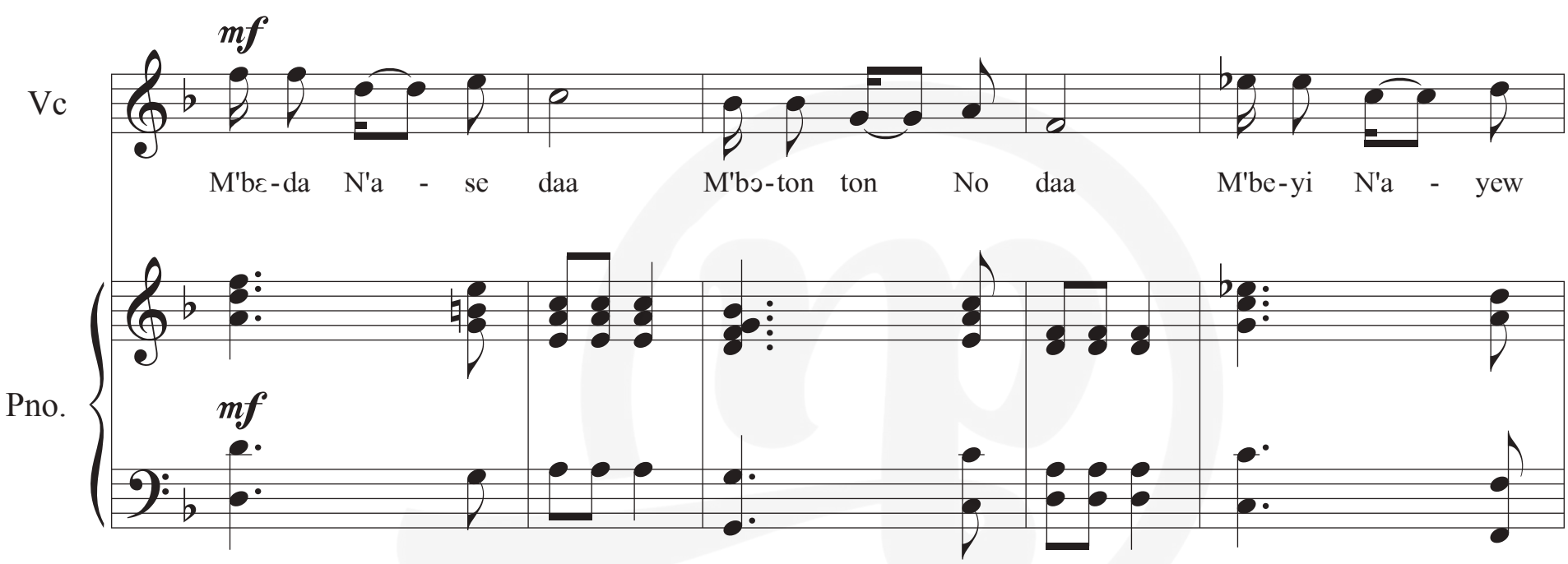

$\mathrm{Vc}$
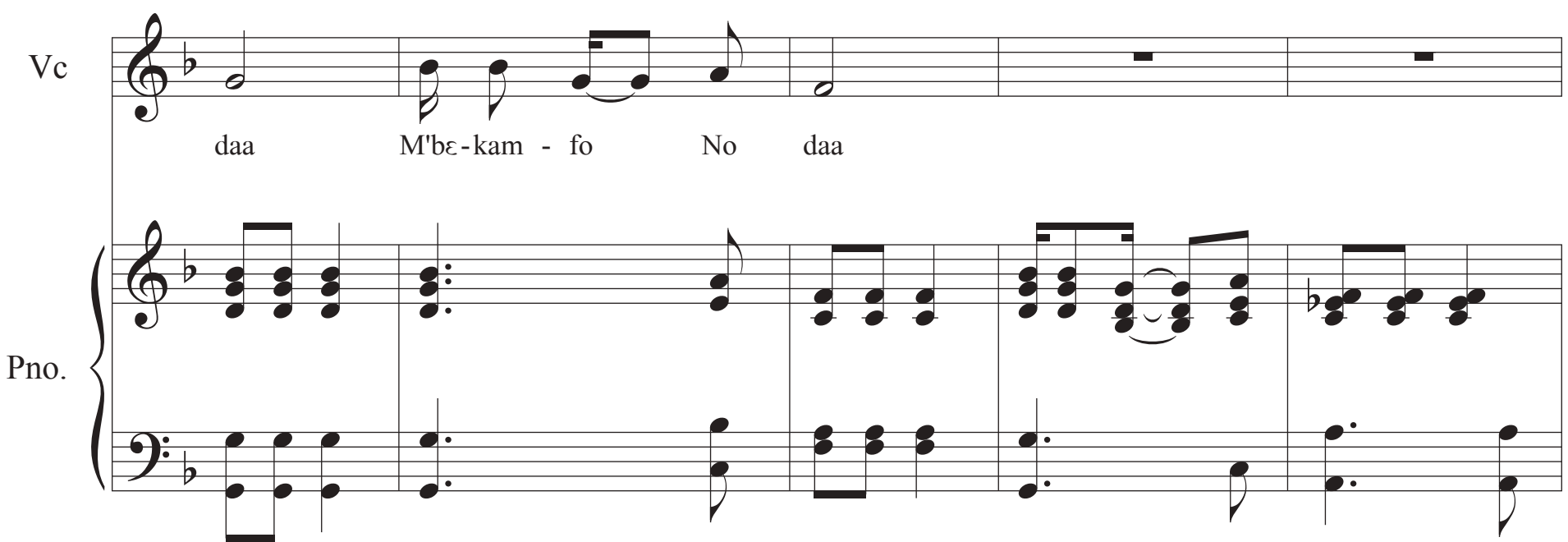

Voice Solo with Piano and Choruses for T.T.B.B | 33 

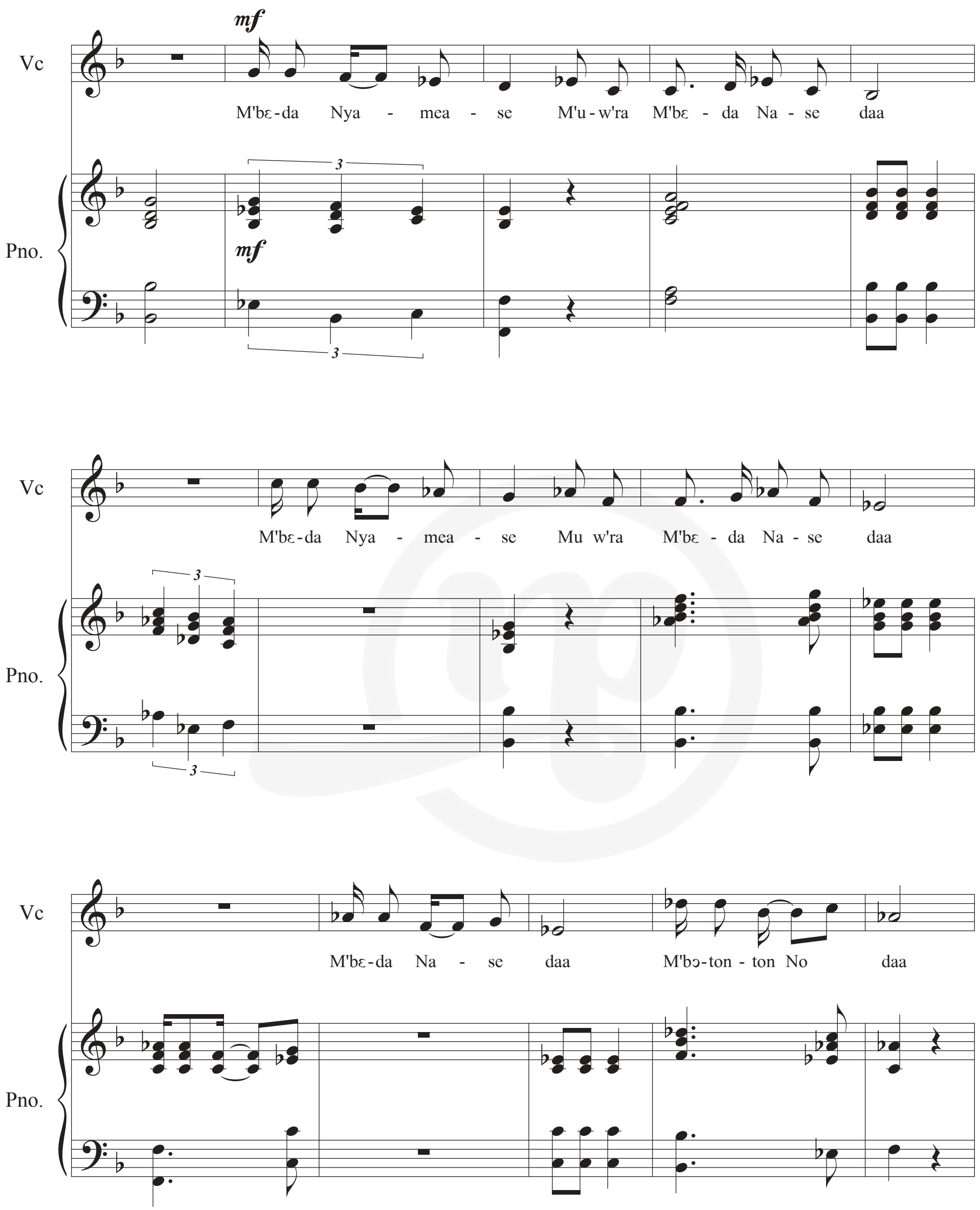

Voice Solo with Piano and Choruses for T.T.B.B | 34 

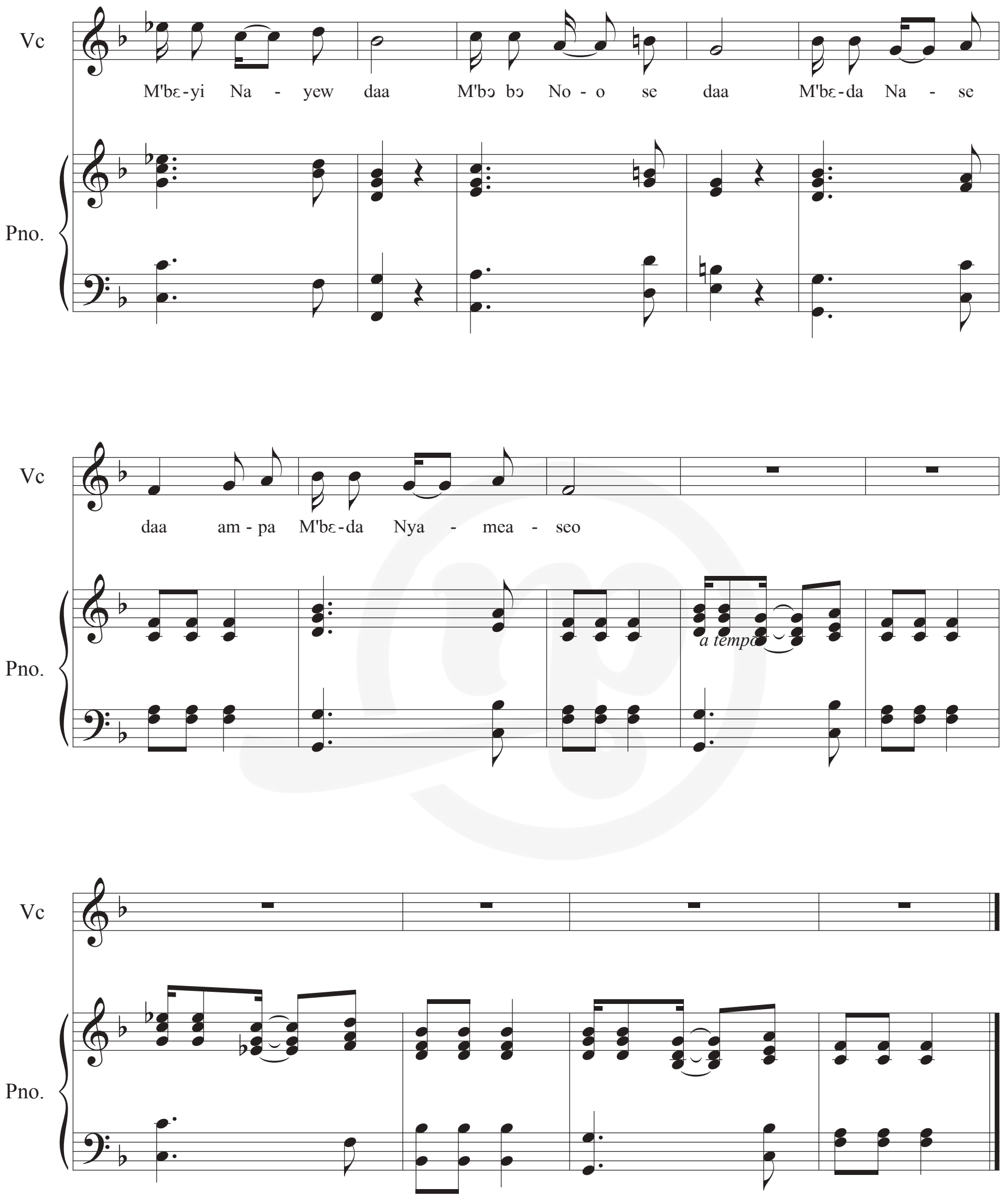


\section{ME NYAME, BRA O! \\ (Come! My Lord)}

Joshua Alfred Amuah
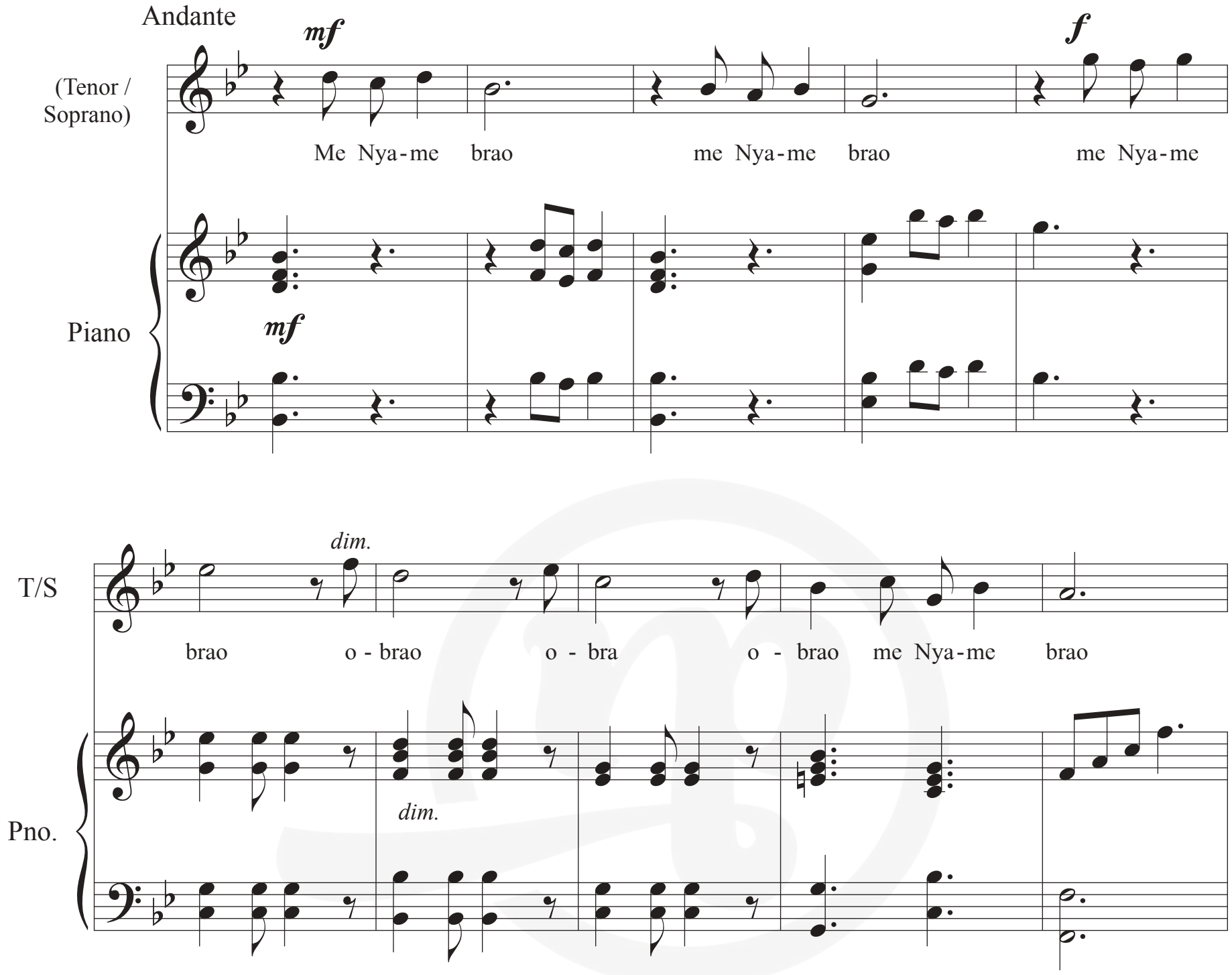

$\mathrm{T} / \mathrm{S}$

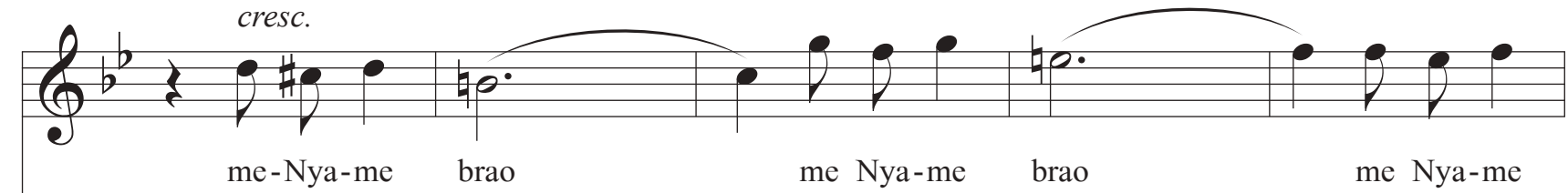

Pno.

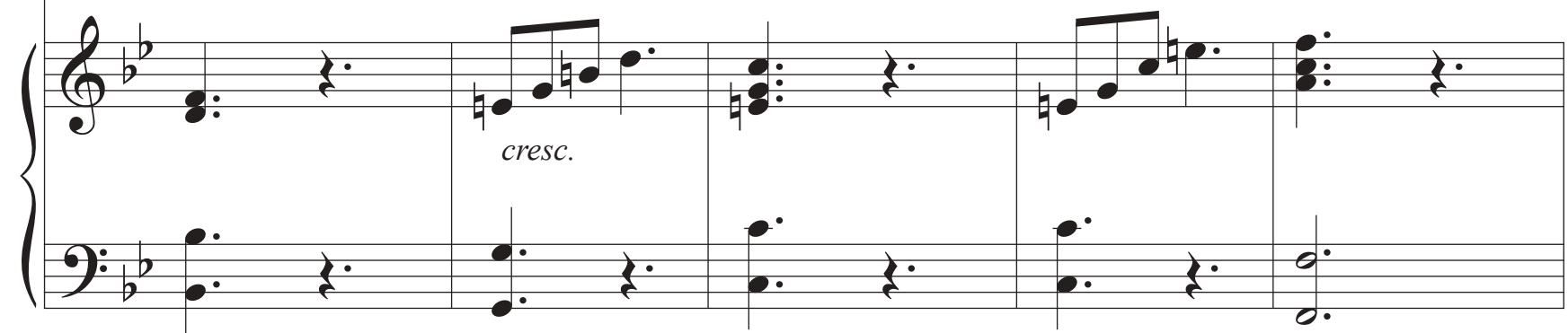

Voice Solo with Piano and Choruses for T.T.B.B | 36 

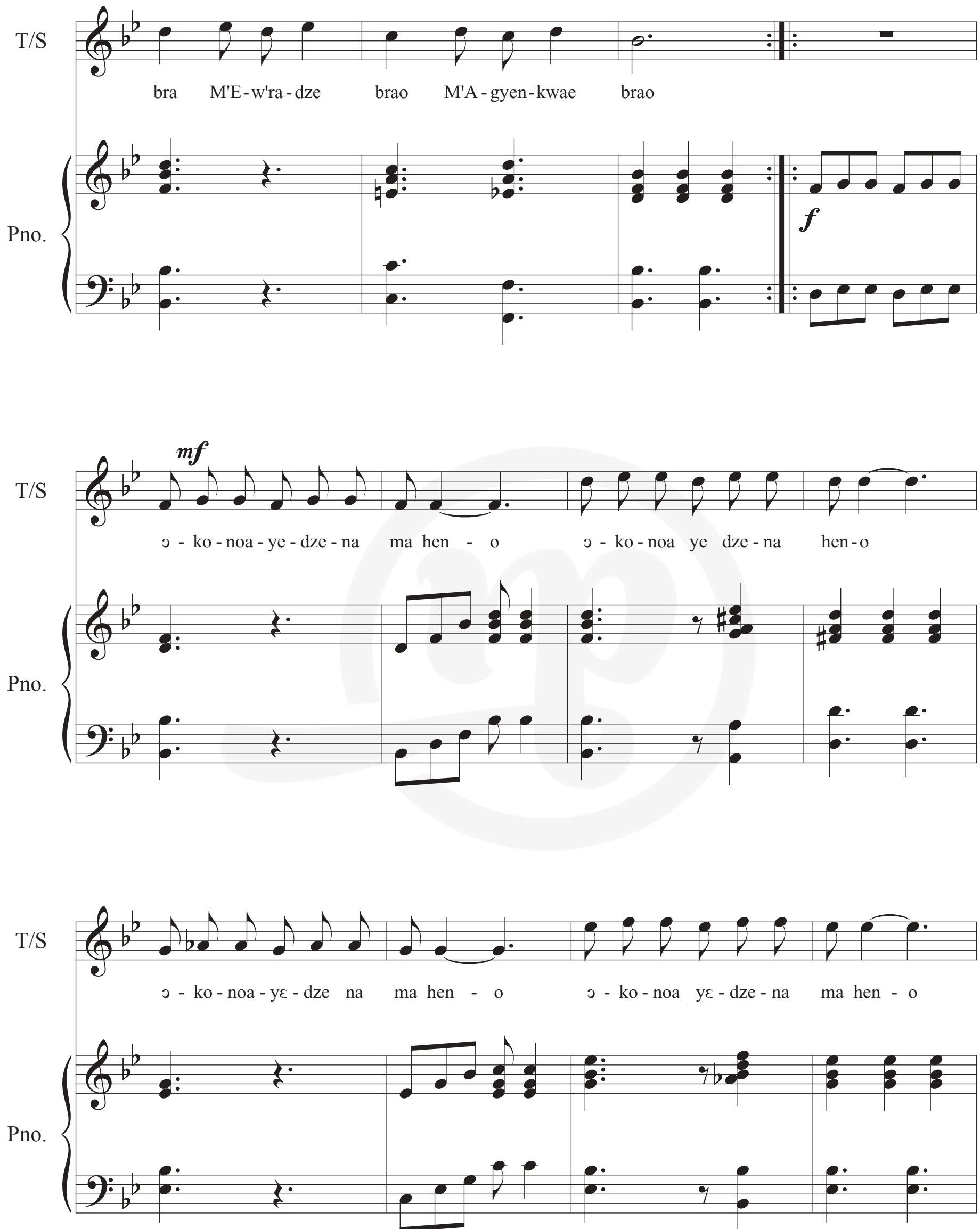

Voice Solo with Piano and Choruses for T.T.B.B | 37 

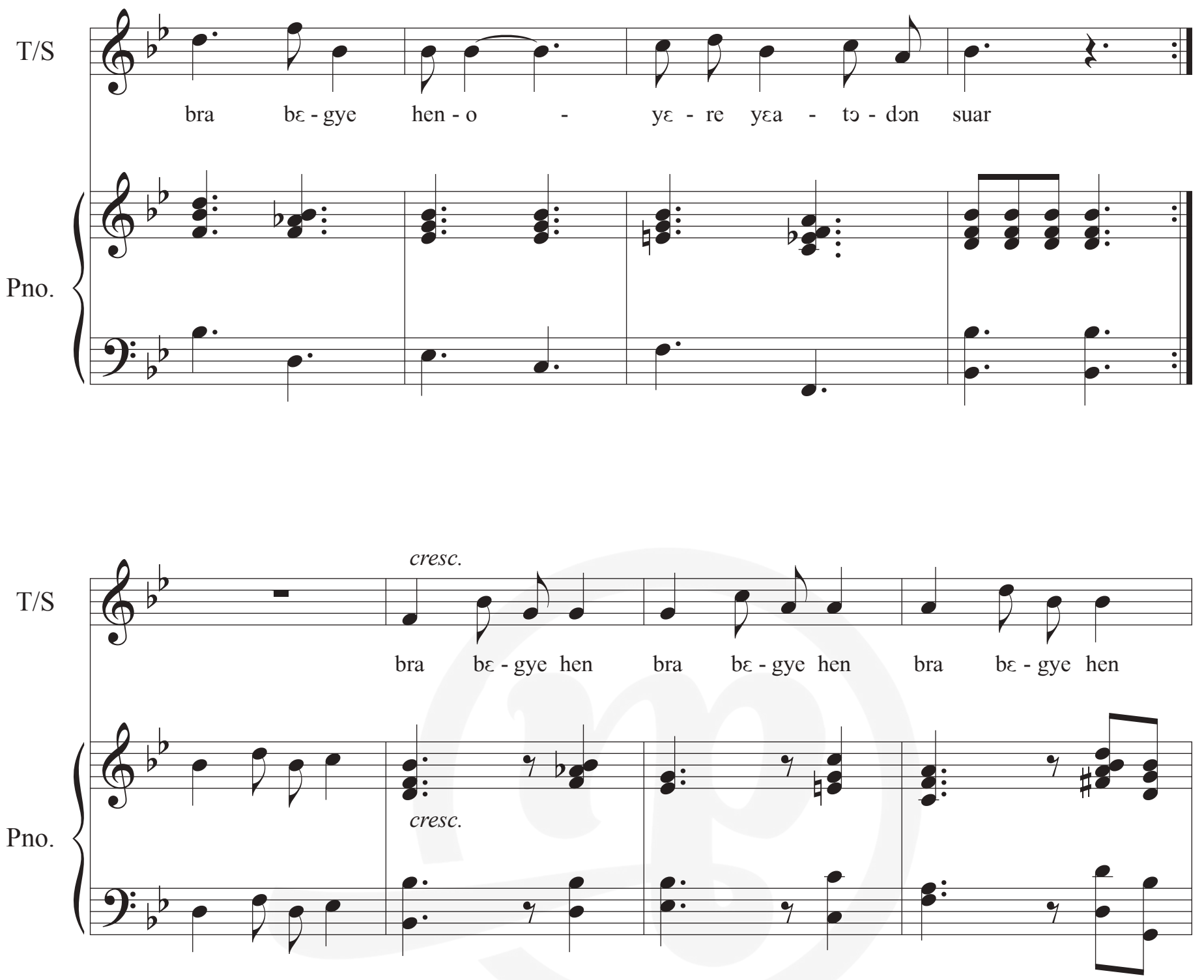

$\mathrm{T} / \mathrm{S}$
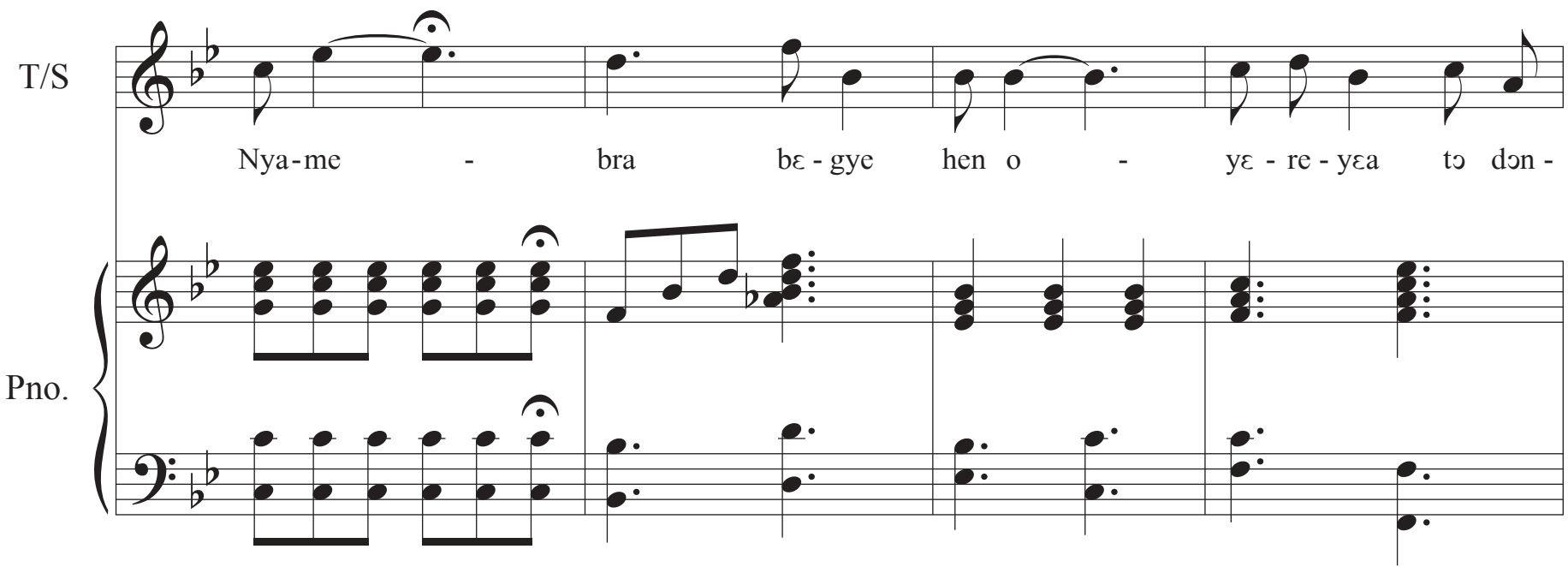

Voice Solo with Piano and Choruses for T.T.B.B | 38 

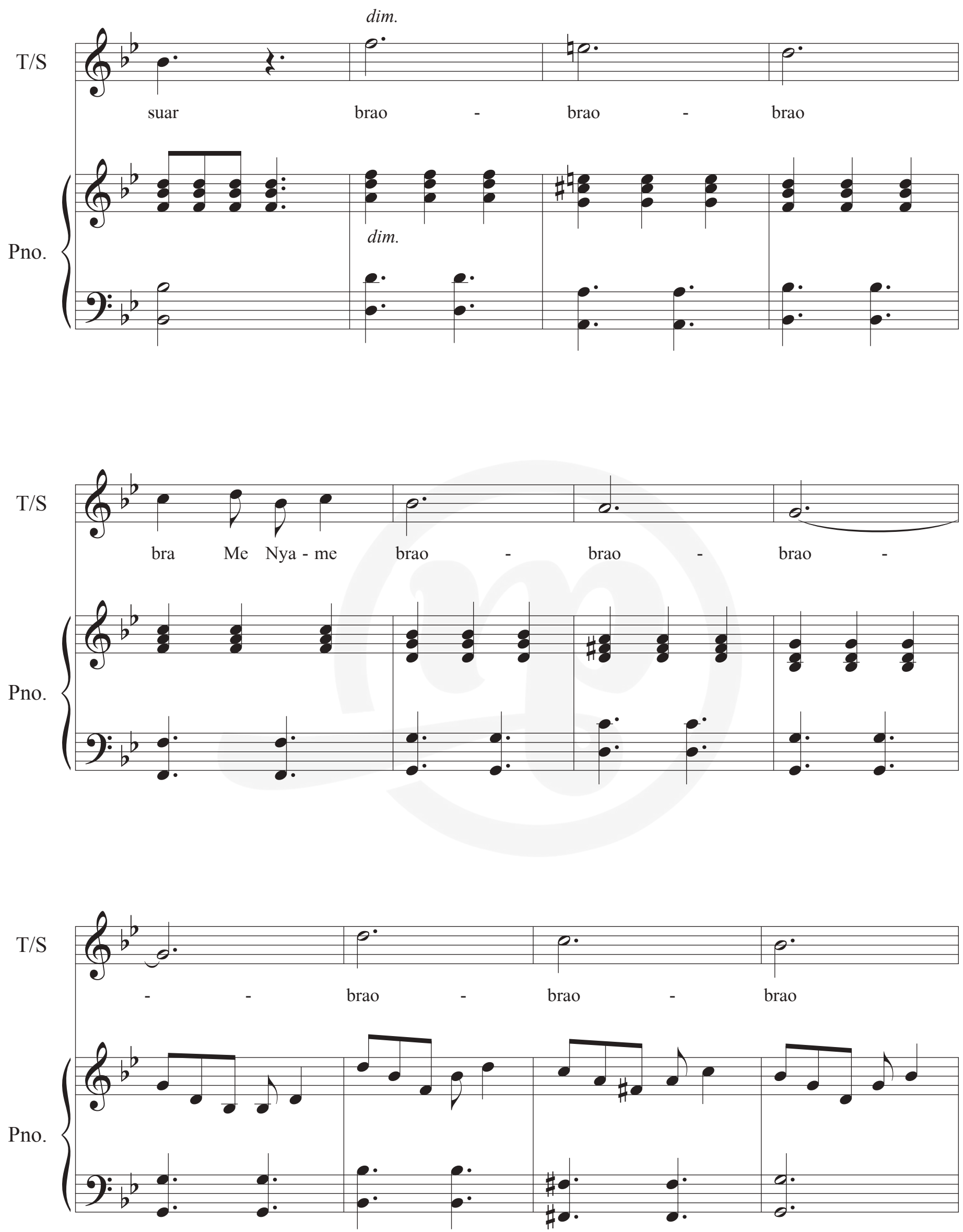

Voice Solo with Piano and Choruses for T.T.B.B | 39 
$\mathrm{T} / \mathrm{S}$
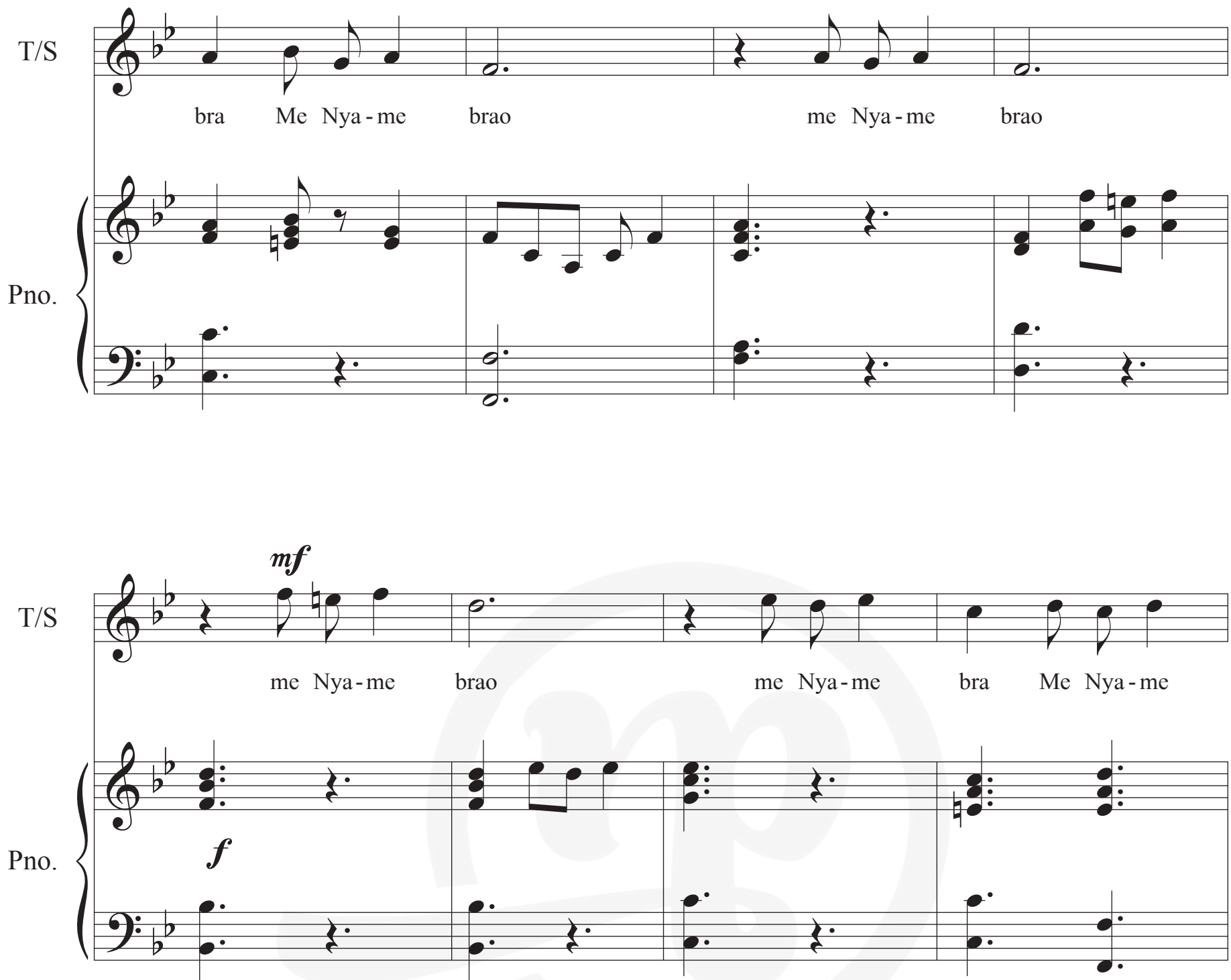

$\mathrm{T} / \mathrm{S}$
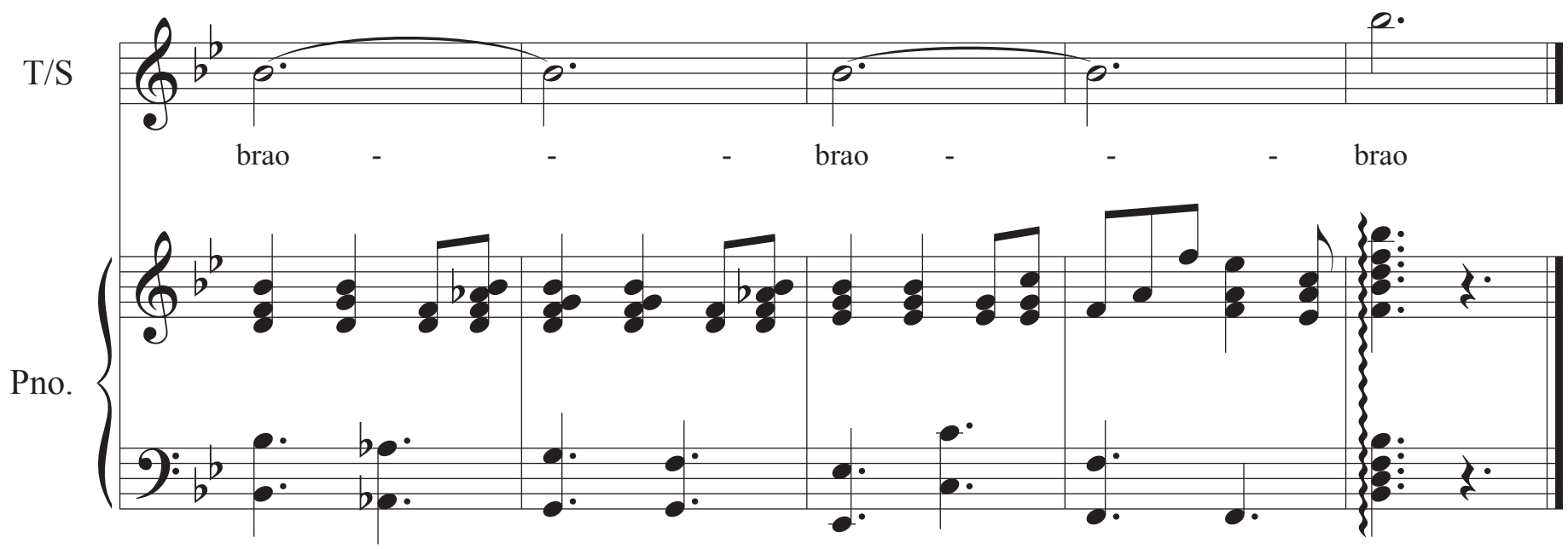

Voice Solo with Piano and Choruses for T.T.B.B | 40 
THIS COPY IS NOT FOR SALE

\section{BUEBUE SOR NTOKURA}

(Open The Windows Of Heaven)

Adapted from M. K. Amissah's SATB

Joshua A. Amuah

Arrangement for High Voice and Piano

12 th May 2019
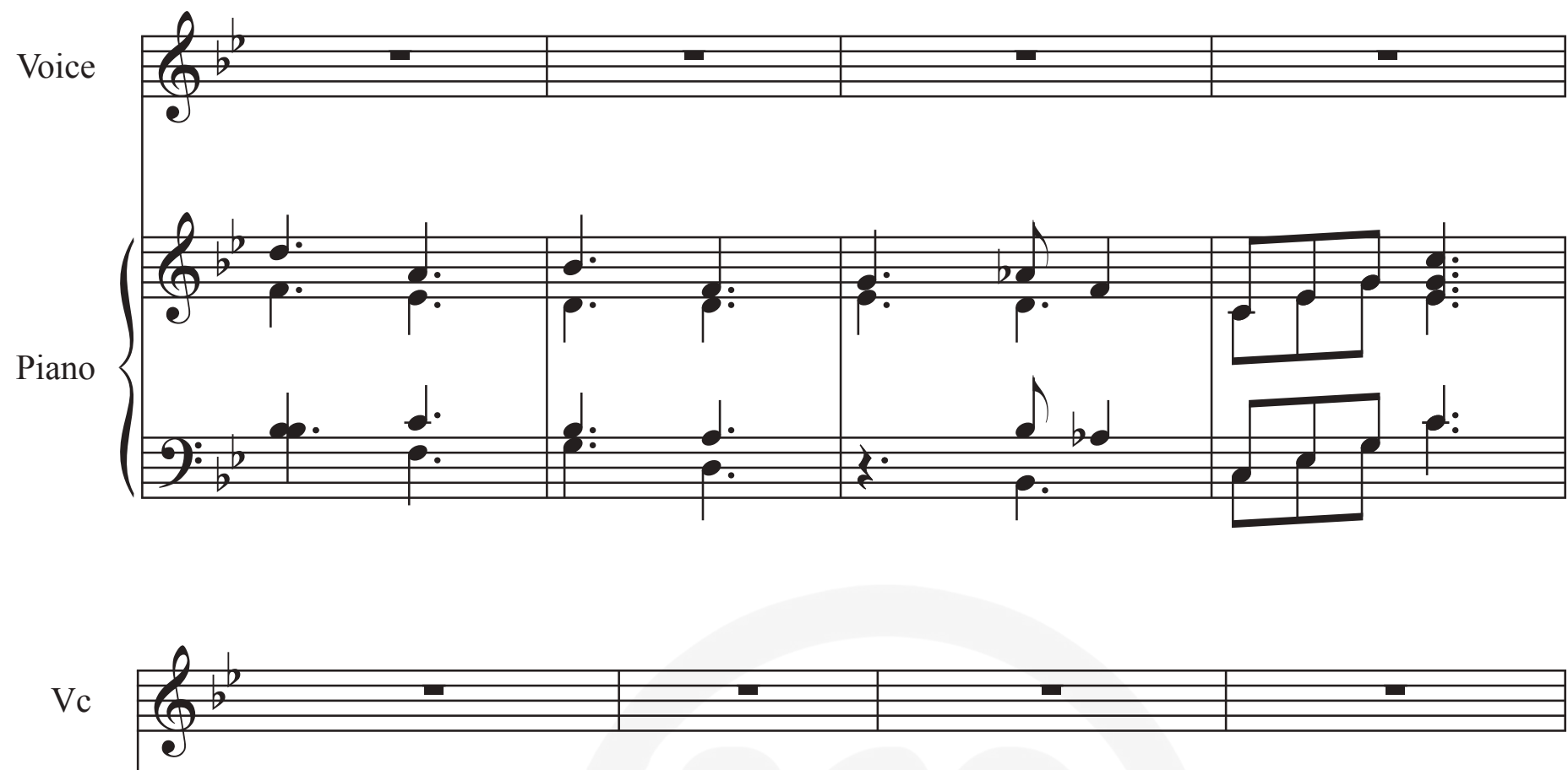

Pno.
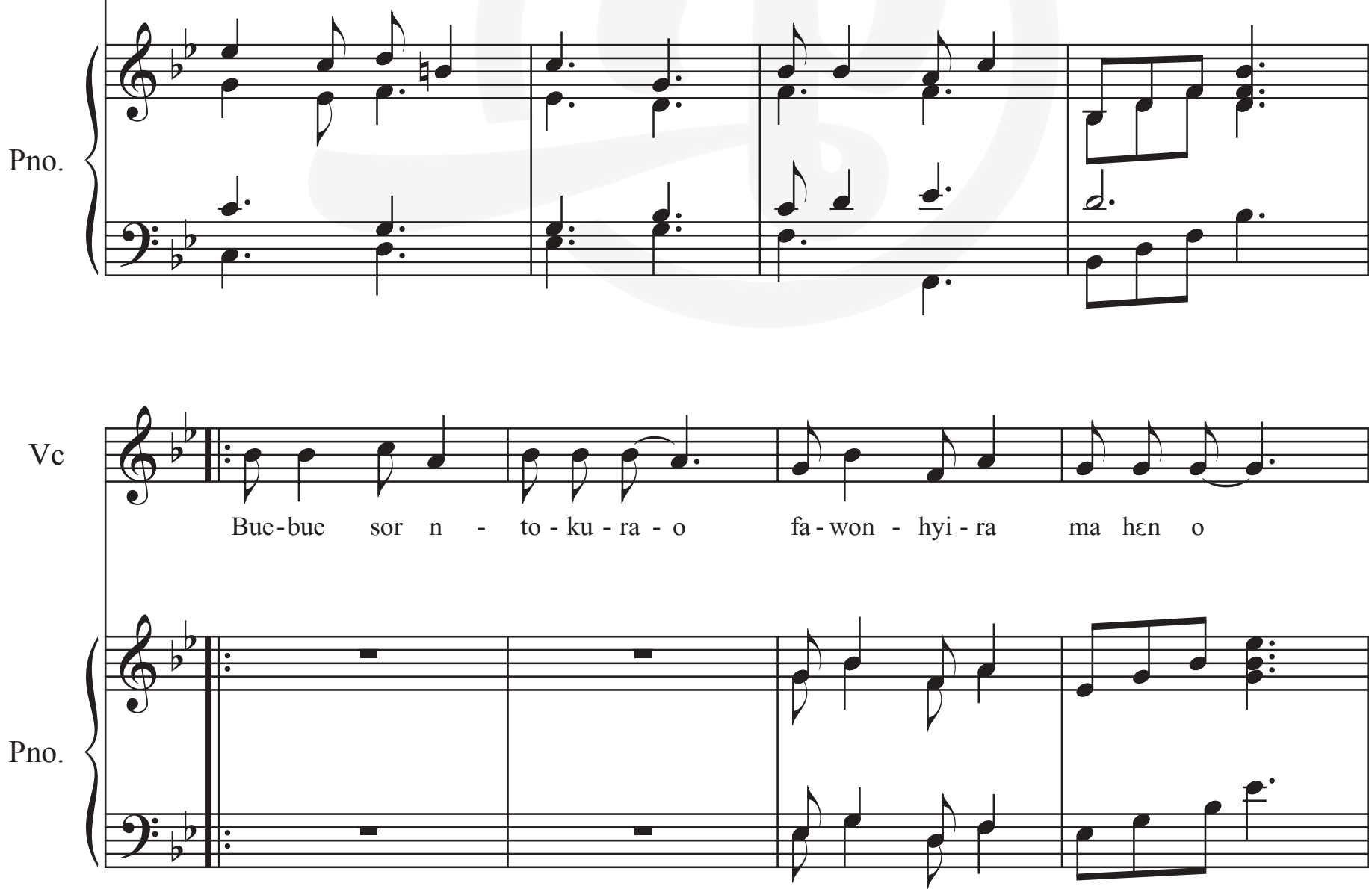

Voice Solo with Piano and Choruses for T.T.B.B | $4 \mathbf{1}$ 

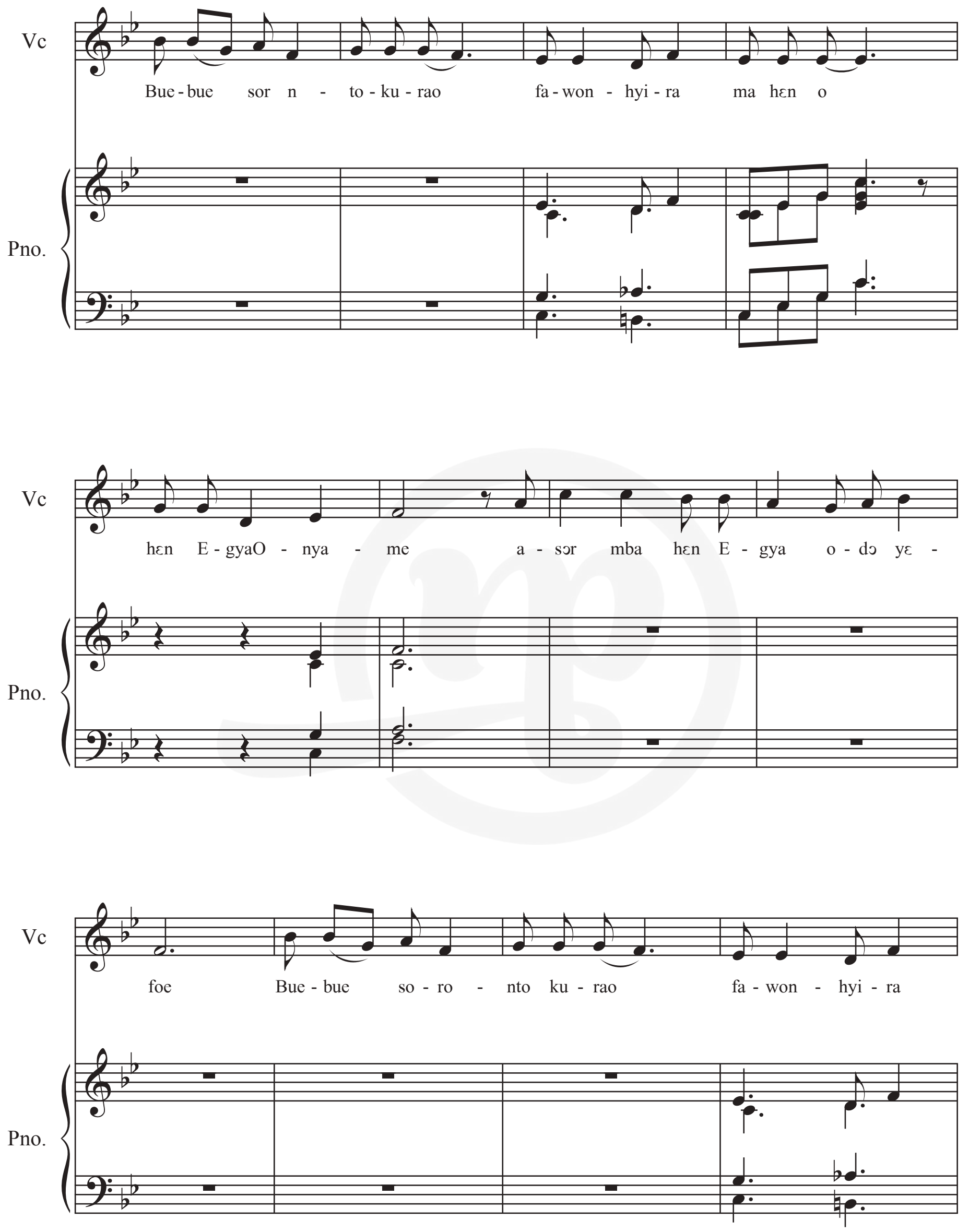

Voice Solo with Piano and Choruses for T.T.B.B | 42 

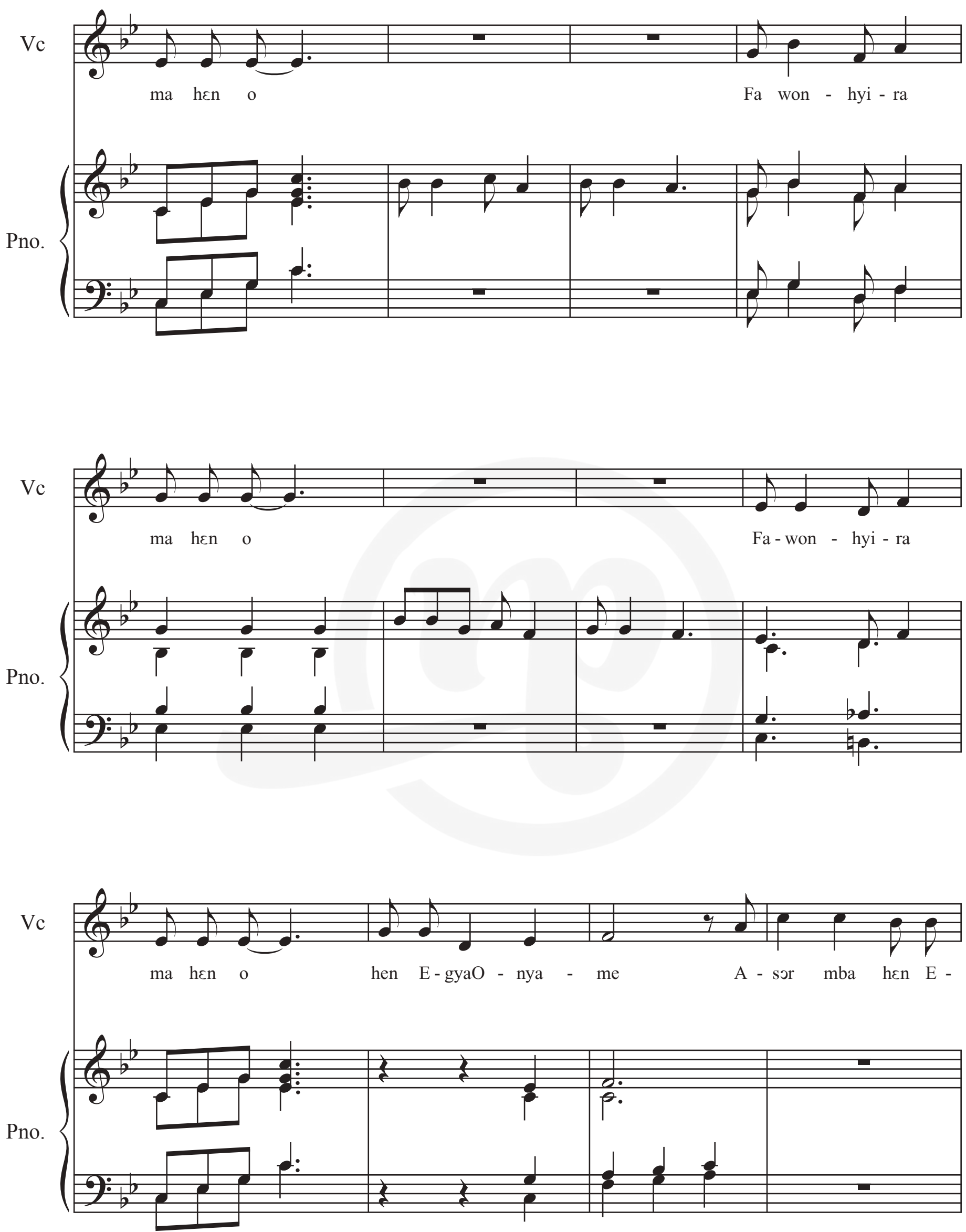

Voice Solo with Piano and Choruses for T.T.B.B | 43 

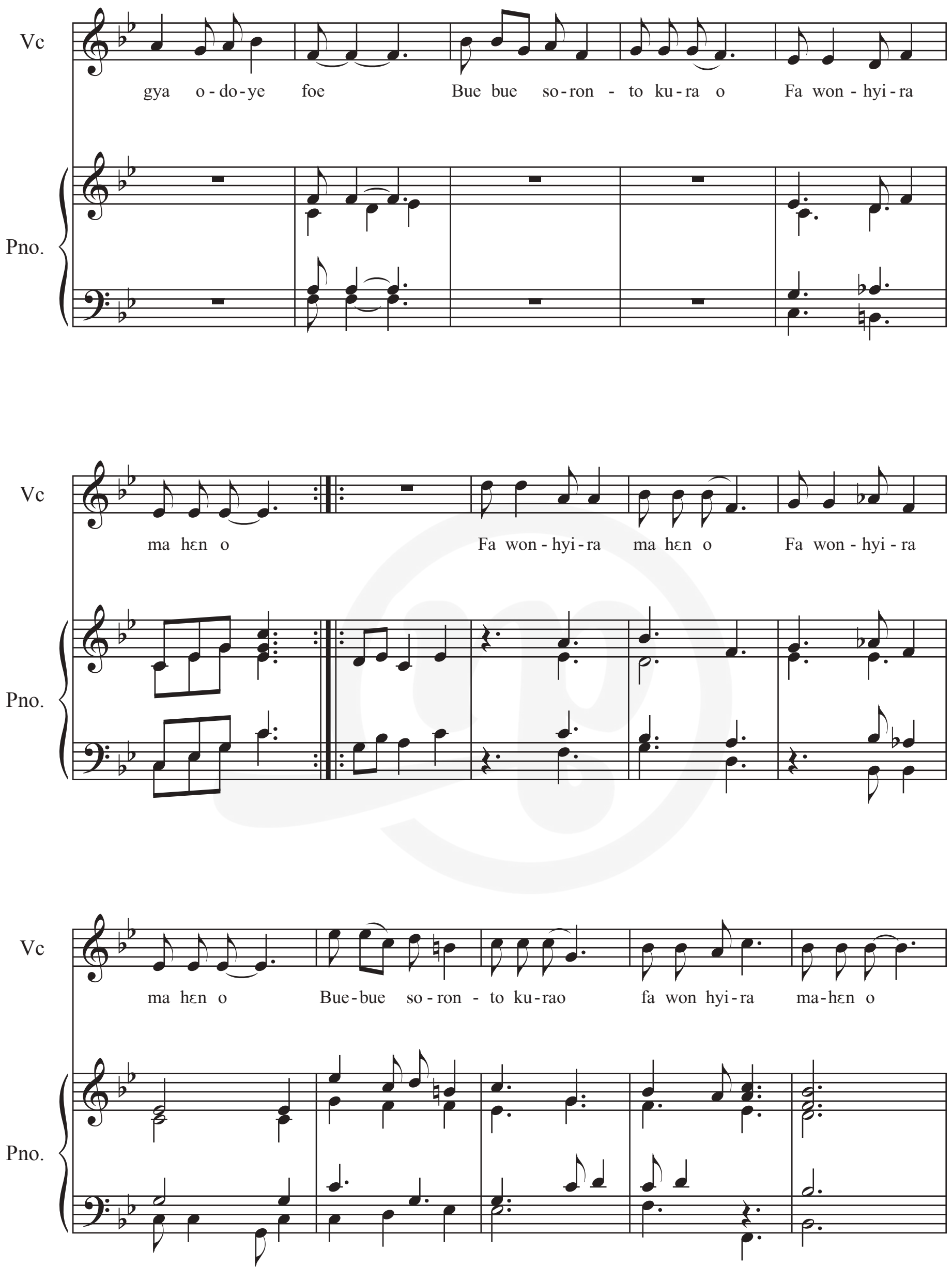

Voice Solo with Piano and Choruses for T.T.B.B | 44 

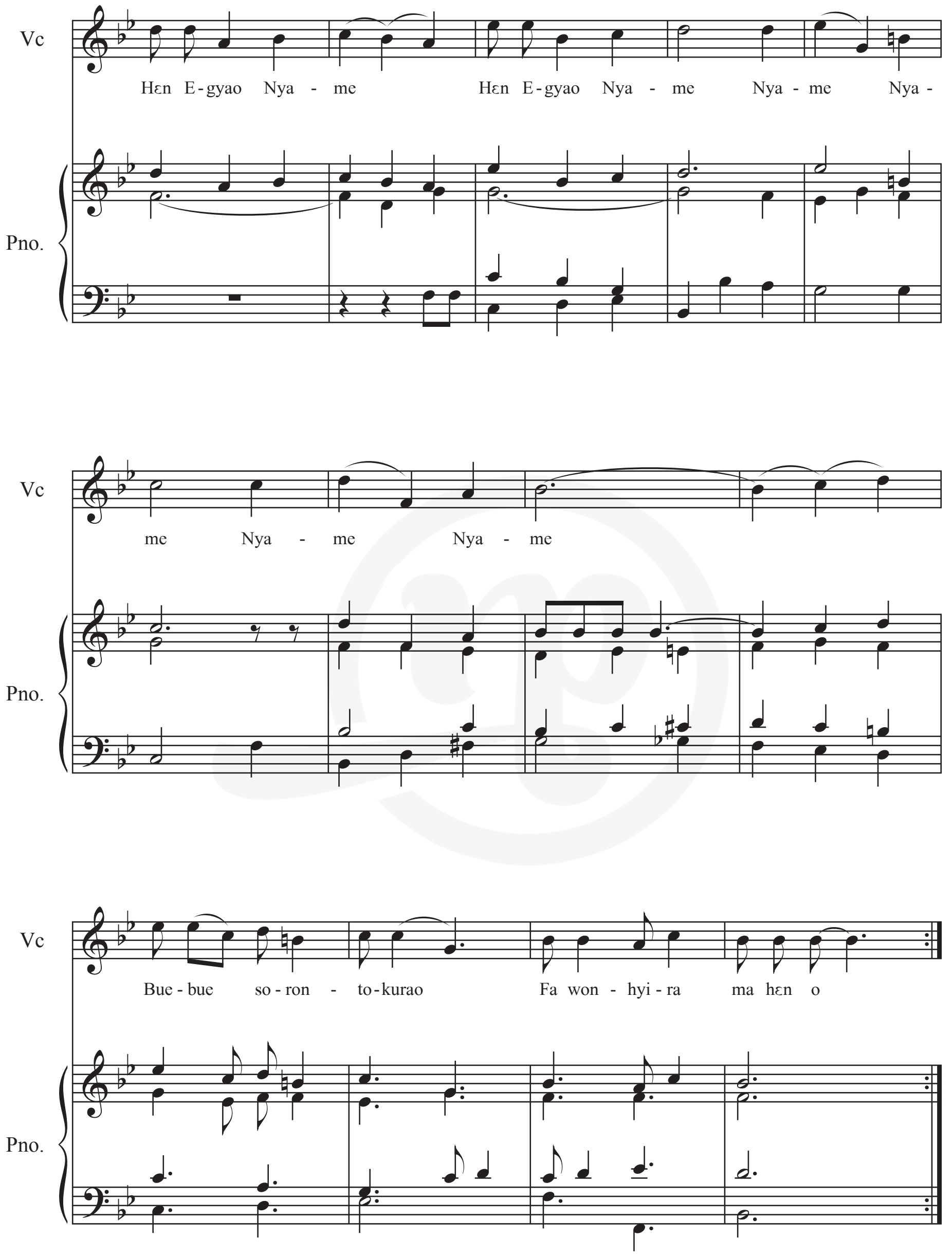

Voice Solo with Piano and Choruses for T.T.B.B | 45 


\section{WOMMA YENKO DO NSOM \\ (Let us continue to worship)}

Tenor 1

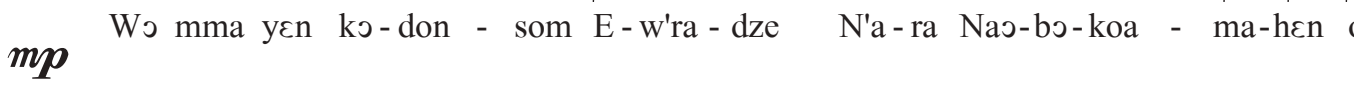

Bass 2

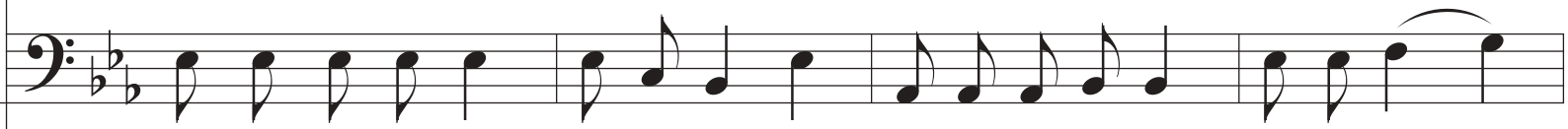
mp Wэ mma yen kэ-don - som E-w'ra-dze N'a-ra Naэ-bっ-koa - ma-hєn o -
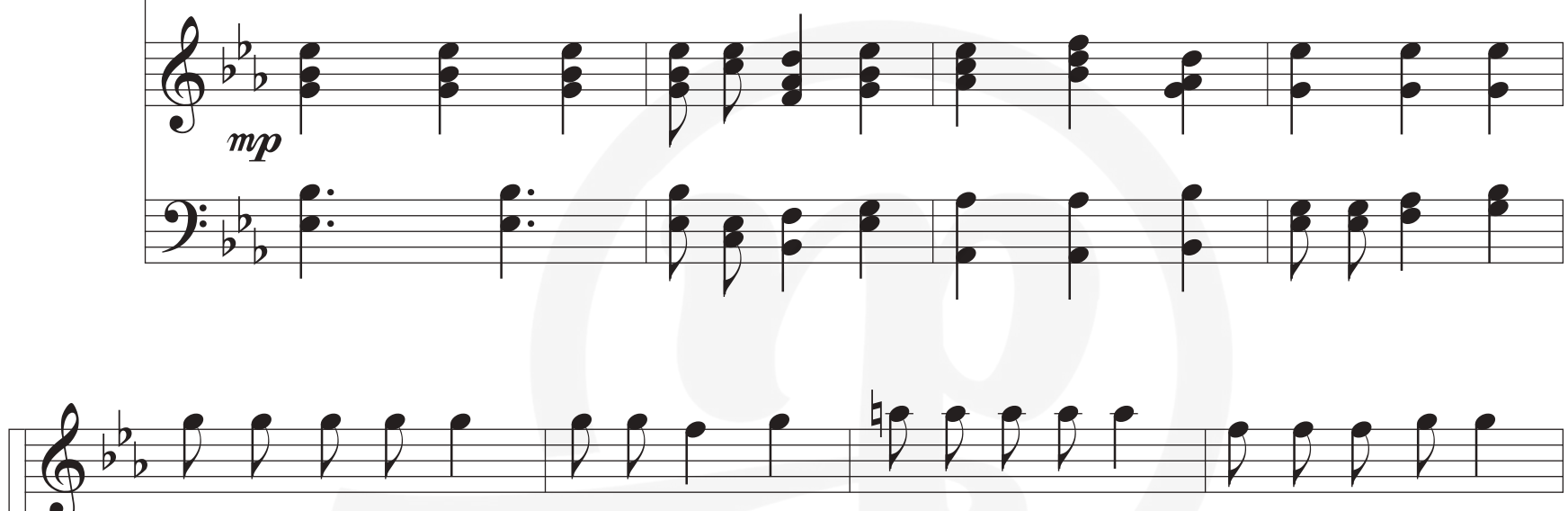

$8 \boldsymbol{m} \boldsymbol{f}$ wo mma yen ko-don - som E-w'ra - dze N'a-ra Naว-be ka - ama hen o - be ka

T 2

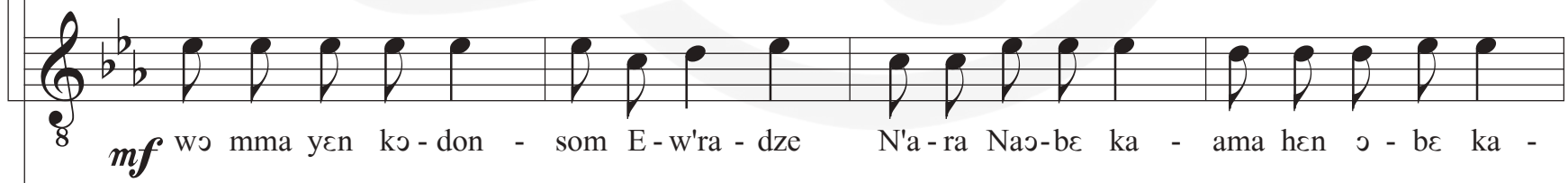

B 1

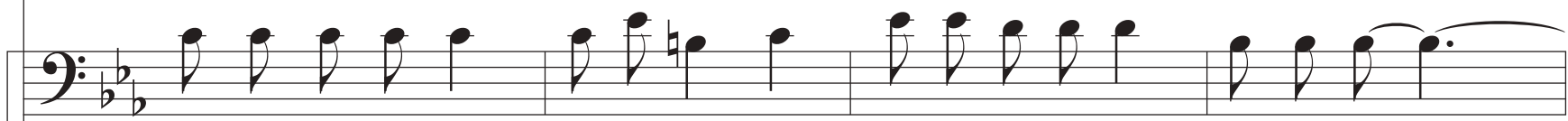

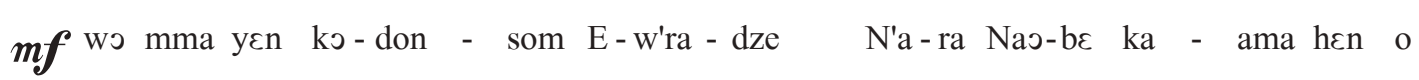

B 2

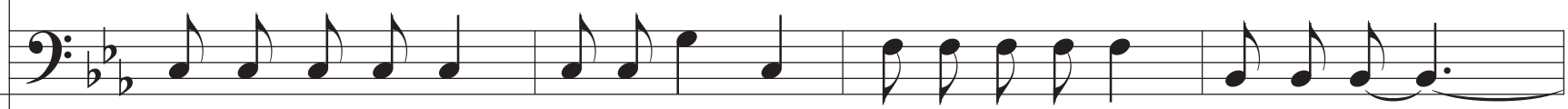

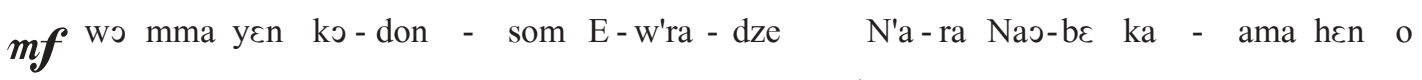

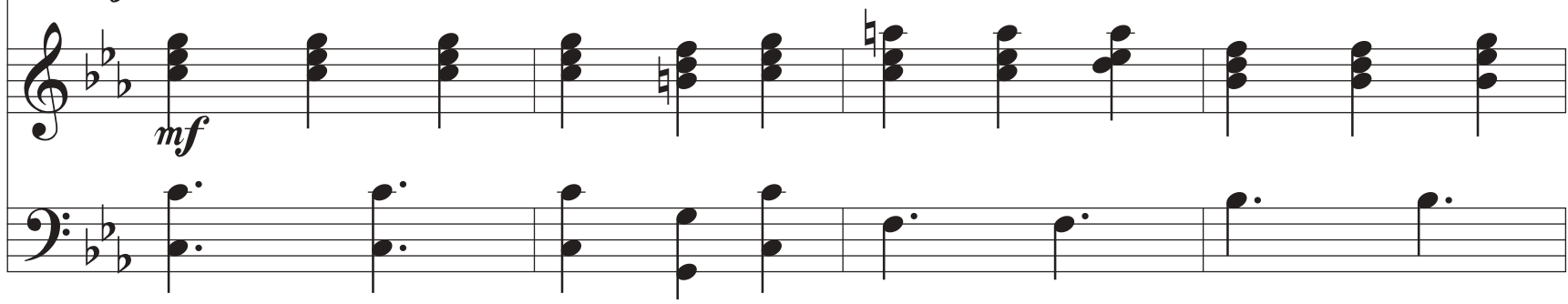

Voice Solo with Piano and Choruses for T.T.B.B | 46 


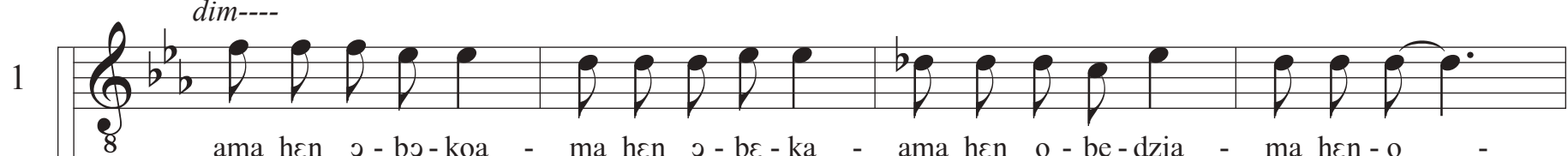

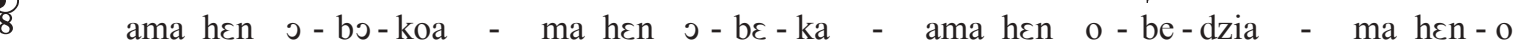

T 2

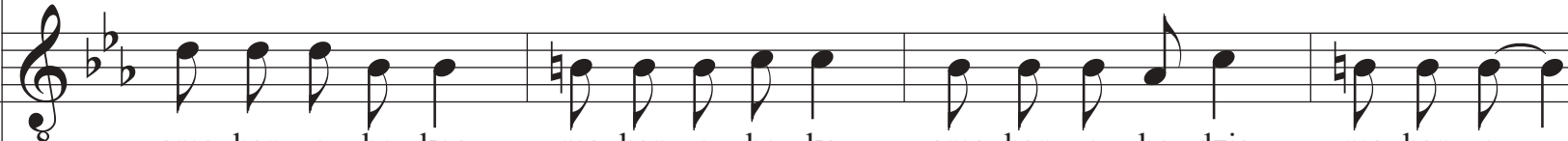

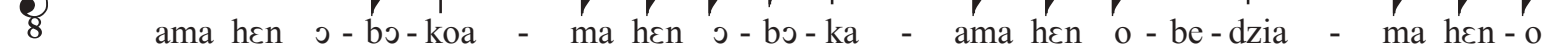

B 1

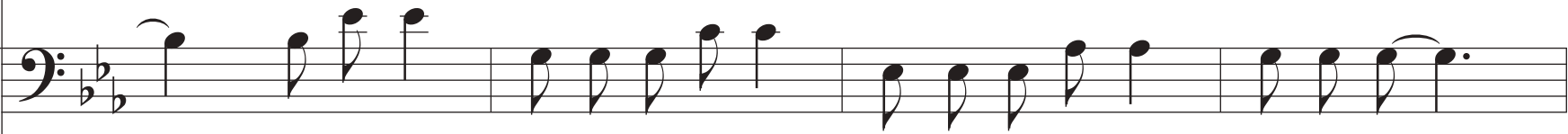

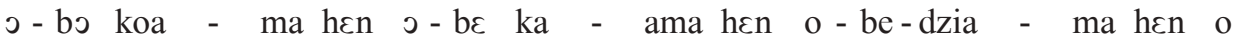

B 2

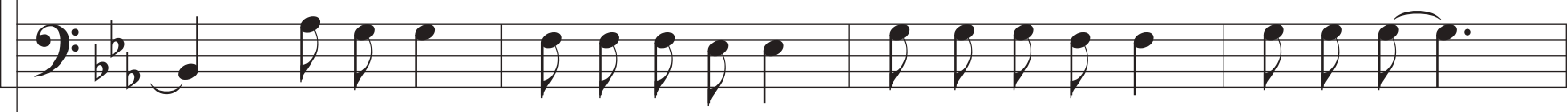

э - bə koa - ma hen ว - be ka - ama hen o - be-dzia - ma hen o
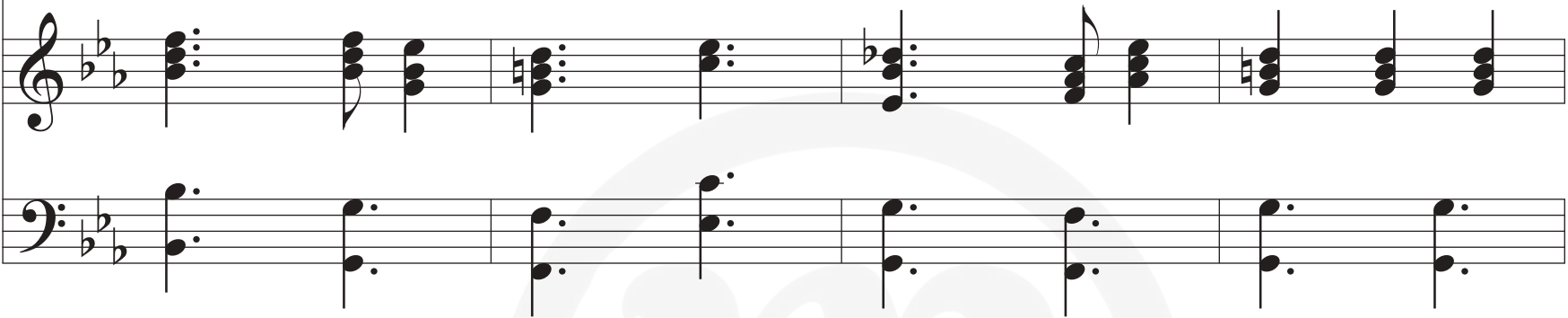

T 1

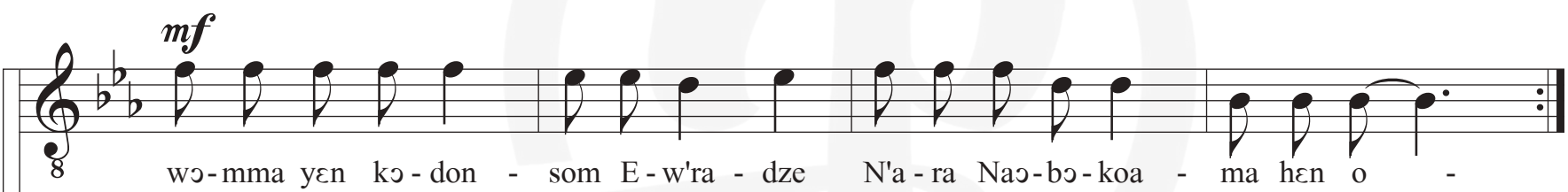

T 2

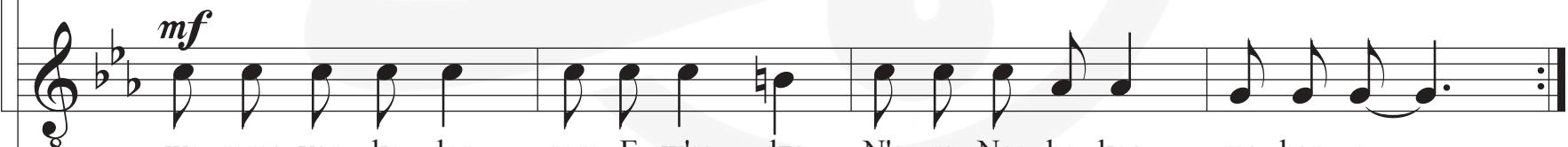

8 wo-mma yєn ko-don - som E-w'ra - dze N'a-ra Naว-bっ-koa - ma hєn o

B 1
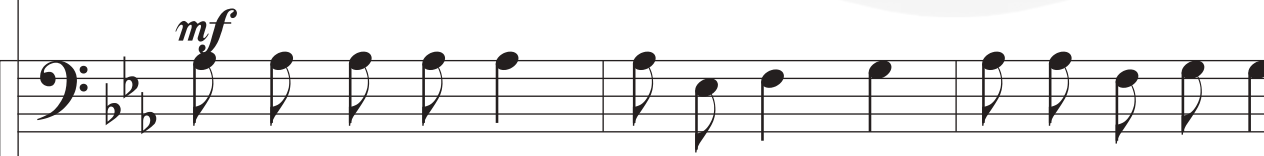

wo-mma yen ko don - som E-w'ra - dze N'a-ra Naっ-bっ-koa - ma hen o

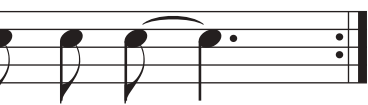

B 2

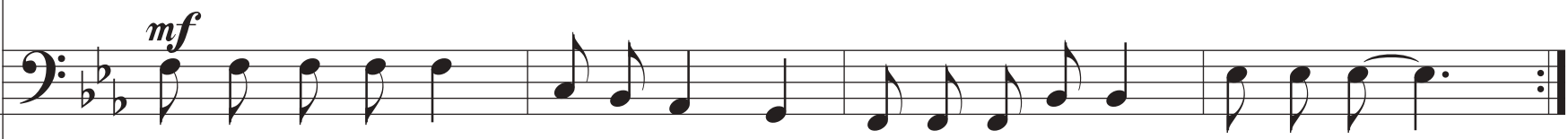

wっ-mma yєn kə don - som E-w'ra - dze N'a-ra Naっ-bっ-koa - ma hєn o

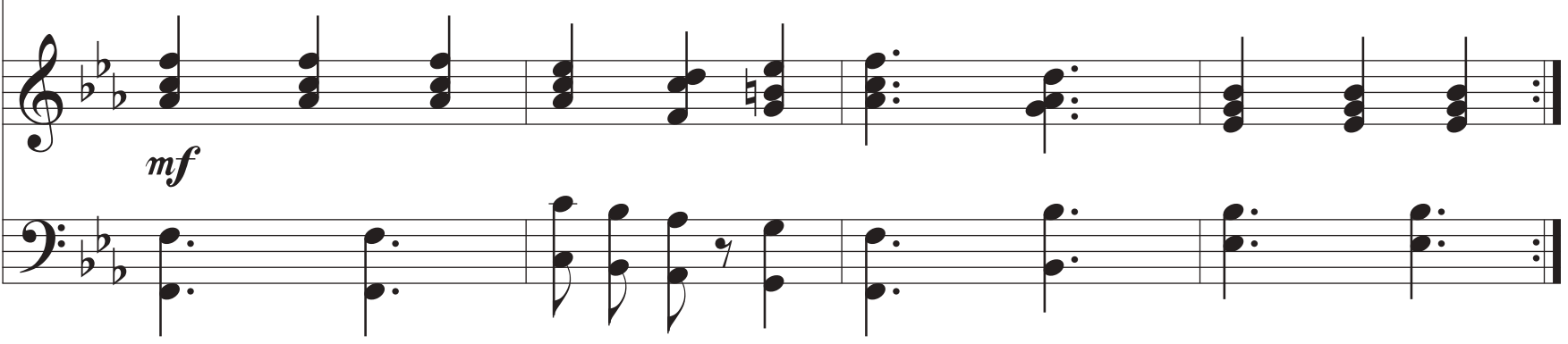

Voice Solo with Piano and Choruses for T.T.B.B 
T 1

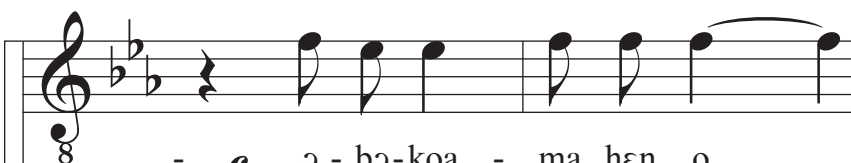
- $\boldsymbol{m} \boldsymbol{f}$ o-bo-koa - ma hen o

ว - be ka - ama hen o

T 2

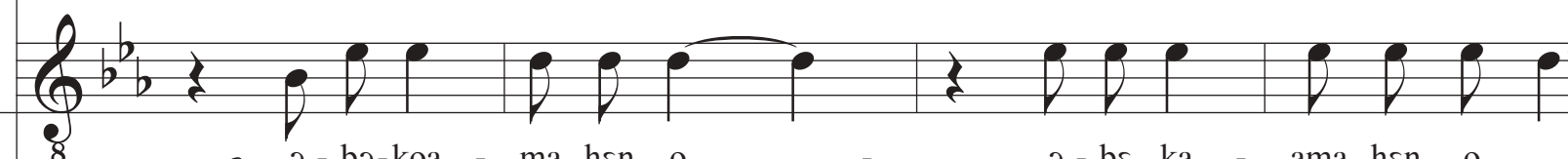

$$
\boldsymbol{m} \boldsymbol{f} \text { o-bo-koa - ma hen o }
$$

o - be ka - ama hen o

B 1

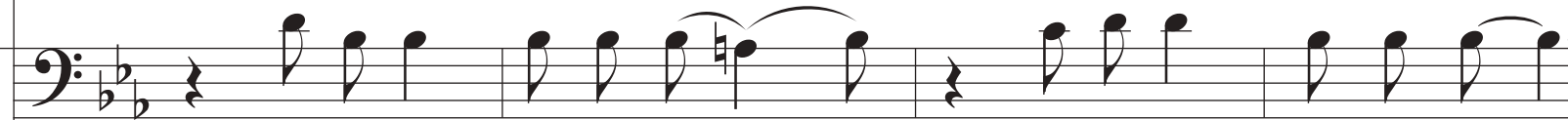

$$
m f
$$

B 2
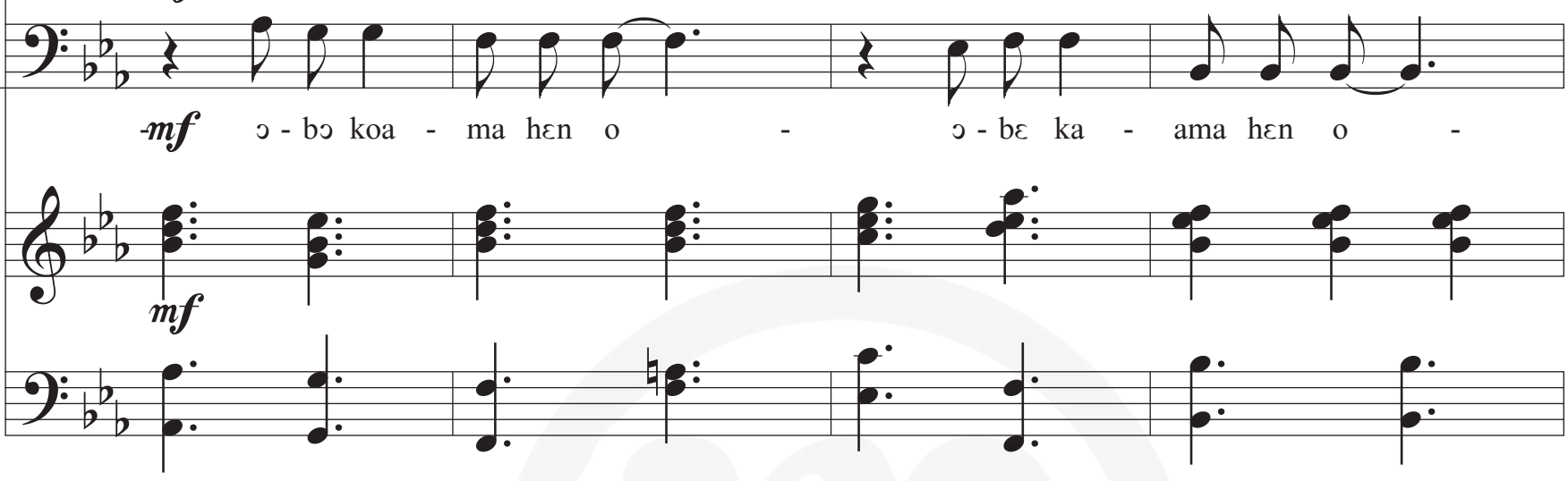

$\mathrm{T} 1$

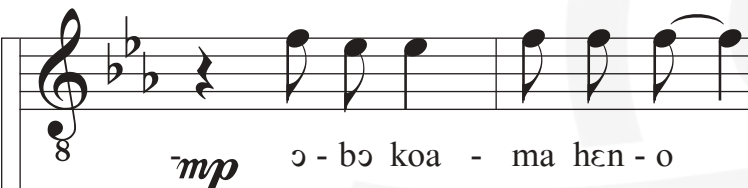

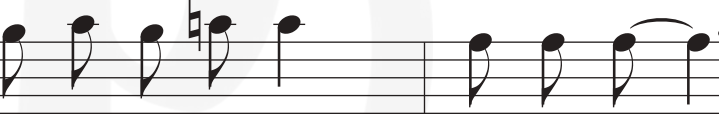

$$
\text { mp o-bok }
$$

T 2

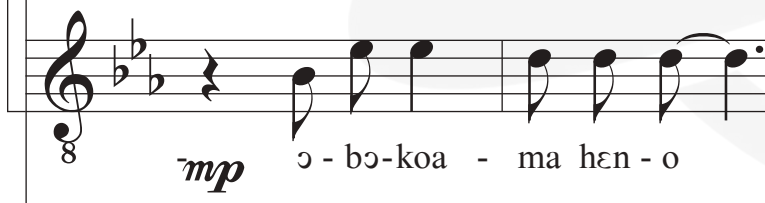

Nya-me $\mathrm{O}-$ be-dzia

ma-hen o -

B 1

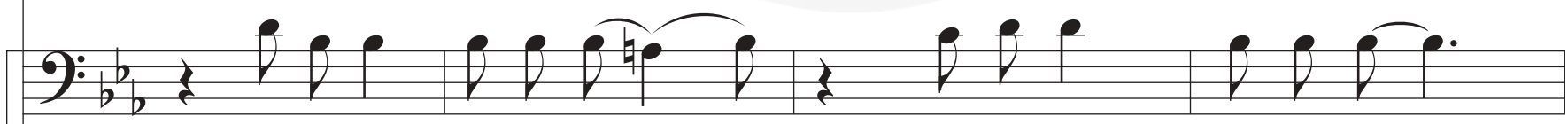

$$
{ }^{-} \boldsymbol{m p} \text { o- bo koa - ma hen o }
$$

O - be - dzia

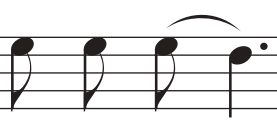

Nya-me O-be-dzia - ma hen o

B 2
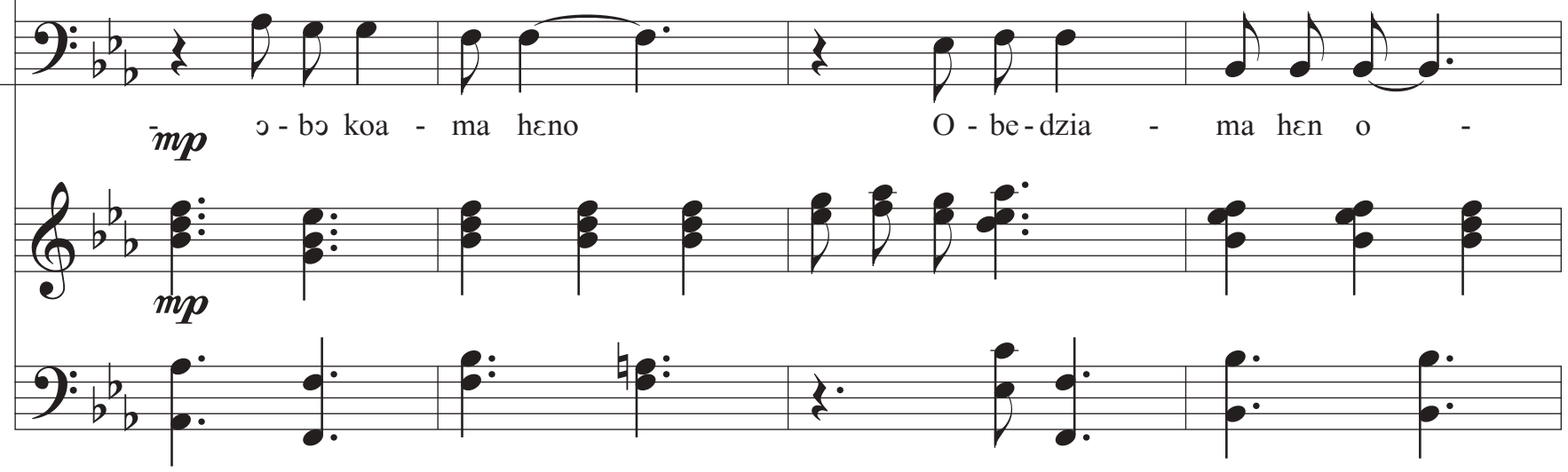
$\mathrm{T} 1$

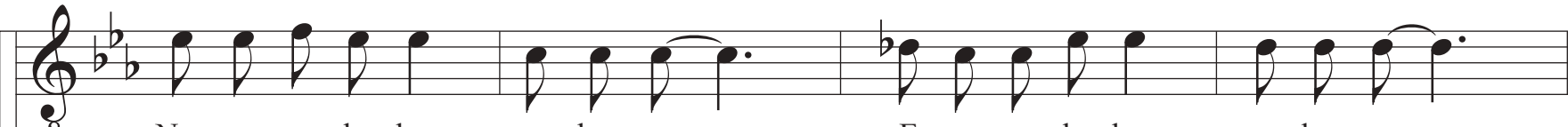

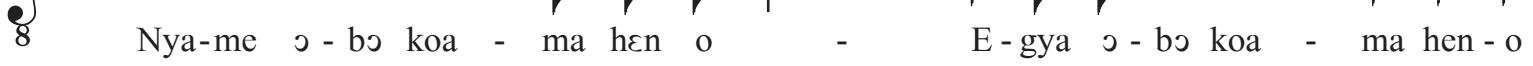

T 2

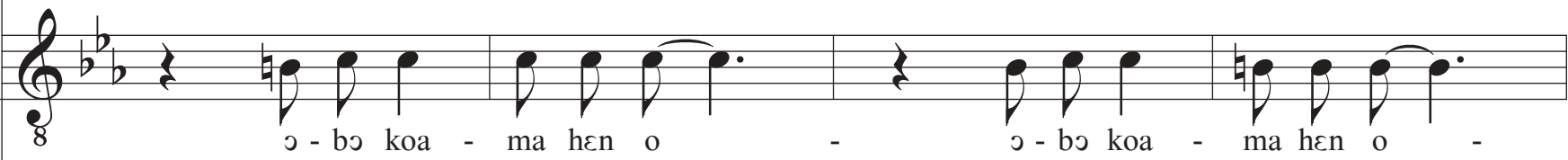

B 1

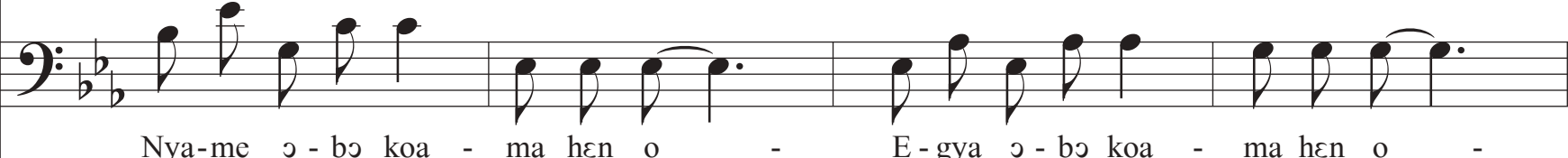

B 2
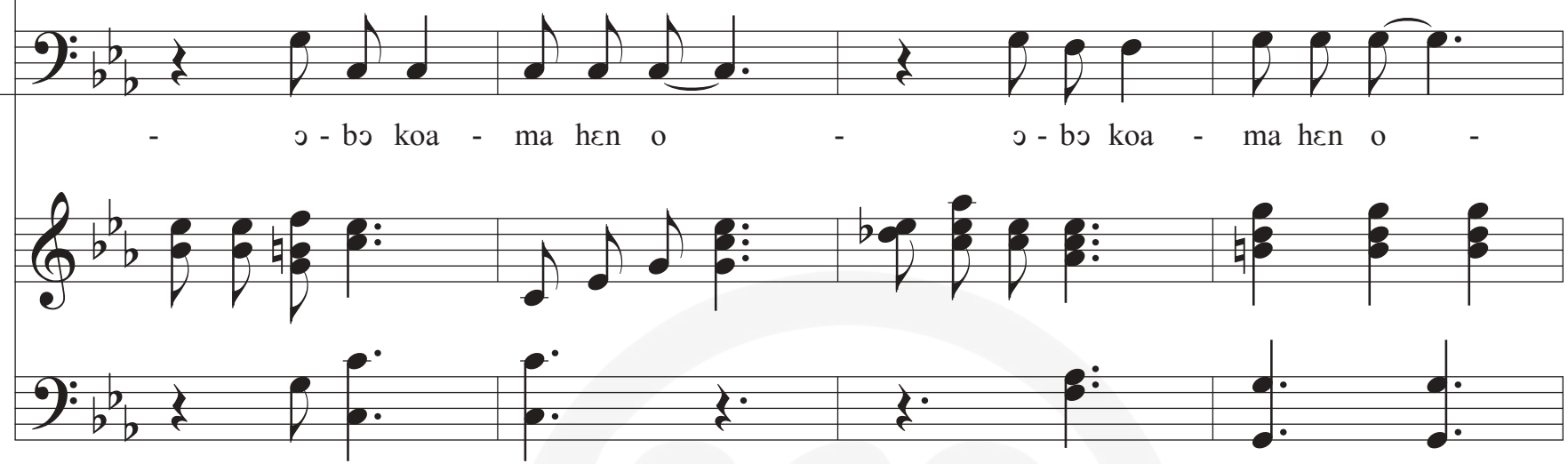

T 1

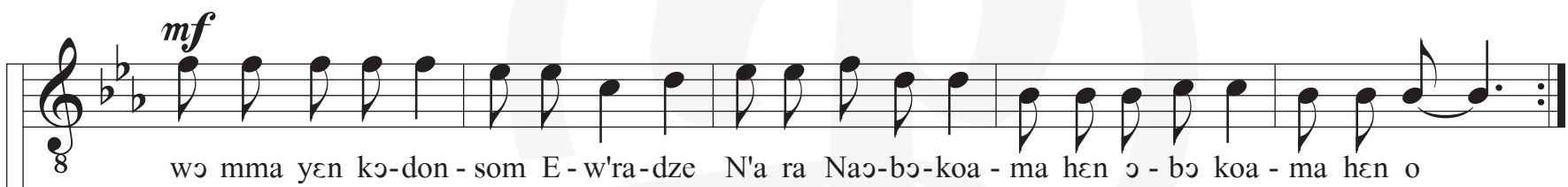

T 2

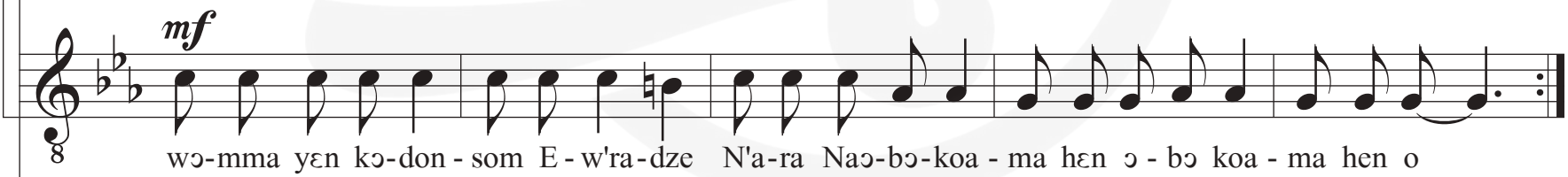

$$
\text { mf }
$$

B 1

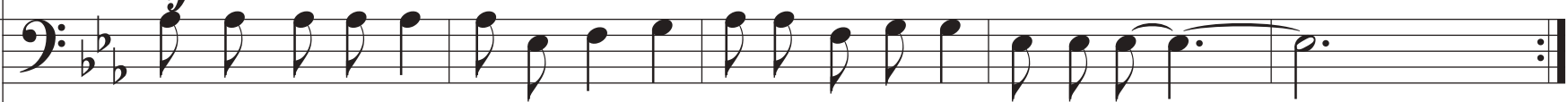

wo mma yen kə-don-som E-w'ra-dze N'a-ra Naэ-bっ-koa-ma hen o

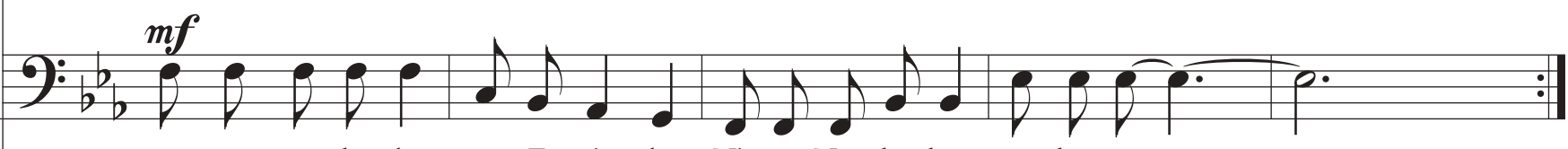

wo mma yєn kə-don-som E-w'ra-dze N'a-ra Naэ-bっ-koa-ma hen o

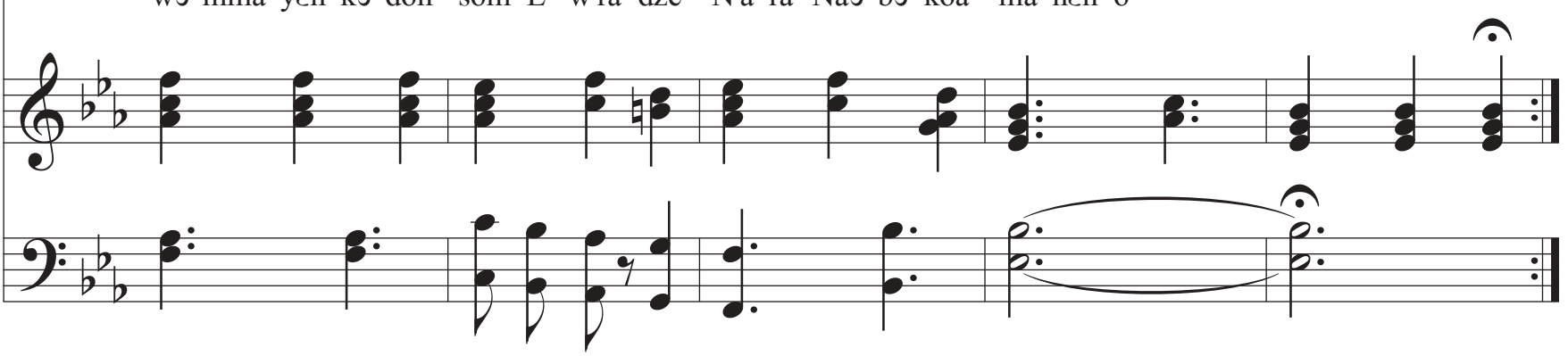




\section{BONE BEN \\ (What Crime)}
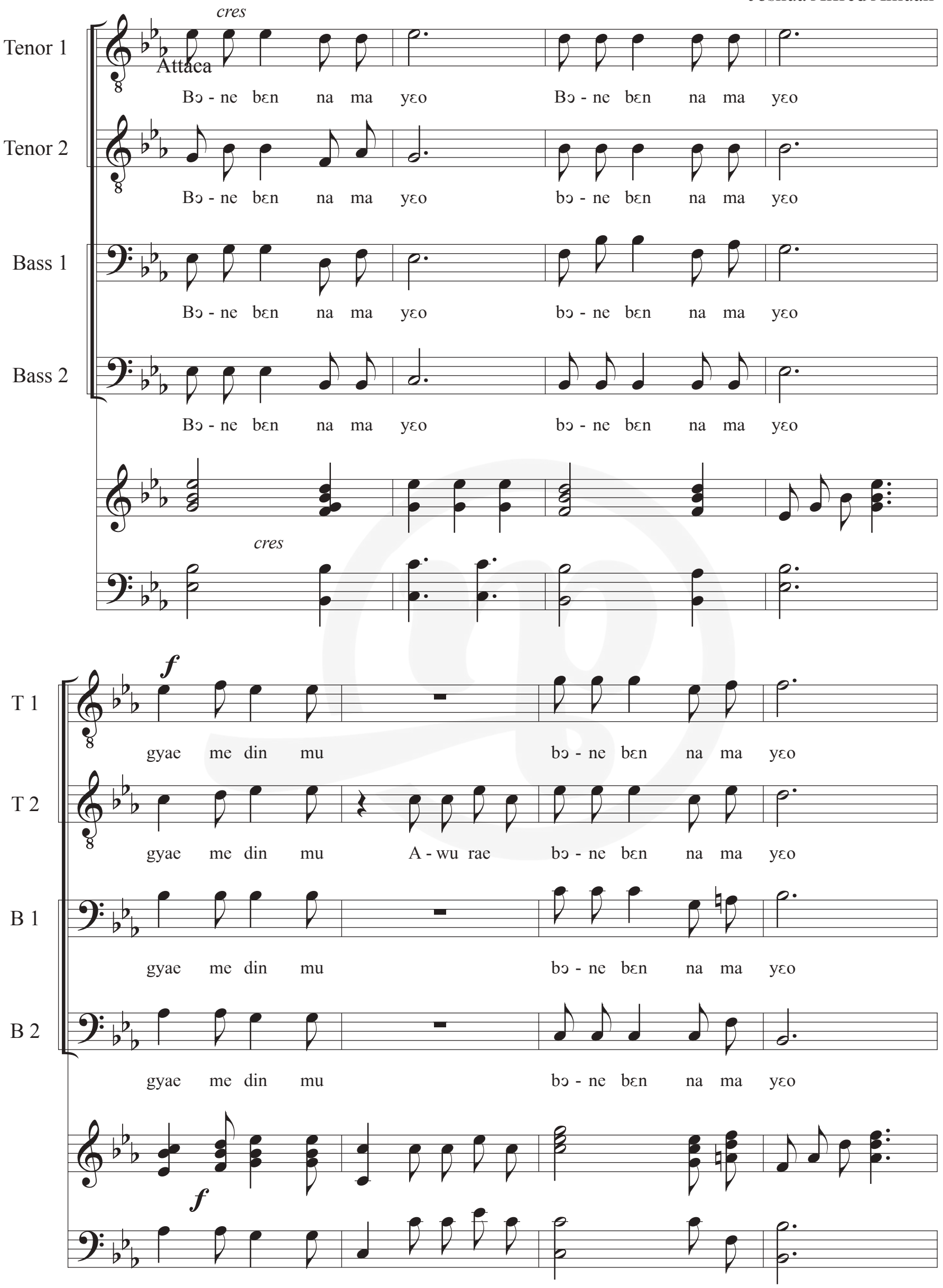

Voice Solo with Piano and Choruses for T.T.B.B | 50 
T 1

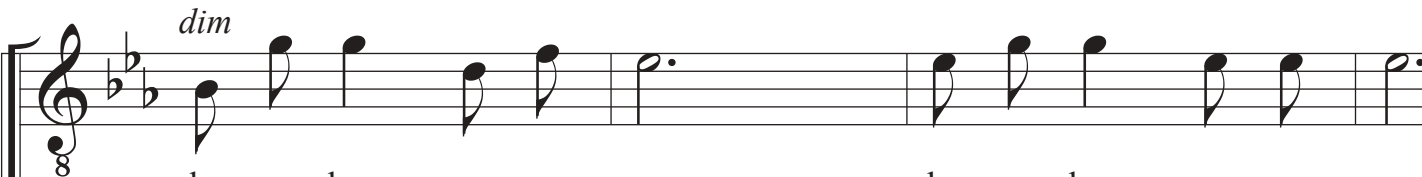

T 2

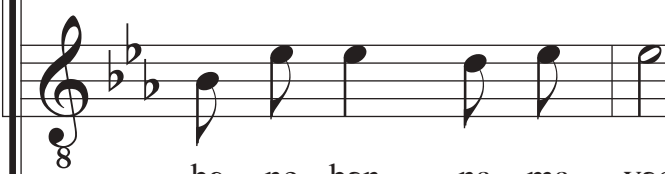

B 1 bo - ne ben na ma yєo

bo - ne ben na ma yeo

B 1
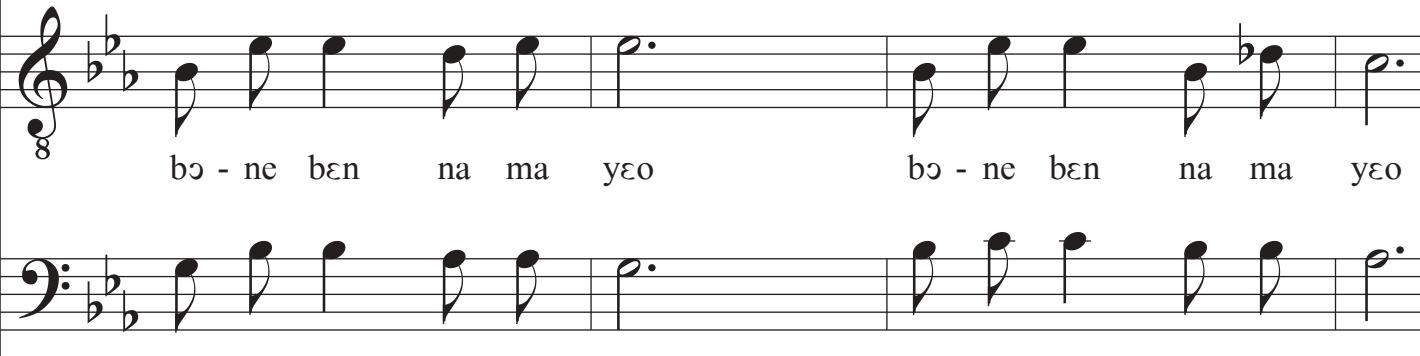

$$
\text { bo - ne ben na ma yєo }
$$

bo - ne ben na ma yعo

B 2

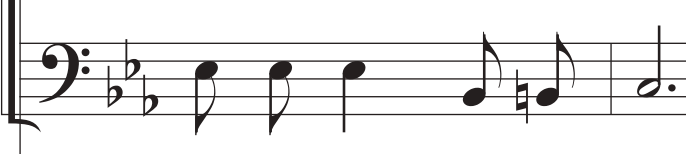

$$
\text { bэ - ne ben na ma yєo }
$$

bo - ne ben na ma yєo

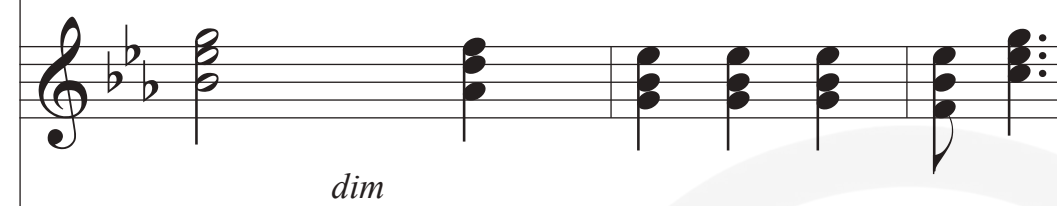

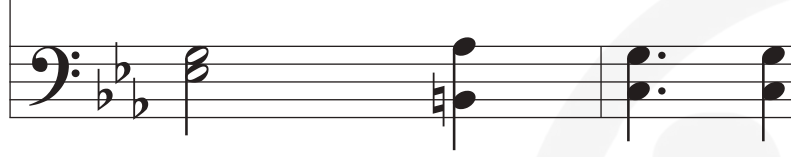
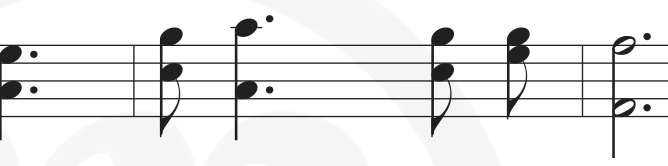

$\mathrm{T} 1$

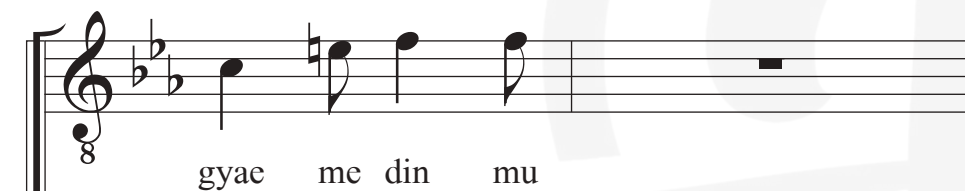

gyae me din mu

Bэ - ne bєn
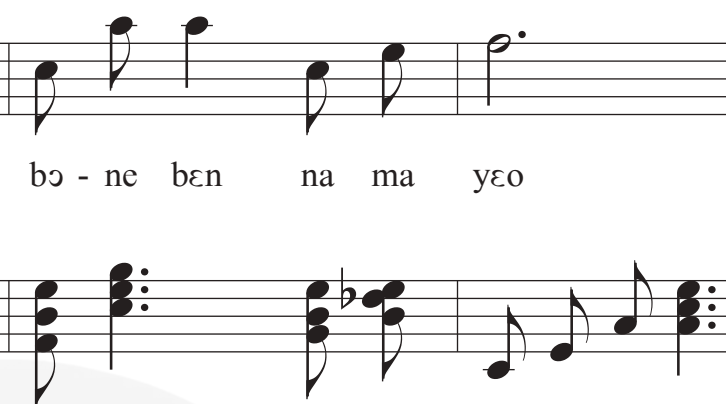

T 2

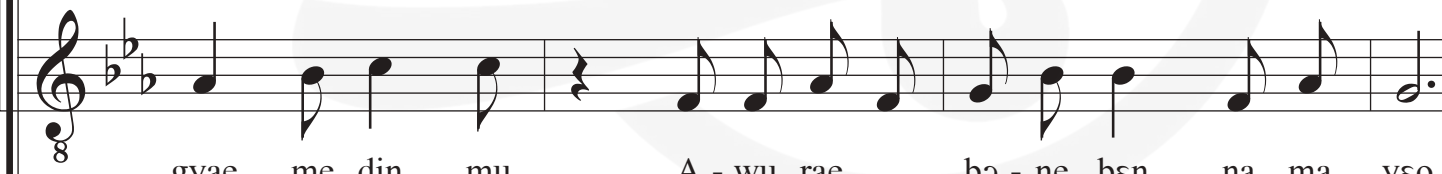

B 1

gyae me din mu

A - wu rae

bo - ne ben

na ma yєo

B 2

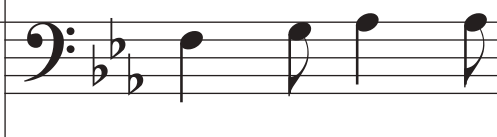

gyae me din mu
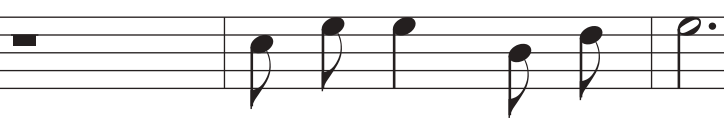

bo - ne ben na ma уєо

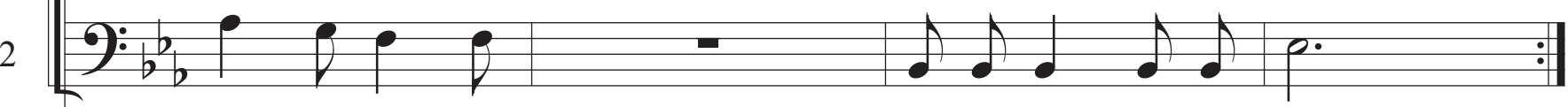

gyae me din mu

bo - ne bєn na ma уєо

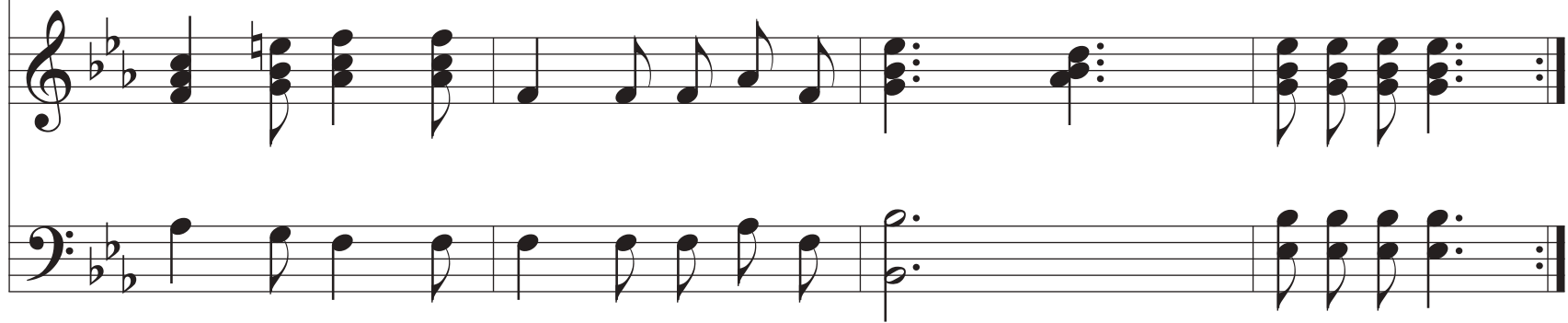

Voice Solo with Piano and Choruses for T.T.B.B | 51 
T 1

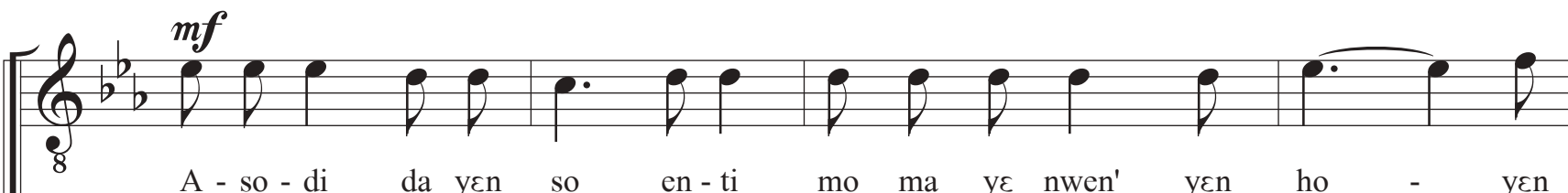

T 2

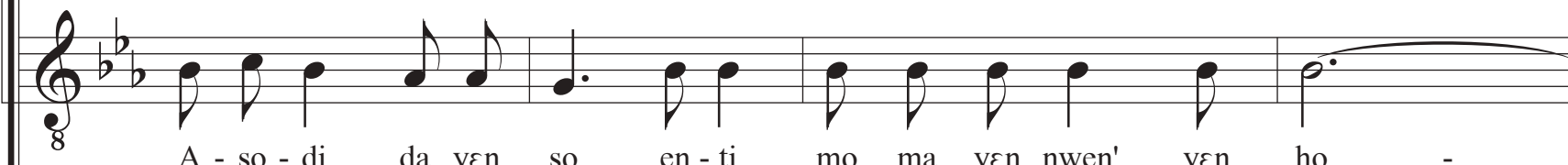

B 1

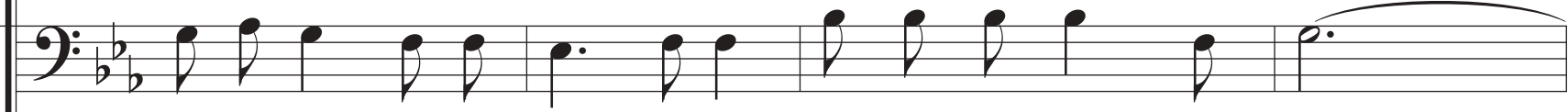
A - so - di
da yen so
en - ti
mo ma yen nwen'
yen ho

B 2

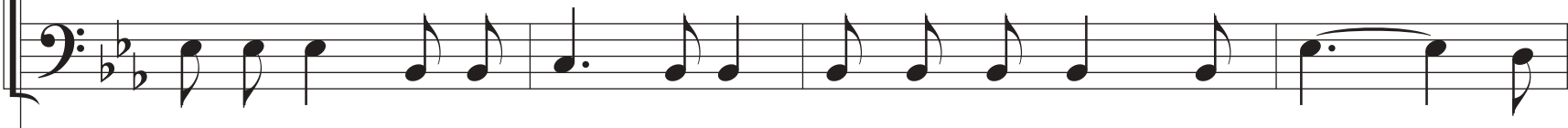

A - so - di da yen so en-ti mo ma yen nwen' yen ho - ye

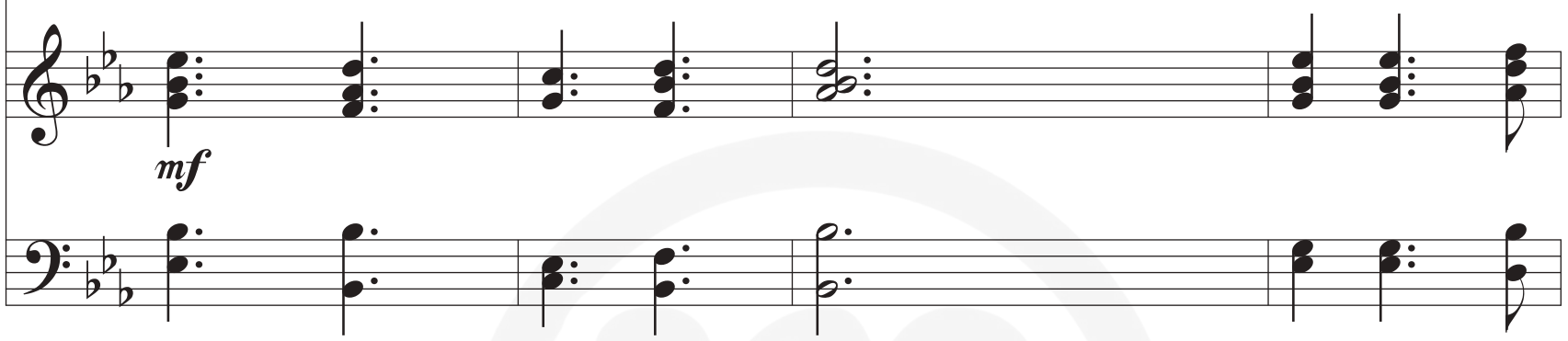

$\mathrm{T} 2$

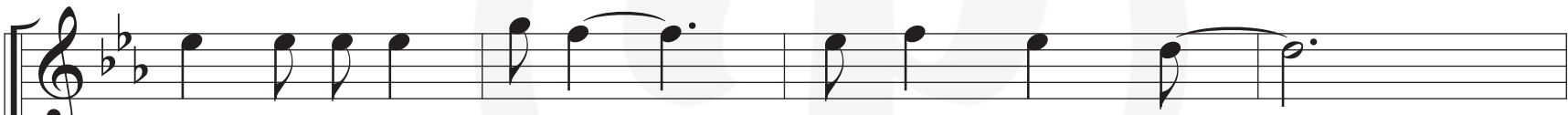
8 ho a - ke - ka - ake-kai $\quad$ cm - fa hwee mmao

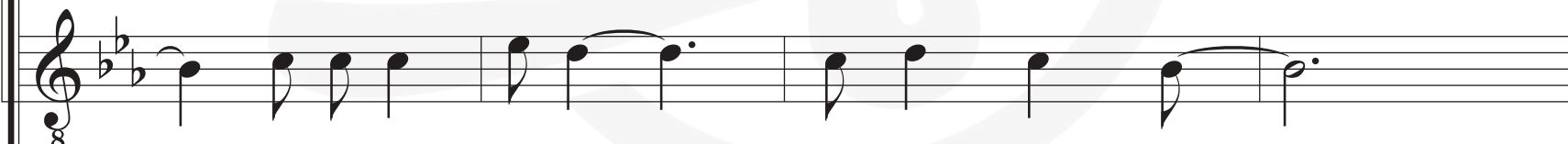

B 1

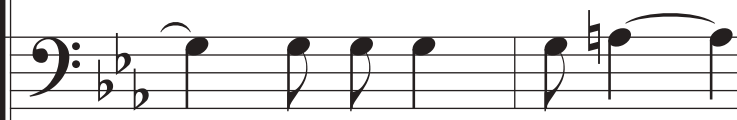

B 2
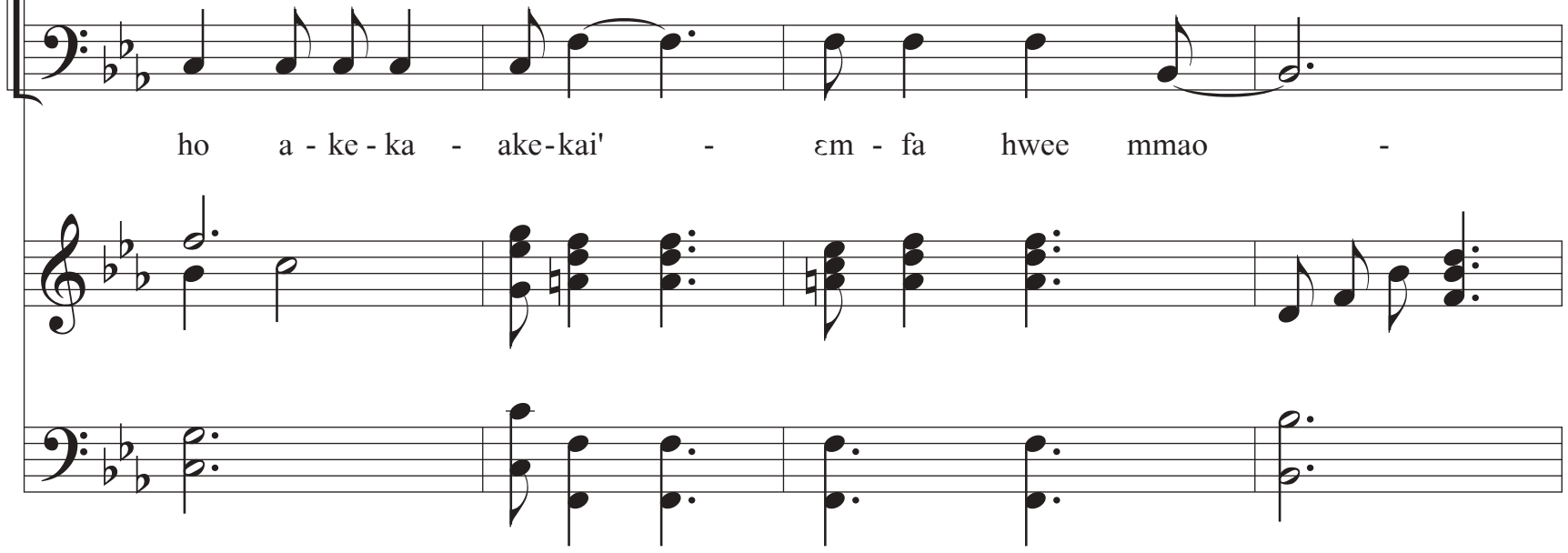

Voice Solo with Piano and Choruses for T.T.B.B | 52 
$\mathrm{T} 1$

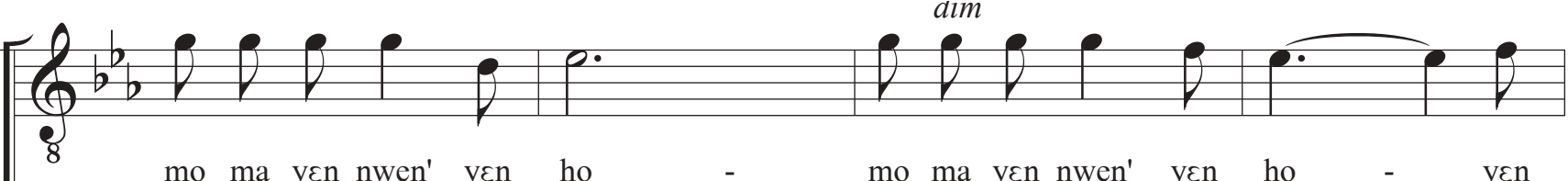

T 2

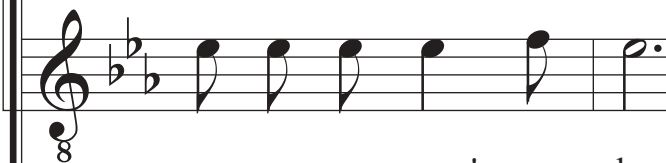

mo ma yen nwen' yen ho

yعn

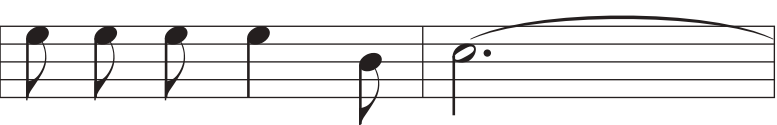

B 1

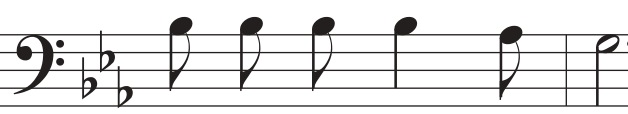

mo ma yєn nwen' yєn ho

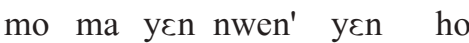

mo ma yen nwen' yen ho

B 2

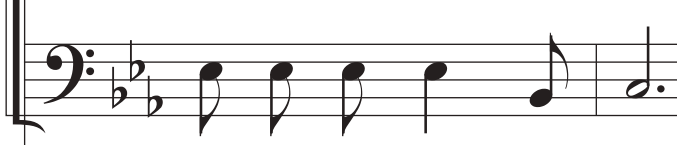

mo ma yen nwen' yen ho
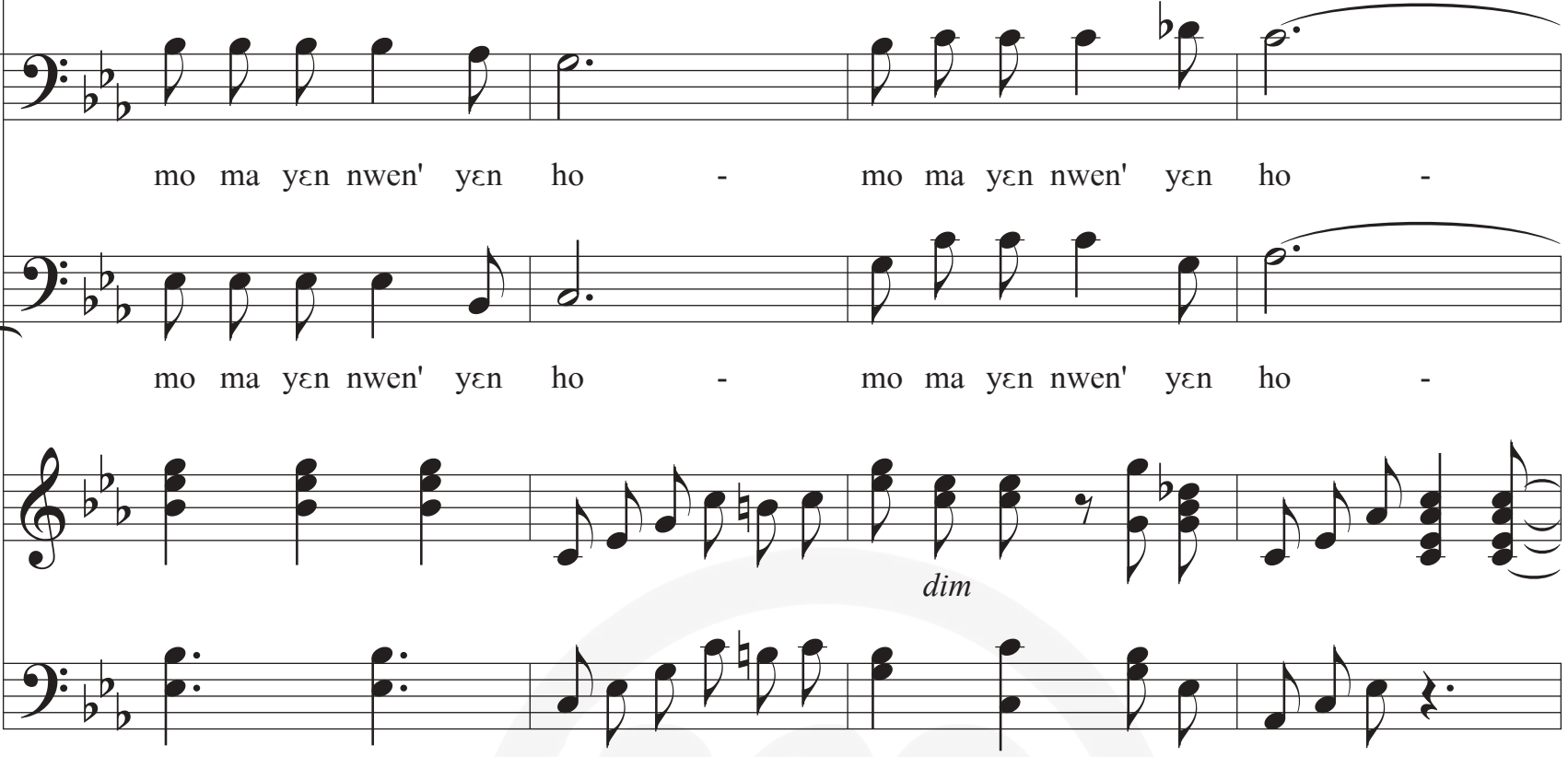

T 2

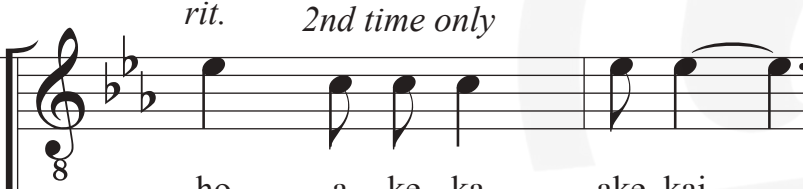

ho a - ke-ka - ake-kai

हm - fa hwee mmao - .

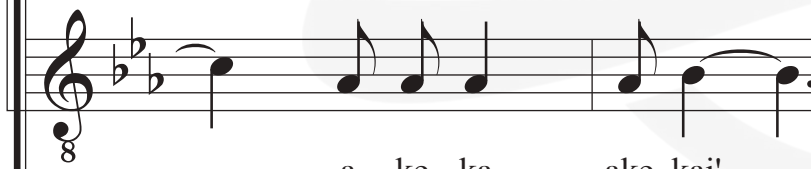

lop?

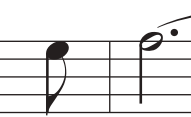

$\mathrm{T} 1$

B 1

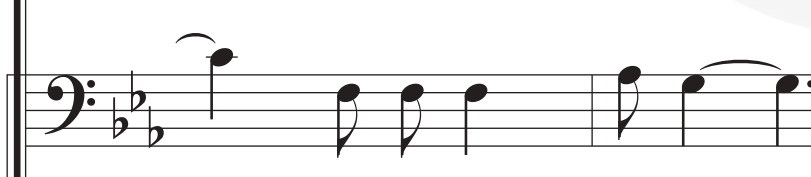

a - ke-ka - ake-kai _ $\quad$ em - fa hwee mmao-.

B 2

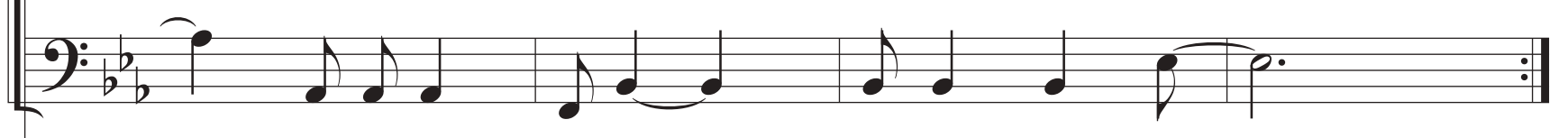
a - ke - ka - ake-kai'
हm - fa hwee mmao - .
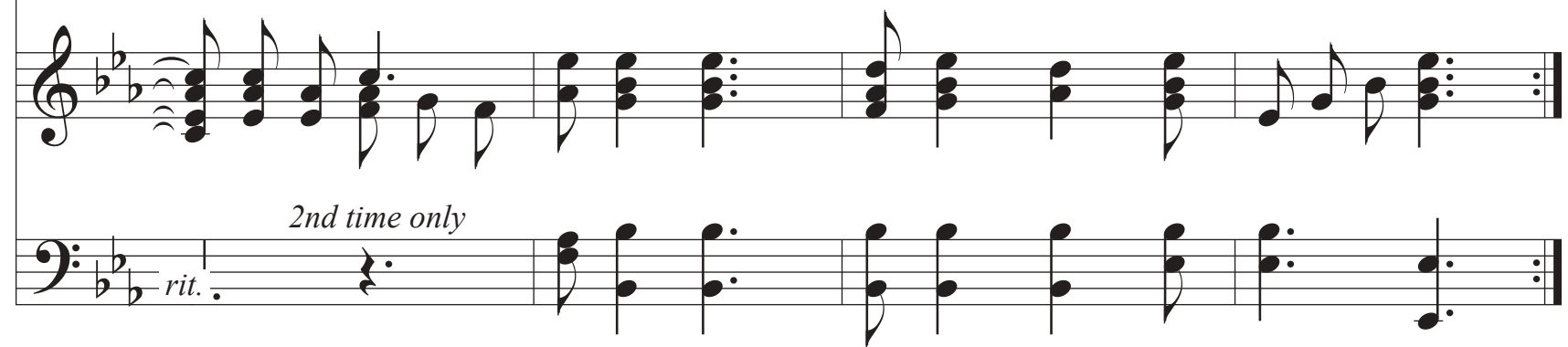

Voice Solo with Piano and Choruses for T.T.B.B | 53 


\section{THIS COPY IS NOT FOR SALE}

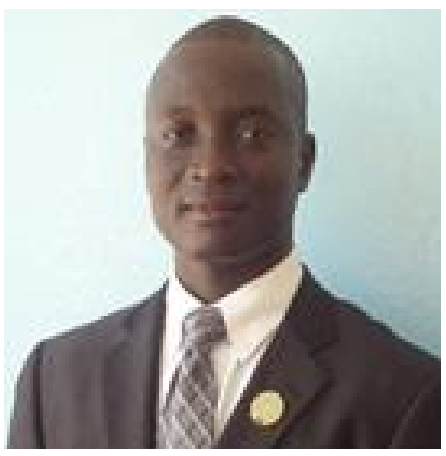

\section{ABOUT AUTHOR}

Joshua Alfred Amuah is a currently Senior Lecturer in the Department of $\mathrm{Mu}-$ sic, School of Performing Arts, University of Ghana, Legon. He holds a Ph.D. in Music, from the University of Ghana, Legon and University of Rochester, NY, USA, M. Phil in Music Theory and Composition from University of Ghana, Legon, Bachelor of Education in Music and Ghanaian Language (Akan) and a Diploma in Music Education, from University of Education, Winneba.

He teaches Music Theory and Composition and other related courses to undergraduate and postgraduate students at the Department of Music, University of Ghana, Legon and is actively involved in Choral Directing and Adjudication throughout Ghana. With a teaching credential in Music Theory from the University of Ghana, he takes interest in the choral music composition using traditional music elements in contemporary Ghana. His research interest also spans a blend of indigenous and Western choral music compositional trends, which are utilized in the church.

He has written a number of books on Rudiments and Theory of Music for use of Senior High Schools, Colleges of Education and Universities. Within the last few years, Joshua has come out with two anthologies: Songs for Christmas, composed by Ghanaians and Passion pieces suitable for rendition during Palm Sunday, Good Friday and Easter Sunday.

He belongs to professional bodies of music including the American Choral Directors Association (ACDA), Ghana Music Teachers Association, (GMTA), Society for Ethnomusicology (SEM), Association of Methodist Church Choirs where he served as the National 1st Deputy Director of Music. He is also a member of the Pan African Society for Musical Arts Education (PASMAE).

To his credit, he won the first prize award of the Trades Union Congress (TUC) Ghana anthem composition contest in 1995. 